\title{
MEASURING REAL ECONOMIC EFFECTS OF BAILOUTS: HISTORICAL PERSPECTIVES ON HOW COUNTRIES IN FINANCIAL DISTRESS HAVE FARED WITH AND WITHOUT BAILOUTS
}

\author{
Michael Bordo \\ Anna J. Schwartz \\ Working Paper 7701 \\ http://www.nber.org/papers/w7701 \\ NATIONAL BUREAU OF ECONOMIC RESEARCH \\ 1050 Massachusetts Avenue \\ Cambridge, MA 02138 \\ May 2000
}

Paper prepared for the Carnegie Rochester Conference on Public Policy November 19-20, 1999. For extremely valuable research assistance and econometric advice we thank Debajyoti Chakrabarty and Elena Goldman. For providing us with data we thank Jim Boughton and Tam Bayoumi of the IMF. For useful comments, we thank Jim Boughton, Mohsin Khan, Bennett McCallum, and Bob Rasche. The views expressed herein are those of the authors and not necessarily those of then National Bureau of Economic Research.

(C)2000 by Michael D. Bordo and Anna J. Schwartz. All rights reserved. Short sections of text, not to exceed two paragraphs, may be quoted without explicit permission provided that full credit, including (C) notice, is given to the source. 
Measuring Real Economic Effects of Bailouts: Historical Perspectives on How

Countries in Financial Distress Have Fared With and Without Bailouts

Michael D. Bordo and Anna J. Schwartz

NBER Working Paper No. 7701

May 2000

JEL No. F3, G2

\section{$\underline{\text { ABSTRACT }}$}

In this paper we first trace the changing nature of banking, currency and debt crises from the last century to the present. Each type of crisis has transmogrified in the presence of official intervention and the creation of a safety net. A similar pattern is observed for international rescue loans. We then present evidence suggesting that the incidence has increased and the severity of financial crises has changed little in emerging markets from the pre-1914 era to the present. Finally we assess the impact of IMP loans on the macro performance of the recipients. A simple with-without comparison of countries receiving IMF assistance during crises in the period 1973-98 with countries in the same region not receiving assistance suggests that the real performance of the former group was possibly worse than the latter. Similar results obtain adjusting for self-selection bias and counterfactual policies.

Michael D. Bordo

Department of Economics

Rutgers University

New Brunswick, New Jersey 08901-1284

(732) 932-7416

and NBER

bordo@fas-econ.rutgers.edu
Anna J. Schwartz

National Bureau of Economic Research

365 Fifth Avenue, $5^{\text {th }}$ Floor

New York, New York 10016-4309

(212) 817-7957

aschwartz@gc.cuny.edu 


\section{Introduction}

Bailouts of countries in financial distress have been a phenomenon of the 1990s. Unlike bailouts, rescue loans of countries in financial distress have had a long history. Recent research compares various dimensions of bailouts and rescues: who were the agents of these international loans, and what were the conditions under which they offered aid. In this paper we propose to study evidence of the post-loan experience of the borrowers.

One question of interest to us is the effect of loans, whether bailouts or rescues, on the borrowers' per capita real incomes, interest rates, inflation rates and other macro aggregates. The IMF and independent research workers have also explored the post-loan experience of borrowers. Our objective, however, is more ambitious. We want to address the question whether it is possible to differentiate effects in countries in distress that obtained bailouts or rescue loans from effects in the absence of loans in other countries also experiencing financial distress. We examine a sample of countries that includes not only those that borrowed but also those that did not.

There are many difficulties in assessing the effect of lending on the outcomes in the economies under investigation. In order to isolate a link with loans, it is necessary to observe ceteris paribus. The record of countries emerging from an episode of financial distress may reflect not only the presence or absence of international lending but also other factors. Countries may differ in respect of the competence of their governments, the stability of political arrangements, the existence of safety net institutions, to name a few obvious things other than international lending that can influence outcomes. So it is hard to tell if the outcomes are related to lending or to some other factor. The paper attempts to deal with these complications.

In section 2, we define terms. We distinguish between a financial panic and a financial crisis, and between a rescue loan and a bailout. Financial crises include banking, debt, and 
currency crises. Banking crises were either banking panics or banking collapses. A debt crisis is a type of historically recurrent financial crisis, in which sovereign nations or private sector companies are unable to service borrowings from foreign lenders. Pre-1914, private workouts renegotiated the terms of the loans. Since the 1980s, governments and international lending agencies have intervened in micromanaging workouts. Currency crises occur when the pegged foreign exchange value of a currency is subject to a speculative attack.

We review lending in a variety of financial crises. These include lender-of- last resort lending in cases of domestic banking crises, initially conceived as administered on Bagehot's principles, modified in recent episodes to justify lending to large institutions regardless of solvency, on the principle of too big to fail. We contrast lender-of-last-resort provision of liquidity with current fiscal resolution of banking crises. We then define international lending, beginning with currency crises that pre-1914 was extended by central banks on commercial terms to a central bank facing a shortage of international reserves. This loan type evolved postWorld War II into official lending to monetary authorities by the IMF and other international bodies, and in the 1990s to bailouts. The US Exchange Stabilization Fund played a crucial role in the transition to the current style of package loans and bailouts.

In section 3, we review the stages by which banking, debt, and currency crises have evolved from their past to present manifestations.

In section 4 we review the historical stages by which international lending in crises has evolved into its present forms. These include rescue loans, bailouts, and guaranteed loans from the pre-1914 era to today. For the interwar period, we cover subsidized stabilization loans to European central banks, debt relief to Germany, and ESF loans to Latin-American and other countries of political importance to the US. Post-World War II, we cover subsidized lending by US agencies, like the Export-Import Bank; IMF stabilization packages; the arrangements to solve 
the debt crisis of the 1980s; Chile's 1980s government cross-border loan guarantees; 1990s bailouts to protect US and European bank creditors; and estimates of size of subsidy in1990s IMF bailout packages.

In section 5, we discuss evidence on the incidence and severity of crises over the past century. This evidence suggests that the crisis problem for emerging market countries has still not been resolved.

In section 6, we present a chronology limited to Latin-American and Southeast Asian countries in financial distress that obtained IMF packages in 1973-98, showing the aggregate amounts of IMF loans from various facilities, and the amounts from other lenders. We describe the patterns the chronology reveals, principally, the presence of a number of countries who receive IMF assistance continually over many years and the enormous size of bailouts beginning with the Mexican case in 1995 compared to the earlier rescue loans.

We then present figures which show the behavior of salient macro variables in a window five years before, during, and five years after crises. We do this for countries in financial distress that obtained IMF and other assistance and for others that did not in the period 1973-1999. We also distinguish between the experience of Latin America and Asia.

In section 7 we discuss difficulties raised by a simple side-by-side comparison of countries receiving and those not receiving assistance. The issue is to establish a reasonable counterfactual against which to make the comparison. Such a counterfactual needs to take into account the different preconditions facing the two sets of countries and changes in the environment during the crisis window. Two issues to be addressed are the policies that would be followed in the counterfactual world absent the IMF and the self-selection bias that differentiates countries that turn to the IMF from those that do not. To deal with these issues we use a two-step procedure, 
developed by Khan (1990) and Conway (1994), to isolate the economic impact of an IMF stabilization package.

We conclude with policy lessons in section 8.

\section{Some definitions}

Financial crises have occurred under varying monetary regimes. A financial crisis differs from a financial panic. A financial panic occurs in the money market and is a threat to the economy's payments system. A panic can be quickly ended by a lender of last resort. The recent difficulties of emerging market countries have involved financial crises rather than financial panics. A financial crisis occurs when asset prices plunge, whether prices of equities, real estate, or commodities; when the exchange value of a national currency experiences substantial depreciation; when a large financial or nonfinancial firm or an industry faces bankruptcy, or a sovereign debtor defaults. A financial crisis is a prolonged disturbance that is resolved by government agencies other than the lender of last resort, although at some stage the lender of last resort may provide liquidity to the market through the discount window or open market purchases (Schwartz 1986; Bordo, Mizrach, and Schwartz 1998).

A financial crisis arose under the pre-World War I gold standard, when either the banking system or the domestic currency or both experienced strains. Such strains were commonly described as internal and external drains. A banking panic was an example of an internal drain. Depositors who lost confidence in their banks' ability to convert deposits into currency would run the banks, draining them of high-powered money. A currency crisis was an example of an external drain. Holders of the domestic currency who lost confidence in its exchange value would attempt to convert it into gold or foreign currencies, draining monetary authorities of their international reserves. 
Until the 1980s, international lending to assist a country facing a currency crisis had the character of a rescue loan. A foreign lender provided foreign exchange to monetary authorities sufficient to cover a shortfall in the current account or to service debt. The foreign lender was a central bank or a syndicate of private investment houses. Beginning in the 1930s, the foreign lender was the US Treasury Exchange Stabilization Fund (ESF) and, after World War II, the ESF plus other US and international agencies. A rescue loan may be defined as the provision of foreign exchange by an international lender to monetary authorities sufficient to cover a shortfall in means to meet current obligations on external account. A rescue loan did not provide funds for extinguishing foreign debt.

More recently, bailouts have characterized international lending. A bailout applied to currency crises is a big-enough loan so that a borrower can reimburse investors for interest and principal due on foreign capital on which the monetary authorities would otherwise default. In the generic sense of a bailout, the lender suffers no or minimum loss.

\section{Historical perspective on the evolution of financial crises}

The objective of this section is to review how the initial delineation of the financial crises that we examine was transformed over time into a different type. The categories of financial crises include banking crises, debt crises, currency crises, and combinations of two or more of the categories. We discuss the transformation of each category of financial crises over time

\section{$3.1 \quad$ Evolution of banking crises}

Bank failures have occurred over the centuries under many monetary regimes in both advanced and emerging market countries, more often in a unit banking system than in one with few banks with many branches. An individual bank failure was no more threatening to the health of an economy than the failure of an individual commercial company, and was a less frequent 
occurrence. An individual bank failure was usually the result of fraud, defalcation, or

embezzlement, and the market recognized that this was not a problem of the banking system as a whole.

The case was different if a banking panic occurred. Then the attempt by depositors to withdraw their funds in cash from banks in general and the attempt by the banks to augment their reserves could shut down the payments system, freezing the ability of the banks to extend loans and the ability of holders of claims on depositors to collect what was owed. It was the experience of these circumstances that taught central banks that an injection of liquidity was essential to relieve panic conditions. Under the gold standard a central bank could inject liquidity only if it had adequate gold reserves and was responsive to a panic-created dearth of funds in financial markets. The dilemma facing a central bank under the gold standard, whether to protect its own gold reserves or to lend them freely when panics arose, does not exist under a fiat money regime.

What is unchanged no matter which monetary regime is in operation is the decision on the method of injecting liquidity: through the discount window directed to particular banks or through open market operations directed to the market to allocate among banks in need of highpowered money. A unique feature of British financial organization was the existence of discount houses at which commercial banks could cash good bills. If the discount houses needed cash, they could turn to the Bank of England with these bills and have them discounted. This was ordinary banking business and did not imply lender of last resort services. ${ }^{1}$ Only during panics

\footnotetext{
${ }^{1}$ According to Capie (1999), the Bank of England lent on an impersonal basis. Eligible securities were passed to the Bank under a frosted glass window. In the US, under the Federal Reserve, member banks could discount eligible collateral. This set the stage for discount window lending in crisis.
} 
were these services required. The money market recovered promptly as soon as the central bank provided the liquidity that the market lacked. ${ }^{2}$

In emerging market countries a banking collapse usually followed a credit boom financed by international capital inflows and an associated asset price boom in equities, railway bonds, and house prices (see Bordo, Eichengreen, and Irwin 1999; Marichal 1989). Government subsidies for risk taking in land speculation helped promote such an asset boom (see Calomiris 1999). The features of the boom were no different under the pre-1914 gold standard than in the post-World War II decades. The causes of banking collapses were a lack of market discipline in banking and a lack of fiscal discipline in the public sector. Recovery took a long time.

The aftermath of the interwar years, when the experience of banking panics led many countries to establish deposit insurance programs and hedge their financial systems with restrictive regulations, was an extended period free of banking crisis. This period ended when episodes of inflation in the 1970s undermined the stability of bank operations.

The introduction of deposit insurance in most countries during the second half of the $20^{\text {th }}$ century changed the relationship of central banks with the banking community. An agency other than the central bank was involved when troubled banks needed assistance in augmenting an inadequate capital base. Fiscal authorities became the source of capital funds for banks, which central banks were not supposed to provide. In the US, the legislation that provided for the reopening of banks after the Banking Holiday of 1933 authorized the Reconstruction Finance Corporation (RFC) to invest in the preferred stock or capital notes of commercial banks. The RFC was the forerunner of later use of fiscal agencies to rebuild a weakened banking system.

\footnotetext{
${ }^{2}$ The Bank provided liquidity to the market, and not to individual merchants.
} 
Problems affecting financial institutions other than banks and also conglomerates comprising financial and nonfinancial subsidiaries have emerged in both advanced and emerging market countries. As before, stock market crashes, though infrequent, have been a threat to financial stability. Widespread insolvency of bank and nonbank financial institutions as well as of conglomerates has generated a perceived need for rescue justified by the unchanged objective of protecting the functioning of the payments system. The rescue of Long Term Capital Management, a nonbank insolvent institution, is a recent example.

A separate issue arose for a central bank in an advanced country in the last century when a large financial institution became insolvent. The lifeboat rescue of Barings Brothers in 1890 by a committee of other banks and the Bank of England prefigured the $20^{\text {th }}$ century doctrine of too big to fail.

Whereas in earlier times the central bank was enjoined to lend only to temporarily illiquid but solvent banks, it has since been argued that the lender of last resort during a crisis cannot distinguish between an illiquid and an insolvent bank and, in fact, that it may be desirable to rescue an insolvent bank because of contagion effects on sound banks. Hence the practice of central banks has changed so that banks deemed "too big to fail" are resuscitated, and only small insolvent banks are closed (Goodhart 1987). Another modification of the rule to lend at penalty rates on good collateral is central bank assistance at market or below market rates with no collateral. One other modification is that central banks now prefer to be ambiguous about their commitment to provide financial markets with assistance in crisis conditions. "Constructive ambiguity" supposedly constrains excessive risk taking by financial institutions (Giannini 1999). These are the conditions under which domestic bailouts flourish.

The doctrine of too big to fail teaches that a central bank should rescue only banks above a threshold size. However, to avoid making known to commercial banks what the threshold size 
is, because such knowledge would influence their preferences for risk, it became a central bank belief that it should use constructive ambiguity about which banks it was likely to rescue (Goodhart and Delargy 1999). This was a pronounced departure from the classic prescription that size did not matter. What mattered was that only illiquid but solvent banks should be saved. And the market needed assurance that the central bank was committed to provide liquidity, not uncertainty about the commitment.

The rationale for saving big institutions, even if insolvent, was the fear of contagion. Continental Illinois was bailed out in 1984 on this ground. ${ }^{3}$ Moral hazard was unavoidable, given that the market knew the central bank would rescue banks in distress. One consequence of "too big to fail," was that the sheer size of a bailout required use of taxpayer funds. The central bank was no longer the chief mover and shaker. Special agencies had to be created to take over nonperforming loans of troubled banks, to recapitalize undercapitalized banks, to offer subsidies to bidders for a troubled bank, to pay off depositors. The large sums that were involved invited corruption. Regulatory and supervisory personnel were implicated in devising accounting gimmicks and exercising forbearance (Kane 1998).

Brief banking panics that a central bank could end by injecting liquidity through open market operations or by charging a penalty rate for a loan backed by good collateral have become prolonged banking disasters that fiscal authorities try to deal with at huge cost to the national budget.

\subsection{Evolution of debt crises}

Emerging market countries have been recipients of capital from advanced countries over the

\footnotetext{
${ }^{3}$ Recent evidence, however, suggests that contagion was limited in US banking panics in the past (Kaufman 1994; Calomiris and Mason 1997). Depositors were generally able to distinguish sound from unsound banks.
} 
centuries. The private sector has made funds available either as portfolio investments (British investments in Latin-American mining ventures in 1822-25), as bank purchasers of bond loans to governments (Barings loans to Argentina in the 1880s), or as bond loans to finance canal and railway construction (British investments in the US in the 1830s and 1870s).

Pre-1914, a sovereign nation or a private sector corporation that could not service foreign debts renegotiated the terms of the loans in private workouts with the creditors (Lindert and Morton 1989).

Defaults on borrowing by bonds led to the establishment of bondholders' committees in the creditor countries that would arrange a workout with the borrowers (Eichengreen and Lindert 1989). A restructuring of the debt would reduce the principal, lengthen the maturity, and possibly increase the rate of interest over the original rate. The arrangement was bilateral between the private parties, although sometimes before World War I the government of the lenders did not remain on the sidelines. Intervention was more characteristic of French and German than of US or British policy outside the British Empire itself. However, British nationals found in 1846, for example, in negotiations with Mexico, that government pressure was not invariably exerted on behalf of the bondholders.

In Argentina, following the Barings crisis, in 1893, an international committee of bankers headed by Lord Rothschild sought to induce policy changes with a liberal funding loan. The aim was to bolster the marketability of Argentine securities on the London market. In negotiations with the Argentine government, the Arreglo Romero was concluded. For five years interest payments were reduced by an average of $30 \%$ and amortization suspended for eight years. The British government did not intervene (Ford 1962).

Initially, bondholder committees were established ad hoc but were not invariably successful in winning investors' confidence or debtors' recognition. In 1868 loan houses and 
brokers in London created the corporation of Foreign Bondholders with a Council that constituted committees to deal with particular debtors. Because the Corporation was accused of promoting settlements favorable to the issuing houses, not individual bondholders, it was reorganized in 1897 to include representatives of investors. It won a royal charter in 1898.

Debtors who refused to accept the terms which the corporation offered were denied access to the capital market. Bondholder committees in other countries, however, did not necessarily agree with the terms that the British committees' favored, so debt settlements were not easily achieved (Eichengreen and Portes 2000).

Until the 1930s, this was the procedure for private negotiation of defaults on private international debts. A change occurred with the US emergence as a creditor country in World War I. US investment banks made foreign loans during the 1920s that defaulted by 1931, and government loans to Germany and other European countries defaulted by $1933 .{ }^{4}$ About 40

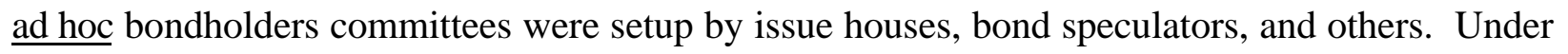
prodding by the State Department, the private sector established the Foreign Bondholders Protective Council, which operated independently of the government. There were disagreements about settlement between the British and US Councils (Eichengreen and Portes 2000). The private problems then became embroiled with US government problems in collecting its loans to foreign countries. The Johnson Act of 1934 made it a federal felony for a US bank to lend to a foreign country that had defaulted on its official debts to the US government. In addition, lending was deterred because of widespread capital and exchange controls in virtually every country except US and Canada. As a result, until near the end of Bretton Woods, US banks made no

\footnotetext{
${ }^{4}$ At issue is whether U.S. lenders took unusual risks or were caught by the disastrous collapse from 1929 to 1933 (see Friedman and Schwartz 1963, pp. 245-47; Bordo, Edelstein, and Rockoff 1999).
} 
foreign loans, and US securities firms underwrote no foreign bonds. Accordingly, until that point in time, because the markets were moribund, there was no reason for a foreign bailout policy.

For Walker Todd (1999), 1969 was the date marking the resumption of US private bank foreign lending abroad. A syndicated bank loan to the government of Iran for the purchase of military airplanes was then negotiated. It inaugurated a series of such syndicated dollar loans to Latin American countries during the next dozen years that were excessive as a ratio to the capitalization of the lead New York money center banks (Schwartz 1989). East Asian countries were also recipients of international loans. The syndicates included US, European, and Japanese multinational banks. Regulatory officials in the years after the 1973 oil crisis encouraged lending of petrodollar deposits at these banks to emerging market countries.

This spurt of international lending ground to a spectacular halt in August 1982, when Mexico announced that it could not service its debt. Other Latin American countries followed Mexico's example. The Federal Reserve and the IMF took on the mission of mediating debt negotiations between the borrowers and financial community (Boughton 1999; James 1996). The strategy of officials at the Federal Reserve, the Treasury, and the international multilateral financial agencies was to obfuscate the dire situation of the US money center banks. The officials exhorted them to lend new money so the delinquent debtors would be able to pay the interest due, to maintain the fiction that the loans were sound. For the debtor countries the crisis spelled the reversal of capital inflows, the service of debt exceeding new credit flows. Growth and development of the debtor countries became severely constricted during the balance of the 1980s. One suggestion for coping with the crisis was to mark down debt to the market price, and exchange it for minority equity stakes in debtor country enterprises (Meltzer 1983).

By 1987 the banks, less vulnerable than they were five years earlier, stopped playing the game that the loans were sound and began to provision them on their books, so they could charge 
off principal writedowns. Some banks sold emerging country debt in the secondary market that began to function in 1984. The principal of the debts at that point had increased by the amount of the new money. A 1985 plan by Treasury Secretary James Baker for the lending banks to increase their loans to the debtors beyond the amount that payment of interest due required, foundered on a growing divergence of interests between European and Japanese banks that lacked tax and reserve advantages and American banks that would have enjoyed them if they participated in the plan.

Official action to end the debt crisis was finally undertaken in 1989, when US Treasury Secretary Nicholas Brady proposed a solution. Each debtor negotiated about a 35\% debt reduction on part of its loan with its bank creditors. The remainder of the debt was collateralized by the debtor's purchase of special nonmarketable zero-coupon US Treasury securities, with 20to 30-year maturities. Brady bonds are held at the Federal Reserve Bank of New York for some debtor countries and at the BIS for others for the eventual redemption of the principal of emerging market country bonds that were issued to the banks as part of the Brady plan debt exchanges.

The Brady plan has been described as concerted market-based debt relief (Bowe and Dean 1997). Its success has been evaluated relative to its effects on the debtor countries, the banks, and taxpayers. In 1994, the debtors appeared to be better off because secondary-market prices for developing country debt rose, access to international capital markets was restored, and growth in GDP and exports resumed. For a 33\% debt reduction followed by a 50\% increase in the value of the remaining debt, the banks that signed the Brady agreement were $17 \%$ better off. The minority of banks that did not sign was $50 \%$ better off. The collateral for Brady bonds was provided mainly by the official lenders, little by the debtor country, so failure to repay by the debtors may cause losses for taxpayers. 
Mexico signed the first Brady agreement in 1990. Twenty-one other countries followed between 1992 and 1996 (see Bowe and Dean, 1997, p. 13). Capital markets then revived, and new bond issues, but not bank lending, began. Latin American and East Asian countries were the ones that raised capital on the bond market (Bordo, Eichengreen, and Irwin 1998).

Despite the belief that the Brady plan had a successful outcome, and that Mexico was a prime example of the plan's success, the country was in crisis again at the end of 1994. A more recent example of post-Brady problems is that of Ecuador. In August 1999, it missed two Brady bond coupon payments. It chose not to make the $\$ 44.5$ million payment at the end of a 30 -day grace period. Once the bonds valued at $\$ 6$ billion are formally in default, a $25 \%$ voting bloc of bondholders can demand immediate payment of the principal. That has not happened.

Negotiations to restructure the terms of the loan are scheduled to begin in Washington during the last week of April 2000. The market suspects that the IMF did not pressure Ecuador to pay on time in order to inflict a loss on the bondholders. The reason for so doing is that the IMF is eager to deflect the criticism that its lending creates moral hazard (O'Grady, Wall Street Journal, Sept. 17, 1999).

It has been argued that foreign lending inevitably ends in a bust because of asymmetric information. The borrowers have more information about the viability of projects in the host country, and the lenders are fooled. When they become aware of the poor results of their investment, they withdraw their capital, precipitating a debt crisis. If the host country has pegged its exchange rate, the withdrawal of foreign capital imposes reserve losses on the monetary authorities and causes foreign exchange rates to collapse. A debt crisis metastasizes into a currency crisis. Thus has the transit occurred from the debt crisis of the 1980s to those of the 1990s. 
A major difference between the debt crisis of the 1990s, in Mexico, the East Asian countries, Russia, and Brazil and those of the 1980s is in the scope of the intervention by the multilateral lending agencies. In the 1980s, the debt was owed by governments. In the 1990s, in Asia, the debt was owed by banks and companies. The losses remain to be allocated among borrowers, lenders, company owners, and governments. Absent bankruptcy laws, it is difficult to shut down insolvent firms, and settle with creditors.

A justification for intervention by international financial institutions or the US government has been offered in the wake of the 1990s crises. These crises occurred, on this interpretation, because of coordination failure among investors, for any one of whom it was optimal to withhold liquidity from the affected countries, although all investors would have been better off if everyone of them had provided the needed liquidity. It is the ability of the US government and the international financial institutions to replace the liquidity investors withdrew that circumvents the problem of coordination failure and justifies official intervention (Marshall 1999; Eichengreen 1999).

In the Mexican bailout in 1995, holders of tesobonos suffered no loss. In Korea in December 1997, Japanese, European, and US banks agreed to roll over loans to avoid default by the borrowers. Restructuring of these loans has since been arranged. The IMF has been "lending into arrears," since the 1980 s, giving loans to countries in arrears, initially only after they had reached an agreement in principle with their foreign commercial bank creditors. By the end of the decade, however, the banks resisted sharing the burden with the debtors, and the IMF began to support an adjustment program before a member had cleared away its arrears to a commercial bank. It does so in the expectation that lending into arrears will drive creditors to the negotiating table and that a settlement with a debtor will follow. Lending into arrears has been criticized as creating moral hazard, and that instead adjustment efforts by debtors should be emphasized. 
Proposals for the establishment of bondholders committees that would be recognized by creditor-country governments have been made to speed negotiations between private creditors and sovereign debtors (Eichengreen and Portes 1989). A majority of creditors would have the right to alter the terms of loan contracts and bond covenants (Buiter and Sibert 1999). This would require legislation in the US to change legal provisions governing bonds issued here that unanimous consent of the bondholders is needed to restructure a bond. In the UK, by contrast, a majority vote at a bondholders meeting binds all bondholders (Eichengreen 1999). The proposal to incorporate new clauses in loan contracts is a measure of the distance that has been traveled since the 1930s when bondholder committees were organized by the private creditors without government or international prodding.

Since the 1980s, the public sector has intervened in debt crises, either delaying the workout or, after a lapse of years, organizing the workout that sharply discounted the outstanding principal (Lindert and Morton 1989). There is a contrast between the length of time that the resolution of earlier crises required and the resolution of crises since the 1980s - 3 years in the case of the Barings crisis, 7 years in the case of the 1980s debt crisis. One should note, however, that it took close to a decade before serious lending to Argentina resumed after the Barings crisis. The 1930s defaults also involved a protracted period until the 1950s to resolve them. Long and tangled negotiations were conducted between bondholders committees and the government borrowers. The latter contributed to the resolution by secretly buying their debt in the bond market at deep discounts during default (Jorgensen and Sachs 1989). The resolution was prolonged, it has been suggested, because the debtors fared better the longer they held out. Another change from earlier practice is that governments have offered guarantees to induce foreign lenders to provide funds to the private and official sectors. 


\subsection{Evolution of currency crises}

A currency crisis is a market-based attack on the exchange value of a currency. It differs from a banking panic, which sharply increases the demand for currency, but the two types of crisis may feed upon one another.

The traditional view of currency crises is that pegged exchange rates are durable only as long as monetary authorities are credibly committed to maintaining them. Domestic economic policy must always be subordinated to the objective of maintaining the fixed exchange rate. In the traditional view, speculative attacks on a currency are driven by the incompatibility of the pegged exchange rate and expansionary domestic financial policy (Bordo and Schwartz 1996a). A more recent view is that currency crises are not necessarily driven by a conflict between deteriorating fundamentals and the pegged exchange rate, but can reflect self-fulfilling prophecies (Obstfeld 1994). An innovation of the traditional view is that the timing of the attack is predictable (Krugman 1996; Flood and Garber 1984). It occurs before the monetary authority has exhausted its reserves. On the more recent view, the timing is not predictable. Because market participants expect that the monetary authority's policies will be inconsistent with the peg, they will take actions to force the authority to abandon the peg and thereby ratify their expectations. What matters to speculators is the tradeoff monetary authorities have between domestic and external goals and how they will react when faced with a crisis. Crisis can occur in circumstances of multiple equilibria - indeterminacy - in foreign exchange markets, in which random shocks called sunspots can trigger an attack.

An examination of currency crises over two centuries reveals that they occurred when internal economic conditions were incompatible with the external conditions set for the currency. Institutions and circumstances in which currency crises occurred differed widely among countries, but common to all these experiences was the basic incompatibility. 
Before World War II, when a commodity standard prevailed, the commitment to convertibility by advanced countries was strong. If currency crises occurred there, they were a result of a government's questionable financial practices or of banking instability. Crises in advanced countries usually occurred on the outbreak of war, when market participants understood that governments would suspend convertibility in order to pursue the war effort (Bordo and Kydland 1996). In peacetime, currency crises were usually associated with banking instability, generally short-lived, following which the original parity was restored.

Emerging market countries, however, suspended convertibility under speculative attack by market participants' recognition that governments were pursuing lax financial policies (Bordo and Schwartz 1996b).

Currency crises were features of the Bretton Woods years when countries, whose parities were subject to speculative attacks because their internal and external policies clashed, either devalued or obtained loans that rescued them. The demise of Bretton Woods ushered in the movement towards a worldwide international capital market. This is the background to the recent spate of currency crises.

The Bretton Woods system was exposed to currency crises under two sets of circumstances. Some countries adopted fiscal and monetary policies that were incompatible with a commitment to the peg. Other countries faced currency crises if competitive trends had changed the real exchange rate, requiring adjustment of the nominal parity. Countries, however, resisted altering their parities because of adverse capital movements if there were only a hint of devaluation or of revaluation. When delayed adjustment finally was compelled, it was traumatic. Capital controls could support the delay but in the end could not avert an attack on the peg that either set of circumstances precipitated (Bordo 1993). 
Threats to the domestic currency have arisen not only when real shocks, such as terms of trade shocks, have affected its exchange value, but also when loose monetary and fiscal policies designed to counter real shocks instead have destroyed confidence in the currency. The type of monetary regime is clearly significant for a financial crisis involving the domestic currency. When a regime is based on a credible convertibility principle, where maintenance of a currency's parity is an important commitment, stabilizing capital flows will offset incipient crisis and, if that is not sufficient, rescues will finance a country's willingness to sacrifice domestic national income in order to honor its commitment. In monetary regimes without such commitments, a higher priority will be assigned to the attempt to preserve domestic national income rather than external foreign exchange goals. Capital flows may not be stabilizing in this case, nor rescues successful.

International capital mobility has played a critical role in currency crises. Central banks in emerging market countries can serve as lenders of last resort for domestic borrowers with domestic-currency denominated liabilities. In these countries, however, ordinary banks may borrow foreign currency and make domestic loans not only in domestic but also in foreign currency. If there is a surge in demand for foreign currencies, central banks can provide only the available foreign exchange reserves they hold; they cannot create more. Additions to their foreign exchange can only come from an outside source. The foreign exchange value of a currency can plunge when capital inflows are reversed.

In today's world of highly mobile capital and deep international capital markets, advanced countries can borrow whatever international reserves are required to defend their parities, but the price of doing so is astronomical short-term interest rates e.g., Sweden in 1992, UK 1992. The market is aware that those rates are soon prohibitive and the attack on the currency succeeds (Obstfeld 1994). 
Recent currency crises have resulted from speculative attacks on pegged exchange rates that the market deemed vulnerable. In every currency crisis, the fundamentals can account for the actions of speculators. It does not greatly improve our understanding of these crises to attribute them to self-fulfilling prophecies.

\subsection{Evolution of combinations of crises}

Concurrent banking, currency, and debt crises appear to be a condition to which emerging market countries in particular were and are subject. As recipients of capital inflows, they became debtors, and if the inflows were invested in unprofitable ventures, the solvency of banks was imperiled. When banks and local firms borrowed in foreign currency and sold their products for local currency, their balance sheets were vulnerable if the exchange value of the local currency came under attack. These were and are the dimensions of financial instability in these countries before World War I and during the current float (Bordo, Eichengreen, Irwin 1999; Bordo and Eichengreen 1999; Goodhart and Delargy 1999).

There seems to be less of an evolutionary and more of a repetitive nature in the combinations of financial crises in emerging market countries. The fact that repeated attempts to stabilize financial markets in these countries have not been crowned with success suggests that there are elements in their economies that make financial stability elusive. The usual explanations for the improved financial performance of advanced countries in recent decades, if one overlooks banking problems in the late 1980s and early 1990s, is that, at the national level, they have stabilizing institutions like central banks and financial safety nets, and at the international level, they can rely on the IMF, the WTO, and the Basle Committee of Banking Supervisors. But these institutions also exist at the national and international levels for emerging market countries. The financial safety net has created moral hazard and has not prevented financial catastrophe. Financial instability, however, is a facet of underdevelopment. The need to 
improve the financial structure is another facet of underdevelopment. It was the case of the US in the $19^{\text {th }}$ century. The question is whether a lender of last resort is sufficient, whether a safety net is overkill.

An explanation of financial instability that applies to emerging market countries fastens on the disruptive effects of capital inflows, in particular, short-term inflows. The solution on this view is a tax that would penalize such inflows (Eichengreen 1999; Tobin 1978). ${ }^{5}$ Yet the problem has not been the inflows per se, but their malinvestment. A better corrective would be to limit the liquidity effects of the inflows, a task the emerging market central bank could accomplish (Schwartz 1998).

Stabilizing the emerging market economies, however, requires more basic changes. The IMF has tried to impose political economy conditions on these countries as part of its lending programs. It has not been notably successful. The World Bank has also been a lender to emerging market countries on whose economic policies it has had only limited impact. It is clear that the countries themselves need to find the political will to change, and that, despite fifty years of the ministrations of the international financial institutions, the countries have not achieved the status of development. Some of the financial technology can be imported but not the will. The evolution of each type of financial crisis considered above might suggest that turning the clock back was a good idea. In the case of combinations of types of crises in emerging market countries, on the other hand, turning the clock forward seems to be indicated.

\footnotetext{
${ }^{5}$ Chile restricted capital inflows beginning 1991. It imposed minimum stay requirements for direct foreign investment, and non-remunerated reserve requirements on other capital inflows. Capital importers had to deposit a non-earning $20 \%$ of an inflow at the central bank for one year. The deposit was increased to 30\% in May 1992, reduced to $10 \%$ in July 1998, and totally eliminated in Sept. 1998. The restrictions altered the composition of capital inflows, discouraging inflows of less than a year, but the total volume of inflows continued to increase except for a brief decline in 1993 (Edwards 1998, 1999).
} 


\section{Evolution of international lending in financial crises}

As noted above, to deal with banking panics central banks learned before World War I to extend loans of high-powered money to all solvent banks and solvent borrowers that were temporarily illiquid. The only institution that had the resources to provide such loans was the central bank, which could create high-powered money without limit, and hence was the lender of last resort. The objective was to prevent an impairment of the payments system. This could happen when fears prevailed that funds were not available at any price to enable sound debtors to make payments that were due. A stock market crash could also generate such fears and thus endanger the payments system, although the crash in and of itself simply reduced nominal wealth. The classic prescription for the exercise of lender of last resort responsibility was limitation of loans to solvent borrowers only that would pay a penalty rate for the loan and offer good collateral, itself an indication that the institution was indeed solvent.

To deal with currency crises before World War I, monetary and fiscal authorities, faced with a shortage of international reserves, possibly because of a deficit in the balance of payments, needed a temporary source of gold or foreign exchange. One source was a foreign central bank that would come to the rescue of the country with a deficit. ${ }^{6}$ Another source was a private investment bank that organized a syndicate of banks in several countries to lend gold on commercial terms to stem a loss of reserves by the government in distress, e.g., Rothschild, Morgan. The loan was repaid as equilibrium was restored to the balance of payments.

International capital flows under the gold standard, however, affected the position of both lending and borrowing countries. A lender that shut off capital outflows because its

\footnotetext{
${ }^{6}$ Thus in the period from 1825 to 1913 , on many occasions the Banque de France extended temporary credits to the Bank of England and vice versa (Bordo and Schwartz 1999).
} 
international reserves were falling in turn caused difficulties in the borrowing countries. The loss of capital inflows made it impossible for the borrower to service foreign debts, banks failed, and the exchange value of the domestic currency depreciated. Inability to service foreign debts created a debt crisis. The parties to the debt contract, as in the events of 1893 and 1907, negotiated a reduction in principal, the term of the debt, and the interest rate to be paid.

Changes in monetary regimes after 1914 are associated with an altered role of international lending. With respect to currency crises, the nature of the rescue has varied according to its timing and to the amount of international reserves offered. The timing determines whether the rescue is designed to prevent a currency depreciation or to provide reserves following a depreciation. The amount of reserves the loan offers determines whether or not a bailout of domestic and foreign creditors is intended.

The US Treasury Exchange Stabilization Fund has played an important role in promoting lending to countries in financial distress and in introducing the notion that there should be multiple lenders to a given borrower, mainly the new multilateral international agencies that were created after World War II. The IMF itself is an offshoot of the ESF (Gold 1988). ESF stabilization loans date from 1936, initially to Latin American countries. Under Bretton Woods the ESF loans were combined with IMF standby arrangements, Export-Import Bank foreign currency credits, and assistance from the International Cooperation Administration and the Agency for International Development that was established in 1961. The BIS, individual central banks, the World Bank and its offshoots in recent years have also contributed to loan packages. At all times, the ESF contribution to these packages was small.

The rescue of individual troubled institutions in recent years then has at times involved domestic central banks, sometimes supported by private institutions, and in the case of Long Term Capital Management, wholly resolved by private institutions although supervised by the 
Federal Reserve Bank of New York. The most significant development has been the takeover of the liabilities of insolvent banks by government agencies that offer mispriced deposit insurance, and the use of fiscal sources of funds, such as the Resolution Trust Fund, for bailouts of undercapitalized financial institutions.

\subsection{Historical perspective on international lending}

The chronology of events we cover here applies to lending that, on the one hand, produced debt crises and, on the other, served to resolve banking and currency crises.

\subsubsection{1-1914}

In the $19^{\text {th }}$ century, short-term international loans were made by foreign commercial and merchant banks to finance current international trade (Bordo, Eichengreen, and Irwin 1999). Medium- to long-term loans provided bond-financing for emerging market country projects. There were three waves of British capital exports to Latin America: 1822-25 to finance gold and silver mines, ending in a stock market crash in London and a banking panic; 1854-73 to finance railroads, ending in a European financial crisis and debt defaults by the borrowers; 1884-90 to finance interior development of Argentina and Uruguay, ending with the crash of Barings, a default of Argentine state bonds, and the declaration of a moratorium (Marichal 1989)

The US was also the recipient of British capital exports: 1826-37, to finance canals and cotton fields, ending in a depression that lasted until 1843, when eight states defaulted on their debt; 1863-73, to finance westward expansion, ending in the panic of 1873 . There was a capital outflow in 1895, when agitation for silver threatened US commitment to gold convertibility.

British capital exports to Australia in the 1880s financed a land boom, ending in a bust in 1890, and in1893 in massive bank insolvencies because of loans on land collateral. Canada's internal development was also financed by British capital (Davis and Gallman 1999). 
Banking panics in Britain in 1825, 1837, 1847, 1857, when the Bank of England raised its discount rate because of a decline in its gold reserves, had adverse effects on capital exports. British merchant banks that had been financing cotton exports from New Orleans to Liverpool, in 1837 were forced to cut back their operations. As a result of a fall in the price of cotton, debts secured by cotton in the US became uncollectible. Merchants, brokers, and factors failed. Banks suspended specie convertibility and many failed nationwide (Levy- Leboyer 1982).

Ripple effects of the Barings crisis of 1890, the banking crisis of 1893 in the US, Italy, and Australia, and the 1907 crisis in the US and Europe were transmitted to other areas through the exchange rate links of the gold standard, but capital exports resumed once financial stability was restored.

\subsubsection{World War I and the Interwar}

During World War I US banks financed British and French wartime purchases in this country. The US Treasury then used the proceeds of Liberty Loans to pay the British and French sovereign debts, in effect paying off the US banks.

After the war, the US refused to participate in efforts by the Allies to impose reparations on Germany and Austria. To deal with the burden that reparations placed on Germany, first the Dawes Plan of 1924 and then the Young Plan of 1929 rescheduled reparations, reducing them to a fifth of the original principal amount, and gave Germany loans to ease the reparations burden.

A 1923 US-UK settlement provided refinancing of the British war debt over a 62-year period at a 3-3.5\% interest rate. A similar settlement with France brought down the present discounted value of its debt to $\$ 2.2$ billion (Moulton and Pasvolsky 1932)

As part of the program to restore the gold exchange standard after World War I, loans were made to Germany and Austria in 1922-23 under the auspices of the League of Nations, and after 1924 by the Federal Reserve and the Bank of England and other central banks as part of a 
stabilization package including provisions for a balanced budget, monetary stability, and an independent central bank. J. P. Morgan extended \$100 million to France in 1924 to help stabilize the franc after its precipitous decline since 1922. In 1925 US credits helped Britain return to convertibility.

The interwar years witnessed the banking panics of the Great Depression. Interbank loans to rescue Austria in May 1931, Hungary in June 1931, Germany in July 1931, and Britain in September 1931 proved inadequate to halt the serious banking troubles in each country. With their currencies under attack, the central European countries opted for exchange controls. Britain suspended convertibility.

Although the US was not forced off the gold standard, the dollar was allowed to float in April 1933 and was repegged to gold in January 1934 at a greatly devalued parity. The currencies of the countries that had remained on the gold standard faced pressures from the competition of depreciated sterling, capital flows to the US, and exchange controls elsewhere. Despite a rescue attempt, Belgium left the gold bloc in March 1935, as did France in April 1936, with no rescue loan but the Tripartite Agreement it negotiated with Britain and the US (Bordo and Schwartz 1999).

During the 1920s US banks floated foreign securities on a large scale, many of which defaulted by 1930-31. In July 1931, following the banking crisis in Central Europe, the US engineered a standstill agreement on German trade bills and bank acceptances in the portfolios of U.S. banks. The Debt Default Act of 1934, which made bank lending to a foreign country in default on its official debt to the U.S. a federal felony, effectively ended new foreign loans for decades.

The only foreign loans that were made after 1934 were ESF loans to Mexico in 1936 and 1938, to China in 1936, and to Brazil in 1938. The ESF treats all currencies as equal. A US 
dollar loan is the same as a Mexican peso loan, but a currency loan must be repaid in the currency that was borrowed. The interest rate applied to the loan is not revealed in the documentation of the loan, but archival material suggests that it was below the commercial rate. ESF lending has continued on this basis since 1936, with a huge increase in the amount made available to Mexico in 1995.

\subsubsection{1-1973}

The US extended Lend-Lease loans to the Allies during World War II. The debt was largely forgiven after the war, when it was written down to 4 cents on the dollar. In 1946 the US gave Britain a loan of $\$ 3.75$ billion (Canada added $\$ 1.25$ billion). The terms were five years' grace on principal and 50 years to pay, interest fixed at $2 \%$ and an interest capitalization clause for any year in which the UK could not repay.

The other main postwar US government loan was the Marshall Plan for Western Europe in 1947-53. The total amount was about $\$ 13$ billion, repayable in depreciated local currencies.

The Bretton Woods era was marked by currency crises that affected countries with parities inconsistent with domestic policies and competitive trends. The crises were resolved either by devaluations, revaluations, or by IMF or G-10 rescue loans. In two instances (sterling, November 1967, and the dollar, August 1971) currencies that were under attack succumbed, despite rescue loans for the former and varied devices to protect US gold reserves. In several other instances (the Canadian dollar, June 1962, the lira, March 1964), the rescue loans were successful. As the resources required for rescues mounted, the Bretton Woods system fell apart, a dissolution that the policies of the US, the center country, compelled (Bordo and Schwartz 1999). 


\subsubsection{1-1990}

The resumption of US bank lending abroad in 1969 and the upsurge in these loans in the 1980s has been noted in the subsection on the evolution of debt crises. Structural and humanitarian loans to low-income countries to enable them to buy high-priced oil were not rescue loans. Neither were the recycled loans by syndicated commercial banks in advanced countries, in which OPEC deposited the huge increase in its revenues. The loans mainly to the public but also to the private sector in Latin American countries imposed debt service plus amortization that virtually exhausted current account income. As foreign debt increased, the ratio of debt to GDP soared. Capital flight became pronounced. Debt service by both the public and private sectors came to a halt in 1982. The outcome, described above, was not an international rescue. The initial concern was the condition of the US money center banks.

The debt crisis of the 1980s is not a precursor to the bailout loans of the 1990s. In the 1980s US money center banks were saved from closures by the actions of the IMF and the US monetary authorities but they were not bailed out in the sense that they were not saved from major losses on their loans to the emerging market countries.

Rescue loans before the 1990s were made in an attempt to prevent a devaluation or the abandonment of a pegged exchange rate by the core advanced countries. They were temporary loans, at commercial market interest rates, limited in magnitude, but sufficient to offset a current account deficit. No taxpayer money was involved. The loans accompanied a package of remedial policies. The two-year stand-by loan to Britain in December 1976, for example, included a package of economy measures intended to stem a flight from sterling.

ESF stabilization loans before the 1990s were extended mainly to emerging market countries. They were temporary bridge loans or available usually for one or two years, limited in 
magnitude, and after World War II combined with loans from multilateral lenders. The interest rate charged was believed to be below market.

\subsubsection{Loans Since the 1990s}

Rescue loans in the 1990s have been extended to emerging market countries and to Russia, a country in transition from a command economy. The loans have been multiples of the amounts that were granted in the past. The recent loans are intended to offset a capital account outflow, the effect of which was to endanger repayment of the lenders. The size of the loan was enough to provide the wherewithal to repay foreign and domestic lenders of foreign currency, involving a wealth transfer from taxpayers to wealthy investors. In this sense they represent bailouts and not simply rescue loans.

The chief indictment of the bailout model of international lending is that it promotes moral hazard. In the crisis countries, investors believed that there was an implicit government guarantee against failure of banks. If banks were threatened because depositors wanted foreign exchange for domestic deposits, governments would provide it until its foreign exchange reserves were exhausted. When foreign bank deposits were no longer guaranteed, investors decamped (Dooley 1997). International loans then replaced government guarantees. Lenders presumed that, whether or not the resources they provided were put to productive use, they were not at risk. Borrowers presumed that, if there were a reversal of the conditions that invited the inflow of funds, their debts would be repaid by others or drastically discounted.

Bailouts on the international level are complemented by bailouts on the national level. Governments refrain from closing banks with inadequate capital and portfolios of nonperforming loans. The banks are deemed too big to fail. When the government budget permits, resources will be allocated to provide additional capital and to clean up the asset side of the banks' balance sheet, or perhaps a foreign bank can be induced to buy a share of such a bank. Bankrupt firms 
continue to operate, and creditors are unable to foreclose them. Emerging market economies that have succumbed to the bailout syndrome are adrift (Kane 1998).

Accounts of the emerging markets that were granted bailouts in the 1990s follow.

Mexico's financial crisis, which had been building up in 1994 with problems affecting the exchange rate of the peso, the current account deficit, the inflation rate, government borrowing in dollar-indexed amounts, monetary base growth, declining international reserves, and a banking system with a rising ratio of nonperforming loans, nevertheless came as a bombshell at year-end, when the peso was freed to float and foreign capital fled. The peso exchange rate rose from about 3.5 to 5.0 per dollar (subsequently to about 10 per dollar) (Edwards 1997; OECD 1995).

At the end of January 1995, President Clinton announced a package of loans for Mexico including \$20 billion from the ESF, available for loan guarantees for up to ten years. Theretofore, the upper limit for ESF credit for any country was \$1 billion and 6 months. In addition, the ESF and the Federal Reserve offered up to \$6 billion in emergency swap line credits. The IMF extended about $\$ 18$ billion, and together with other lenders, the package Mexico obtained totaled $\$ 41$ billion. The amounts it actually borrowed totaled $\$ 32.5$ billion during 1995 and early 1996: \$12.5 billion from the US, \$14 billion from the IMF, and \$6 billion from other official sources.

Mexico repaid the US loans in August 1996 and January 1997. It repaid the loans with the proceeds of loans from European and Japanese lenders. As early as July 1995, Mexico was able to sell German banks 5-year Eurobonds. On October 5, 1995, it sold another 1 billion DM denominated 5-year Eurobonds, roughly equivalent to \$700 million, paying 9 3/8 percent interest, similar to the earlier issue. The interest rate on both borrowings was about 400 basis 
points higher than German bonds of comparable maturity paid. ${ }^{7}$ Mexico still owes the IMF about $\$ 6.1$ billion, but has arranged a new credit line of $\$ 23.5$ billion with the IMF and the World Bank as ammunition in the event of an attack on the exchange value of the peso during the election year of 2000 .

The Mexican bailout has been hailed as a great success (see Figure 1 for evidence on the recovery in growth after the crisis). It turns out, however, that in the four years after the bailout, only the traded goods sector has revived. There has been no recovery in the nontraded goods sector, which accounts for at least $50 \%$ of GDP. The reason for the continued slump in the nontraded goods sector is that there has been a five-year credit crunch and enterprises cannot obtain bank credit. The banking problems of insolvent institutions and high ratios of nonperforming loans that existed in 1994 still exist in 1999 (Krueger and Tornell 1999). A report this year by an outside auditor of the banking system found continued undercapitalized banks, poor loan portfolios, inexperienced management, and a regulatory and supervisory environment not prepared to allow insolvent or heavily subsidized banks to fail. Some reform measures may, however, finally be under way, although the industry has been so scandal-ridden, one must remain skeptical. One reform measure that may come to pass is the phasing in of reductions of $100 \%$ government deposit insurance coverage over a period of years to rein in

\footnotetext{
${ }^{7}$ The Mexican Debt Disclosure Act of April 10, 1995 changed the process of setting the interest rate the ESF charged on medium-term swaps with Mexico. Prior to the legislation the ESF interest rate on these swaps was a sum of the latest auction rate on US Treasury Bills, reset at the end of each quarter at the latest T-Bill auction rate, plus a credit-risk premium Under the April 10 law, the rate is a fixed percentage set at the date of the loan and not reset at the end of each quarter. The credit risk premium the ESF charged on Mexico's drawing on March 14, 1995, that was reset on March 31 and subsequent end of quarter varied between 2.39 and 2.46 percent. The interest rate the ESF charged on April 19, May 19, and July 5 swaps ranged between 9.20 and 10.16 percent, and the implicit credit premium ranged between 3.67 and 4.46 percent. The credit premium the German banks charged Mexico was not out of line with the ESF numbers.
} 
undue risk-taking at taxpayers' expense. Another reform will allow greater foreign entry into the banking industry.

Optimism about improvements in Mexico's economic fundamentals is based on Moody's March 7, 2000, announcement that it had upgraded its rating for Mexico's government bonds to Baa3 investment-grade (Standard \& Poor has not yet done so); on the Bank of Mexico's achievement of its 1999 inflation target of 13 percent; on the narrowing of the trade and current account deficits; and on higher oil prices. Mexico's record in the past 50 years of retrogression following indications of economic progress suggests that caution is advisable about projecting its good prospects. Looking back on the official response to the peso crisis in 1994-95, the question that must be asked is why Mexico could not have tapped the capital markets directly in 1995, had there been no US Treasury intervention. It could offer oil revenues as collateral, and was willing to pay a market rate of interest reflecting credit risk, as was clear when it borrowed abroad in 1995 to repay the Treasury. Absent a bailout, would not reform measures have been more urgent?

$\underline{\text { Asian }}$ countries with financial crises in the 1990s shared the common element of weak banking systems. Banking crises arose because of an excessive expansion of credit, and a decrease in the creditworthiness of the projects the banks financed. Credit allocation was not market driven. Political influence was exerted on the banks to lend as directed. Loans were channeled to create unprofitable industrial capacity and the purchase of equities and real estate. Regulatory corruption shielded banks from penalties for not observing regulations.

Yet it was not the condition of the banks that triggered the financial crisis. In each country the exchange rate was pegged to the dollar or another hard currency. The trigger was a currency crisis. Stock market declines matched the currency devaluations (Schwartz 1998; Radelet and Sachs 1998; Corsetti, Pesenti, and Roubini 1998). 
It was not contagion following the fall of the Thailand bhat that led the currencies of the other countries to slip their pegs. In each case, excessive short-term foreign borrowing, a banking sector weighed down by speculative property loans, and corrupt government and business practices accounted for the currency's fate.

Of the five Asian crisis countries, only Malaysia refrained from requesting IMF assistance. The Philippines had been getting IMF assistance for decades, but in April 1998 obtained an additional $\$ 1.35$ billion (161\% of quota). Taiwan, not a crisis country, held huge foreign exchange reserves, and Hong Kong had a credible currency board.

In August 1997 a $\$ 20.1$ billion bailout package was assembled for Thailand. The IMF contributed a standby credit of $\$ 3.9$ billion (505\% of its quota). The World Bank contributed \$1.9 billion, the Asian Development Bank \$2.2 billion, and other Asian countries \$12.1 billion. In November 1997 the IMF agreed to give Indonesia a standby credit of $\$ 10.1$ billion (490\% of its quota). The total package came to $\$ 40.1$ billion including $\$ 22$ billion from other Asian countries and an additional $\$ 8$ billion from other official facilities. In July 1998 the IMF and other international lenders promised Indonesia an additional \$6 billion. In December 1997, for South Korea, the IMF approved a $\$ 21$ billion loan (1939\% of quota) over three years. The ESF contribution was $\$ 5$ billion, and the total package came to $\$ 57$ billion.

The question that needs to be asked about the Asian bailouts is: Who has benefited? The bailout protects investors who lent money to governments or private sector institutions. The bailout does not solve the fundamental need for a workout negotiated by debtors and creditors when there are difficulties in servicing a foreign debt. The argument that creditors are too numerous and dispersed for rescheduling to occur without disbursements from the official sector is contradicted by the workouts the Asian countries have arranged. In South Korea international bank creditors at the end of January 1998 restructured \$24 billion outstanding short-term loans to 
the South Korean banks. The South Korean government guarantees the new loans. In Indonesia, a plan to restructure $\$ 80$ billion short-term foreign debt owed by private corporations, banks, and importers involves guarantees by the Indonesian central bank of new restructured loans. If it is true that the workouts would not have occurred had there been no IMF loans, the funding needed to promote a workout was surely less than the amount offered (De Gregorio et al. 1999). Indeed, the fact that the IMF is the senior creditor, demanding repayment of its loan ahead of all other creditors, far from inducing others to want to supplement IMF lending, as the current incantation propounds, may actually be a deterrent.

Have the bailouts stabilized the Asian economies? Ul Haque and Khan's (1998) review of statistical studies that measure the impact of IMF funding programs on four indicators for borrowing countries (balance of payments, current account deficits, inflation, and growth) conclude that recent results find the programs more effective than earlier analyses (see section 7 below). The studies do not distinguish between countries that implemented reforms and those that did not. Have the bailouts hastened reforms? The weaknesses of the banking systems persist. They contributed to the severity of the recessions post-crisis. The balance sheets of nonfinancial firms as well as of financial institutions still need to be restored. Moreover, the bailouts have burdened the Asian countries with debt loads that are excessive in relation to their GDP. For example, Indonesia's government budget deficits since the currency crisis began have been financed by donor nations. The government's debt now amounts to $\$ 68.4$ billion, which the World Bank estimates will be $102 \%$ of GDP by the end of 1999 . The debt figure excludes an estimated $\$ 78$ billion that the government will incur for bank bailout costs, and an additional \$9 billion to cover the debts of state-owned companies. Is mounting debt the cure for what ails Indonesia? 
Indonesia missed a March 31, 2000, target date to implement 14 reform programs it had promised the IMF it would achieve, and the IMF responded by delaying disbursement of $\$ 400$ million in loans. Since then the government passed legislation that would enable it to restructure $\$ 2.1$ billion of government debt at a meeting with Paris Club sovereign donors. New measures were also passed to recast the agency setup to restructure $\$ 60$ billion debt owed by Indonesian borrowers other than the government.

East Asia will eventually recover, but it is a problem to identify in what respects the bailouts will help to achieve that result. Stock market recoveries in the crisis countries have not been accompanied by comparable expansion of real economic activity.

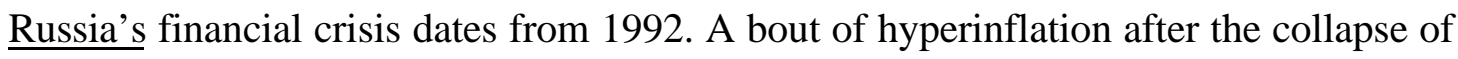
the soviet regime ended when the central bank gained control of the supply of rubles. In August 1992, April 1995, and March 1996 the IMF gave Russia a credit line total of about $\$ 9.1$ billion in exchange for promises of reform. Political disarray and financial turmoil in the summer of 1998 led to a speculative attack on the ruble which fell from 6 to 16 per dollar, and is now about 24 to the dollar (Leijonhufvud and Ruhl 1998; Selowsky and Martin 1998).

In July 1998 the IMF approved an \$11.2 billion loan, conditional on reforms that were promised in 1992, reducing the fiscal deficit, dealing with banking sector problems, and controlling government debt. The World Bank and bilateral sources promised $\$ 11.4$ billion. In August 1998 the government defaulted on $\$ 40$ billion of ruble-denominated bonds and unilaterally rescheduled the loan on confiscatory terms. The central bank suspended trading in foreign currencies indefinitely (Eichengreen 1999; Claessens, Oks, and Polastri 1998).

The IMF paid out $\$ 4.8$ billion to Russia in July 1998, an amount which disappeared into bank accounts abroad of Russian officials. The IMF then suspended the program. In May 1999, a new program was negotiated, $\$ 4.5$ billion of which was to be retained by the IMF, so that Russia 
would not default on its obligations to the IMF. The program was approved at the end of July 1999, when Russia's debt to the IMF was $\$ 17.7$ billion, about twice its quota (BIS 1999).

This approval was a condition for Russia to seek rescheduling of $\$ 30$ billion in commercial-bank debt inherited from the Soviet Union by the London Club of lenders representing more than 600 Western banks. The debts were rescheduled once in 1997, and the hope is to reschedule payments due in 1999 and 2000. Russia defaulted on the London Club debt in December 1998, when it missed a \$362 million interest payment, and two more payments totaling \$578 million in June 1999. Holders of the debt, however, decided not to declare a formal default.

In February 2000 Russia reached an agreement with foreign commercial creditors to write off about two-thirds of its debt. Under the agreement $\$ 22.2$ billion of Soviet-era debt and \$6.8 billion in Russian state debt will be exchanged for new 30-year Russian Federation eurobonds. The new bonds will be offered at a 37.5 percent discount for soviet debt and a 33 percent discount for the Russian debt. Creditors will thus get 62.5 percent of the value of the soviet debt and 67 percent of the value of the Russian debt. The Eurobonds have a grace period of 7 years and interest payments will rise gradually, from 2.25 percent for the first six months after issuance, to 7.5 percent from the eighth year to maturity.

Separate negotiations with the Paris Club of sovereign lenders who hold $\$ 40$ billion in Soviet-era government debt are slated to start later in 2000, concerning only payments due last year and next.

Before the London Club agreement was reached in February 2000, Russia began payment that month on the $\$ 1.3$ billion dollar-denominated bonds on which it defaulted in May 1999. The government swapped the debt known as Min Fin IIIs for $\$ 650$ million of new dollardenominated 8-year bonds or $\$ 672$ million of 4-year ruble debt. 
Suspicions about the true condition of Russia's finances motivated the IMF in 1999 to order an audit of the central bank by Price Waterhouse Coopers. It reported on the internet that the central bank in 1996 transferred $\$ 1.2$ billion of IMF money to a subsidiary, Financial Management Company (Fimaco), that it controlled in the Channel Islands. Transactions between the central bank and Fimaco had the effect of disguising the bank's balance sheet in violation of IMF loan requirements. The audit named a dozen other offshore subsidiaries that the central bank owns. A new inquiry into the operations of some of these subsidiaries is under way, and is to be completed by September 1999 before the IMF releases a further loan installment to Russia. While the audit found no evidence that IMF money was diverted to private use, it was not designed to explore possible malfeasance in other ways by the central bank and the government.

The audits are independent of an investigation into Russian money laundering involving the Bank of New York. IMF money may have been diverted into the Bank of New York accounts. Whether the laundered funds transferred, estimated as aggregating to $\$ 6.5$ billion, included sums from criminal activities by Russian mobsters or represented capital flight from untainted sources to evade taxes remains to be determined.

The IMF in April 2000 announced that, starting in July, each borrower central bank will be required to publish an outside audited financial statement to prevent misuse of IMF loans. One observer ( $⿱$ Aslund 2000) believes that the IMF’s role in Russia is over. Russia’s problems now are structural - it needs tax reform, land reform, and overcoming corruption - and could manage reform on its own. It may clear up its debt restructuring in 2000; it has a large trade surplus and no chronic budget deficit. At least 70 percent of GDP arises in the private sector. Once Russia convinces its citizens that the economy is stable, capital flight will end, and official international reserves will accumulate. 
The IMF's standby arrangement on December 2, 1998, with Brazil in the amount of $\$ 17.5$ billion -- unlike the arrangements with Mexico and the Asian countries, which had devalued their currencies before they obtained IMF loans -- was implemented while the Real was still linked to the dollar at the crawling peg parity instituted in 1995. Lax government fiscal policy was at the root of the market's loss of confidence in the pegged Real rate (Gruben 1999). In late January 1999 the Real slipped its peg. The IMF loan to Brazil, part of a $\$ 41.5$ billion package, was not a bailout loan, in the image of the Mexican and Asian loans, but rather a traditional currency crisis rescue. In the succeeding months the government made progress in cutting spending and raising revenue.

In April 2000, Brazil announced that it will repay early $\$ 10.3$ billion in loans due in October to the IMF, the Japanese central bank and the BIS. It had drawn about $\$ 20$ billion of the $\$ 32$ billion offered by these lenders. After the repayment, Brazil will owe the IMF $\$ 1.8$ billion and about $\$ 9.5$ billion to the World Bank and the Inter-American Development Bank. These loans are nonemergency funds that have lower interest rates and longer maturities.

Brazil's economic recovery in 1999 is linked to a $\$ 30$ billion inflow of direct foreign investment. The economy eked out nearly a percentage point of growth last year.

\section{Incidence and severity of crises}

How does the record of recent emerging market crises that elicit IMF rescues compare with that of earlier times when there was no IMF? Bordo and Eichengreen (1999) provide an answer to that question. They show the behavior of real GDP growth in a window five years before a crisis and five years after a crisis for 15 emerging countries and 6 advanced countries in the period 
1880-1913--a period when capital flowed as freely as it does today ${ }^{8}$ - compared to a sample of 10 emerging market countries experiencing crises in the past 25 years. ${ }^{9}$ Crises are defined as both currency and banking crises ${ }^{10}$ that were identified from historical narratives. In addition, as an alternative indicator of a currency crisis, Bordo and Eichengreen used an index of exchange market pressure. ${ }^{11}$ They included 22 crises in emerging market countries (and 7 in their advanced industrial counterparts) prior to 1914 . For the period since 1972, they identified 30 crises in 10 emerging market countries.

The incidence of emerging market crises today is considerably higher than in the earlier period, at $11.5 \%$ per country year versus $4.3 \%$ for the earlier period. ${ }^{12}$

\footnotetext{
${ }^{8}$ The countries, which include many of today's advanced countries, are: Argentina, Australia, Brazil, Canada, Chile, Denmark, Finland, Greece, Italy, Japan, Norway, Portugal, Spain, Sweden, and Switzerland.

${ }^{9}$ The countries are: Argentina, Brazil, Chile, Indonesia, Korea, Malaysia, Mexico, Philippines, Singapore, and Thailand.

${ }^{10}$ For an episode to qualify as a banking crisis, there had to be either bank runs, bank failures and the suspension of convertibility of deposits into currency (a banking panic), or else significant banking-sector problems (including failures) that are resolved by a fiscally-underwritten bank restructuring.

This allowed Bordo and Eichengreen to distinguish between liquidity crises before 1914 in which lender-of-lastresort intervention was either absent or unsuccessful, and events (like those typical of more recent years), where a lender of last resort or deposit insurance was in place and the main problem was bank insolvency. In fact, however, a number of banking crises which occurred in Europe before 1914 did not involve panics and in this respect were not dissimilar from episodes occurring more recently. For an episode to qualify as a currency crisis, there had to be a forced change in parity, the abandonment of a pegged exchange rate, or an international rescue.

${ }^{11}$ It is calculated as a weighted average of the percentage change in the exchange rate with respect to the core country (the UK before 1914, the US thereafter), the change in the short-term interest rate differential with respect to the core country, and the difference in the percentage change in reserves of a given country and the percentage change in reserves of the core country.

This builds on the exchange-market-pressure model of Girton and Roper (1977), following the methodology of Eichengreen, Rose and Wyplosz $(1995,1996)$.

We count an episode as a currency crisis when it shows up according to either of these indicators.

${ }^{12}$ Note however that the post-1972 sample was not selected randomly; the 10 countries considered were selected as the subjects of well-known crises. The results in the World Economic Outlook (Chapter 4, May 1988) for a larger sample of 30 emerging countries, based on a similar chronology, show the incidence to be somewhat higher than ours. This reflects a larger number of crises in the WEO sample, but the incidence of twin crises in our sample greatly exceeds that in the larger WEO sample.
} 
The measure of the severity and duration of a crisis was the extent to which the annual GDP growth rate deviated from trend on its account and then recovered. Specifically, for each country Bordo and Eichengreen calculated the growth rate in the crisis year relative to its trend over the five years preceding the crisis, crisis-year growth relative to its three-year trend preceding the crisis; the difference between crisis-year growth and the preceding year's growth rate; the difference between growth the year following the crisis and the crisis-year growth rate; the difference between the three-year trend growth rate following the crisis and the crisis-year growth rate; and finally the difference between the five-year trend growth rate following the crisis and the crisis-year growth rate.

Table 1, adapted from Bordo and Eichengreen (1999), presents summary statistics of cross-country averages of the growth rates calculated as described above for the emerging market countries for the pre-1914 and post-1972 periods. A key fact is that the output effects of banking and financial crises in emerging market countries were somewhat more severe in the recent period compared to the pre-1914 period. Whereas growth declined by 3 percentage points relative to trend in the typical post-1972 crisis, the comparable number for emerging markets in the pre-1914 period was 2 percentage points. The contrast is sharpest for twin crises (combinations of both banking and currency crises), which have been exceptionally disruptive since 1972 (when the average decline in the growth rate was 5 per cent) but were less so prior to 1914 (when the average drop was again "only" 2 percent). Whatever the contrast, however, these differences are not large. ${ }^{13}$

\footnotetext{
${ }^{13}$ While crises may have been somewhat less severe on average before 1914 than today, t-tests of the differences of means do not permit us to reject the null that the severity of downturns was the same across periods.
} 
By these measures, the fall in output in the recent Asian crisis was especially steep:

Korea's growth rate declined 7 percentage points below its pre-crisis five-year-average growth rate, 8 percentage points below its three year pre-crisis average and 7 percentage points from the year preceding the crisis. Indonesia's performance was similar, while Thailand's was the worst (at minus 13, 13, 11 percentage points respectively). See Figure 1 . The severity of these countries' crises in 1997-1998 is well known; the point here is that their recessions were dramatic relative to the typical crisis in emerging markets prior to 1914.

How does recent Asian experience compare with the worst of the pre-1914 era? The two most infamous pre-World War I crises in emerging market countries, the US in 1893 and Argentina in 1890, were even worse than Asian crises in recent years. ${ }^{14}$ For the US, growth during the crisis year declined by 9 percentage points relative to its previous five-year trend, 12 percentage points below its three-year pre-crisis trend, and 14 percentage points from the precrisis year. For Argentina the numbers are even more dramatic if the conventional statistics are to be believed: minus $17 \%, 20 \%, 24 \%$, with recovery in growth not complete after 5 years. ${ }^{15}$

The experience of the six advanced countries in the pre-1914 period in general was much more peaceful than that of the emerging market countries, with the exceptions of currency crises

\footnotetext{
${ }^{14}$ Categorizing the United States as an emerging market is likely to be controversial. Our categorization follows Eichengreen (1992), which classes the U.S. as a "peripheral" country prior to 1913 on the grounds that it was dependent on capital imports for much of the period, lacked a lender of last resort to backstop domestic financial markets, and was not fully committed to the maintenance of gold convertibility, and thus not the recipient of stabilizing capital flows. For a contrasting interpretation, see Bordo and Schwartz (1996).

${ }^{15}$ Two other famous emerging financial crises associated with serious real effects were those in Australia in 1893 and the US in 1907-08, which we show in Figure 1. The exceptional severity of these episodes should serve as a warning that generalizations about the pre-1914 period must be drawn cautiously, since that period appears to have featured a small number of extraordinarily severe crises along with numerous milder episodes. This is another way of understanding why it is difficult to reject the null that the severity of crises was the same across periods; the standard deviation of the fall in output was large, reflecting the aforementioned heterogeneity, relative to the mean, both before 1914 and after 1972 .
} 
in Germany in 1903 and 1907 associated with large drops in growth relative to trend, and severe twin crises in France in 1889 (Bordo and Eichengreen 1999, Table 1).

Table 1 also suggests that emerging market countries recovered more quickly from currency crises before 1914 than after 1972. Before 1914, the growth rate rose by 2 percentage points between the crisis year and the three years following; after 1972, the growth rate failed to rise at all. Alternatively, in the earlier period, growth three years after the crisis was 2 percentage points above that five years before the crisis, while for the recent period, it was 2 percentage points below that five years before the crisis (row 5 minus row 1). In contrast, the recovery from banking crises starts earlier in the modern period, in the first post-crisis year as opposed to the second or third. This is true whether or not banking crises were accompanied by currency crises.

Explanations for these contrasts between the pre-1914 and post-1972 era refer to a number of factors. Faster recovery before 1914 could be attributable to adherence, or attempted adherence, to the gold standard rule. Prior to 1914, countries driven off the gold standard generally intended to restore convertibility at the previously-prevailing exchange rate once the crisis passed. While investors who held domestic-currency-denominated assets suffered losses when the exchange rate collapsed, they anticipated gains as the currency recovered to its traditional parity (Miller 1996,1998). To put the point another way, insofar as the authorities were committed to reestablishing the previous rate of exchange, there was little reason to fear that abandoning the currency peg would unleash uncontrolled inflation. Hence, devaluation did not incite persistent capital flight. Rather, gold and capital began flowing back in at a relatively early date, stabilizing the economy and stimulating recovery. ${ }^{16}$

\footnotetext{
16 See Goodhart and DeLargy (1999).
} 
The slower recovery from banking crises in the early period may reflect the absence of effective lenders of last resort, capable of restoring depositor confidence, stabilizing supplies of money and credit, and sustaining the provision of financial services to the economy. The US crises of 1893 and 1907, which were greatly aggravated by the absence of last-resort lending (leading in turn to the establishment of the Federal Reserve), make this point. ${ }^{17}$

One could also argue that regulatory forbearance and central bank bailouts have adverse long-term effects by weakening market discipline and leading to a less efficient allocation of capital. Indeed, there is some suggestion of this in the data: while recovery from banking crises is initiated earlier in the post-1972 period, the subsequent expansion accelerates less dramatically and is sustained less successfully, as if market discipline and the efficiency with which credit is allocated are less pronounced (than in comparable episodes a hundred years ago).

Automatic stabilizers were also absent prior to 1914. Some recent commentators have noted that automatic stabilizers in the Asian crisis countries (and other emerging market countries) were constrained by a lack of confidence on the part of investors and the existence of high capital mobility. That may be true, but the comparison suggests that they might still have been able to adopt a more expansionary response than their counterparts a century ago. Other commentators have been critical of regulators for failing to compel an earlier resolution of banking problems. They have a point, but the striking fact is that recovery from banking crises has tended to begin earlier in the recent period than in the typical crisis episode a hundred years ago. This comparison ignores the fact that profound banking problems in the recent crisis

\footnotetext{
${ }^{17}$ So does the fact that recovery from banking crises and twin crises was on average initiated earlier in the advanced countries than in the prewar emerging market countries, given the fact that lender-of last resort capacity was more highly developed in the center.
} 
countries had not been resolved when, according to the data, recovery began, e.g., Mexico, Korea, Thailand.

Finally, the fact that the decline in real growth was greater on average in today's crises may just reflect the presence of the safety-net provided by the IMF and other IFI's. The belief that emerging market countries would be bailed out may have encouraged more capital to flow in than would have been the case in the absence of the safety net. Hence the reversal of capital flows and their effects on the real economy became more serious. ${ }^{18}$ Moreover the fact that after 80 years and the creation of these institutional safeguards the crisis problem for emerging countries seems to be as virulent as ever gives cause for some concern.

The interwar years, as is well known, were notoriously crisis-prone: the incidence of crisis per country-year was ten percent. The drop in output following crises was exceptionally sharp, for both advanced and emerging market countries, exceeding that for emerging market countries today. See Figure 1 for the pattern of real growth during the Great Depression in two famous advanced country crises during the Great Depression: the US and Germany, and two emerging market countries with serious crises: Argentina and Brazil. The difference between the interwar and the two aforementioned periods (pre-1914, and post-1972) was the exceptional severity of the banking and twin crises of the 1930s. This was of course Friedman and Schwartz's (1963) explanation for the severity of the Great Depression in the United States, which they attributed to the failure of the Federal Reserve to act as a lender-of-last-resort, in conjunction with the disappearance of the private lifeboat operations by the clearing house

\footnotetext{
${ }^{18}$ Indeed, Bordo and Eichengreen (1999) show that the swings in capital flows were larger in the recent compared to the earlier crises.
} 
associations that were so important before the war. The twin-crises version is the explanation for the exceptional depth of the global slump elaborated by Bernanke and James (1991).

Under Bretton Woods, crises were mild. There were no banking crises in our sample, reflecting the restrictions imposed on banking systems in response to the disasters of the 1930s. While currency crises continued to occur despite the adoption of restrictions on capital mobility, their output effects were mild by the standards of the pre-1914 and interwar periods. This plausibly reflects the more limited scope for capital flight in the controlled financial environment of the 1950s and 1960s, and the greater scope for central banks to continue pursuing policies to sustain output and demand behind the shelter of controls. Those recessionary effects were more pronounced in emerging market than advanced economies, but the contrast is less than in either of the preceding periods, plausibly reflecting the prevalence of capital controls and the quiescence of international financial markets.

\section{Empirical evidence on the effectiveness of IMF programs: A with-without comparison}

We first present a summary of IMF loans to emerging countries in Latin America and Asia from 1973-1998. Table 2 shows in SDRs $(1 \mathrm{SDR}=\$ 1.35)$ the sum of all IMF arrangements for each country that received such arrangements. The total includes the following: Stand-by, Extended Arrangements, Structural Adjustment, and Enhanced Structural Adjustment Arrangements. The first two categories, which are designed to deal with temporary or medium-term balance of payment difficulties, comprise the vast majority of loans for the countries in our sample. Standby loans run from 1 to 3 years, with repayments scheduled between $3 \frac{1 / 4}{4}$ and 5 years after the borrowing. The extended facility is available for a longer period of $4 \frac{1 / 2}{2}$ to 10 years. ${ }^{19}$ These

\footnotetext{
${ }^{19}$ The other two facilities, which involve highly subsidized lending, were designed for very poor countries to help them deal with the 1970 s oil crisis and to finance economic development.
} 
facilities carry an interest rate based on rates in the major industrial countries. Attached to each of these loans are conditions placed on monetary and fiscal policy of the borrower as well as other conditions. In the table we show the amounts agreed for multi-year programs spread evenly over the years of the program. ${ }^{20}$ We also show for four recent crises (Mexico, Korea, Indonesia, and Thailand) the resources offered by the US and other lenders.

Two striking patterns may be seen in the table. First, a number of countries seem perpetually to borrow from the Fund. In Latin America, these include: Argentina, Ecuador, and Peru. In Asia, the standout is the Philippines. The failure of these countries to thrive is interpreted by some observers as evidence that the Fund promotes a form of welfare dependency (Bandow and Vasquez 1994). Others point to the success stories of Chile and Korea, which relied heavily on the Fund in the 1960s and 1970s but have since emerged as relatively successful economies (Krueger 1998).

The second pattern is the enormous increase in the size of loans associated with the Mexican bailout of 1995 and the three recent rescues in Asia. The Mexican IMF package was approximately 10 times the size of the preceding loan it obtained in 1986, Indonesia's loan increased by 160 times over the last loan in the 1970's, Korea's by 25 times and Thailand's by 7 times. ${ }^{21}$

Given the scale of IMF loans, what was their effect as well as that of the conditionality that accompanied them on the economic performance of the recipients? IMF programs were

\footnotetext{
${ }^{20}$ We do not show the amount drawn, which in some cases is less than the amounts agreed. Evidence of undrawn balances at the expiration of an agreement in the past was generally regarded as evidence that the borrower did not meet the terms of the Fund's conditionality. In recent years, the decline in the ratio between actual and potential borrowing has come to be regarded as evidence that emerging countries are using access to credit from the IMF as a signal of their financial probity. See Giannini (1998) and Bordo and James (1999).

${ }^{21}$ The increase in loan size relative to IMF quotas is similar in relative magnitude.
} 
designed originally in the Bretton Woods era to provide relief to member countries facing temporary balance of payments difficulties related to the current account. It was believed that IMF resources and advice would give the members time to adjust their policies to match domestic expenditure with income, and it would not be necessary for them to alter their parity exchange rates when faced with a shock. Since the breakdown of Bretton Woods and the advent of managed floating, however, resources have been provided to allow adjustment related to either over- or undershooting of the exchange rate or the failure of the domestic economy to adjust to exchange rate movements (Masson and Mussa 1996). Resources in very recent years have also been provided to offset the deleterious effects of massive capital flows.

IMF programs have generally encouraged member countries to follow tight monetary policies to reduce inflation and to attract foreign capital or prevent its outflow, and tight fiscal policies to stimulate domestic saving as a substitute for foreign capital. From this perspective, a successful program would improve the current account and the balance of payments, arrest a depreciating exchange rate, reduce money growth and inflation, and reduce the government budget deficit. The program would achieve these aims presumably without significantly harming the real economy. What does the evidence show?

The simplest approach to this question is to compare the macroeconomic performance of countries in the same region, which received IMF assistance, with those countries supposedly facing the same external shocks, which did not. This is referred to as the With-Without approach (see Khan 1990). ${ }^{22}$ In what follows, we compare the performance, over the period 1973-99, of 10 macro aggregates (real GDP growth, level of per capita GDP, consumption/GDP, money

\footnotetext{
${ }^{22}$ An alternative approach, the Before-After approach is deemed to be severely biased because it does not account for factors other than the program that would affect economic performance (Khan 1990).
} 
growth, inflation, budget deficit/GDP, current account/GDP, nominal interest rate, nominal and real exchange rates) ${ }^{23}$ in a sample of countries in Asia and Latin America, some of which had IMF programs and some of which did not. ${ }^{24}$ Our criterion for whether a country was in the Fund or not was whether it had a program for more than 3 years. ${ }^{25}$

For each variable we show a series of figures which represent a window of five years before and after a crisis. ${ }^{26}$ The chronology of currency and banking crises is drawn from the IMF World Economic Outlook, May 1998. See Table 3, which shows the template of crises and IMF programs used to generate the figures. For each variable we made a comparison of Fund and non-Fund countries, for all countries in our sample, and separately for Latin America and for Asia. $^{27}$

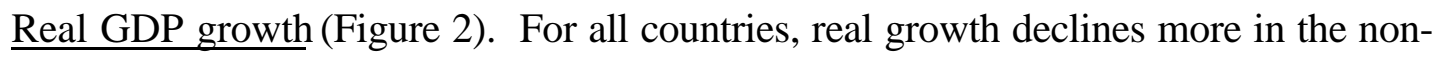
IMF countries than in the IMF countries but does not fall to quite as low a level as in the IMF

\footnotetext{
${ }^{23}$ We did not compare stock prices because of insufficient data for the Asian countries. Our data for 1998 are complete, but partial for 1999, and only for some countries.

${ }^{24}$ The Latin American countries that we identify as having IMF programs are: Argentina, Bolivia, Brazil, Chile, Ecuador, Mexico, Peru, and Uruguay. Latin American countries not having IMF programs are: Colombia, Paraguay, and Venezuela. The Asian countries with IMF program are: Korea, Philippines, Thailand, and Turkey. The Asian countries without IMF programs are: Australia, Hong Kong, Indonesia, Israel, Malaysia, Singapore, South Africa, and Taiwan.
}

${ }^{25}$ We also experimented with fewer years. For two and three years, the results are comparable to those shown here. Below two years, it reduced the number of countries in the two regions to the point that made it difficult to make a comparison, e.g., Paraguay is the only country in Latin American which has not had an IMF program since 1969.

${ }^{26}$ Crises may be currency or banking or both. A crisis that is not at least two years apart from the nearest crisis period is treated as a part of one crisis. The pre- and post-crisis behaviors of the variables of interest are studied for a period of five years.

${ }^{27}$ As a sensitivity analysis, we calculated the figures in an alternative way. We included only currency crises before 1990, and currency and banking crises in the 1990s. This alternative chronology would account for the fact, documented by Kaminsky and Reinhart (1998), that the incidence of twin crises has increased dramatically in the 1990s, and that banking crises tend to lead currency crises more than the reverse. Hence, to the extent that IMF programs have generally been designed to deal with shocks to the balance of payments, this demarcation may be closer to one consistent with the IMF's stated mission. The patterns observed, using the alternative template, are not that different from those observed in Figure 2-1. 
countries. Moreover, the recovery after the crisis is faster for the non-IMF countries but, after a year, growth converges toward the same rate in the four groups of countries. ${ }^{28}$ What is surprising from these figures, however, is not the difference between growth rates, which is small, but the fact that IMF countries do not do appreciably better than their non-IMF counterparts. In Asia, the non-IMF countries' growth rates decline more than do those for the IMF countries up to the crisis year, but then rebound much more rapidly. By contrast, the Latin American countries that do not go to the Fund do not decline as rapidly nor do they rebound as quickly. This evidence is consistent with the conventional view that an IMF program is temporarily harmful to the health of the recipient.

Per Capita Real GDP (in logs) (Figure 3). For the panel containing all countries, the nonIMF countries show a rise over the whole window from a lower level than for the IMF countries, with only a small dip during crises. By contrast the IMF countries suffer a severe drop beginning one year before and continuing one year after the crisis, then leveling out at the same pace as the other group. For Latin America, per capita income falls more in the non-IMF countries before the crisis but recovers quickly a year before the IMF countries do. For Asia, before the crisis, non-IMF countries are at a lower level than the IMF countries but exhibit only a mild decline compared to a precipitous drop in the year following the crisis in the IMF sample. Thus, like the evidence for real growth, IMF countries seem to suffer more hardship in crisis.

The Ratio of Consumption to GDP (Figure 4). For all countries consumption is at a lower level in non-IMF than IMF countries and does not decline until three years after the crisis and then only for a year. By contrast, for the IMF countries, the year after crises, consumption

\footnotetext{
${ }^{28}$ Using the alternative chronology, real growth declines more in the non-IMF countries than in the IMF countries and falls to a slightly lower level than in the non-IMF countries. Recovery is slightly faster in non-IMF than in IMF countries. However, the difference between the two crisis chronologies is negligible.
} 
levels off and declines thereafter. For Latin America, non-IMF countries exhibit a slight decline in $\mathrm{C} / \mathrm{Y}$ in the year after the crisis, while the IMF countries exhibit falling rates continuously a year after the crisis. Finally, the Asian IMF countries exhibit a decline in $\mathrm{C} / \mathrm{Y}$ beginning two years after the crisis. Like Latin America, the non-IMF countries experience a brief decline in $\mathrm{C} / \mathrm{Y}$ three years after the crisis. As for real GDP, an IMF program, after the package is implemented, seems to be associated with a decline in consumption and hence living standards, albeit a rise in savings. Thus, IMF austerity by raising savings to compensate for the loss of foreign capital suggests that it may have smoothed the adjustment needed to offset the imbalances leading to crisis.

Current Account to GDP ratio (Figure 5). For all countries, the current account deficit declines much more in the non-IMF countries, with a major current account reversal two years before the crisis. For the Fund countries, the reversal, which is less prominent, occurs the year before the crisis. For Latin America, the pattern is similar to that for the all-countries' sample. For Asia, the non-IMF pattern is the same as for Latin America. The IMF pattern differs in that the decline and reversal are centered on the crisis year. The pattern for the current account seems consistent with the conventional view: IMF programs may have smoothed the adjustment of the current account. It also is consistent with the view that the current account reflects prior policy imbalances leading to crisis and a request for aid from the IMF.

Inflation (Figure 6). For all countries and for Latin America the pattern is dramatic. IMF countries experience a tremendous rise in the inflation rate until the crisis and then a precipitous drop. For the non-IMF countries, partly because of the scale, there is virtually no movement. By contrast to inflation-prone Latin Americans, the IMF Asian countries had higher inflation than the non-IMF countries with both declining the year before the crisis. After the crisis, non-IMF countries had a temporary uptick in inflation and then a steady decline. Like the current account, 
the picture is consistent with the conventional wisdom: IMF programs are associated with a decline in inflation. They also are consistent with the view that high inflation countries are crisis prone and are likely to turn to the IMF.

Money Growth (Figure 7). The picture for money growth for all countries and for all Latin America mirrors that of inflation-for IMF countries there is a runup to the crisis followed by a collapse. For the non-IMF countries, partly because of the scale, a much milder but similar pattern may be detected. For the Asian countries, it is the non-IMF countries that exhibit the runup in money growth to the crisis and then the decline. IMF countries exhibit declining money growth up to the crisis, followed by mild, then rapid recovery. To the extent the reversal in money growth reflects IMF programs, the Latin American experience fits the prescription. But it is not evident for the Asians. Also the Latin Americans fit the bill for countries that turn to the IMF for aid after excessive credit expansion has led to a crisis.

Budget Deficit Relative to GDP (Figure 8). For all countries, the budget deficit rises significantly for IMF countries up to the crisis and then reverses. A more muted pattern is observed for the non-IMF countries, with one significant difference: after three years, the deficit increases again. For Latin America we observe a similar pattern, except that the non-IMF countries go into surplus temporarily the year after the crisis. They also exhibit a substantial reversal after the crisis, which is not the case for non-IMF countries. This evidence is consistent with the conventional wisdom: IMF programs are associated with improved fiscal discipline. It is also consistent with the view that profligate countries turn to the IMF.

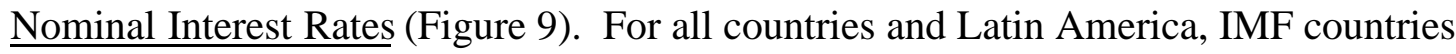
exhibit a sharp runup in nominal interest rates up to the crisis and then a rapid decline. By contrast, non-IMF countries with much lower rates exhibit little detectable movement. This pattern of course reflects the behavior of inflationary expectations incorporated into interest 
rates. For the lower inflation Asian countries, rates in the IMF countries rise slightly before the crisis and considerably afterwards. This is in sharp contrast to the non-IMF countries, where interest rates decline continuously beginning the year before the crisis. This pattern is evidently consistent with the conventional view that the IMF programs involve tight money policies.

Nominal Exchange Rates (Figure 10). For all the countries in our sample and for Latin America, IMF countries show rapidly rising exchange rates until the crisis year, when they collapse. A much more muted but similar pattern holds for the non-crisis countries. This pattern, similar to those in Figures 6, 7, 8, and 9, reflects the classic first generation speculative attack explanation for currency crisis that emphasize fiscal profligacy and inflation. By contrast for the Asian countries, with much lower inflation rates, non-IMF countries exhibit a slightly greater depreciation of the exchange rate up to the crisis and then a temporary appreciation, while IMF countries exhibit depreciation until a year after the crisis, followed by a steady appreciation. This pattern suggests that Fund programs were ultimately successful in preventing a collapse of the currency. It also suggests that countries that turn to the IMF are more crisis prone.

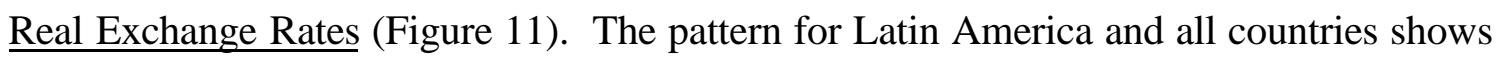
a much larger real depreciation of the exchange rate before the crisis in IMF countries compared to non-IMF countries, followed by a much more rapid real appreciation in the former. A similar but less marked pattern prevails for the Asian countries. The same conclusions hold as for the nominal exchange rate.

In sum, the crisis windows patterns do not yield too many surprises. Before a currency crisis, IMF countries on average exhibit, relative to their non-IMF counterparts, faster money growth, larger fiscal deficits, higher inflation rates, and greater depreciation in their exchange rates, with greater reversals of all of these variables afterwards. Also, IMF programs seem to be 
associated with tight money, rising interest rates, declining fiscal deficits, and current account reversals, as they were meant to do. But the outcome seems to be lower real growth (at least temporarily), lower real per capita GDP, and lower consumption, which may be a necessary consequence of the medicine administered. A question still remains, however, in assessing the impact of the IMF programs: what would have happened in the absence of the IMF? Would the patterns we have observed have been the same? In Section 7, we attempt to provide at least a partial answer to that question.

\section{Empirical evidence on the effectiveness of IMF programs: A counterfactual analysis}

In Section 6, we compared the behavior of 10 macro aggregates in a 10-year window surrounding crises in IMF and non-IMF countries in Asia and Latin America. That analysis only goes part way in allowing us to assess the impact of IMF programs. A proper counterfactual analysis needs to account for the policies that would have been followed in the absence of IMF intervention and it also needs to account for the self-selection bias, namely, that countries that tend to run large fiscal deficits and rapid monetary expansion, as well as having other characteristics, such as an unsound banking system, will turn to the IMF more readily than countries without these characteristics.

In this section we estimate a model of the impact of IMF programs on several key policy variables (real GDP growth, inflation, the current account, and the balance of payments), adjusting for alternative policies and self-selection bias. We follow the approach taken by Goldstein and Montiel (1986), Khan (1990), Ul Haque and Khan (1998) and Conway (1994). 
We then estimate the model for 11 Latin American and 13 Asian countries, using annual data 1973-1998 and quarterly data for a smaller group of countries $1985-1998 .^{29}$

\subsection{Methodology to isolate the economic impact of IMF assistance}

Suppose the $j$ th target variable in country $i$ at time $t$ is denoted by $\mathrm{y}_{\mathrm{ijt}}$. This target variable is determined according to the following equation:

$$
y_{i j t}=\beta_{0 i j}+X_{i t}^{\prime} \beta_{j}+W_{t}^{\prime} \alpha_{j}+d_{i t} \beta_{j}^{I M F}+\varepsilon_{i j t}
$$

where $\mathrm{y}_{\mathrm{ijt}}$ is the policy target (the growth rate, the current account, the balance of payments, and the inflation rate). $\mathrm{X}_{\mathrm{it}}$ is a $\mathrm{P} \times 1$ vector of policy instruments (including domestic credit expansion, the exchange rate, and the fiscal deficit) and $\mathrm{W}_{\mathrm{t}}$ is an $\mathrm{M} \times 1$ vector of foreign exogenous variables (including the foreign interest rate). $d_{t}{ }^{i}$ is a dummy variable, which takes the value of 1 if a country is in an IMF funded program and the value of 0 otherwise.

The interpretations of the coefficients in equation (1) are as follows: $\beta_{0 \mathrm{ij}}$ is a constant, $\beta_{\mathrm{j}}$, $\alpha_{j}$, are the coefficients associated with the domestic policy instruments and foreign exogenous variables. The coefficients $\beta_{0 \mathrm{ij}}, \beta_{\mathrm{j}}, \alpha_{\mathrm{j}}$ are assumed to be the same for all countries.

While we can observe the domestic policy of those countries that are not in an IMF program, we do not know what domestic policy the countries in an IMF program would have followed, if the IMF had not intervened. To handle this problem we introduce a government reaction function. Khan (1990) and Goldstein and Montiel (1986) propose this approach which is called the Generalized Evaluation Estimator (GEE).

$$
\Delta X_{i t}=\theta\left[Y_{i}^{d}-Y_{i, t-1}\right]+\eta_{i t}
$$

\footnotetext{
${ }^{29}$ Earlier studies, surveyed in Ul Haque and Khan (1998), covered different samples of countries for periods ending in 1992.
} 
where $\mathrm{Y}_{\mathrm{i}, \mathrm{t}-1}$ is the vector of target variables, $\mathrm{Y}_{\mathrm{i}}{ }^{\mathrm{d}}$ is the desired value of these target variables and $\theta$ is a matrix of adjustment parameters. It is assumed in the following analysis that the objectives of the authorities of all countries are summarized in equation (2). ${ }^{30}$

By substituting (2) in (1) we can rewrite the equation to be estimated as

$$
y_{i j t}=\left(\beta_{0 i j}+Y_{i}^{d}{ }^{\prime} \theta^{\prime}\right)-Y_{i, t-1}^{\prime} \theta^{\prime} \beta_{j}+X_{i, t-1}^{\prime} \theta^{\prime} \beta_{j}+W_{t}^{\prime} \alpha_{j}+d_{i t} \beta_{j}^{I M F}+\left(\varepsilon_{i j t}+\eta_{i t}^{\prime} \beta_{j}\right) .
$$

We can re-write the above more compactly as follows

$$
\mathrm{y}_{\mathrm{ijt}}=\mathrm{Z}_{\mathrm{t}} \Theta+\mathrm{d}_{\mathrm{it}} \beta_{\mathrm{j}}^{\mathrm{IMF}}+\xi_{\mathrm{ijt}}
$$

where predetermined, policy and other exogenous variables have been combined into $Z_{t}$.

Estimation of (4) takes care of the problems identified in the literature with the beforeafter and with-without estimators, by accounting for the policies that would have been followed by countries without an IMF program. If the sample of countries going to the IMF is nonrandom, then estimation of equation (4) will suffer from a sample selection bias. We then estimate the determinants of a country's decision to go to the IMF for help. Ul Haque and Khan (1998) suggest the following two-step procedure: Define a variable called CRISIS denoted by $\mathrm{F}_{\mathrm{t}}^{\mathrm{i}}$ which depends on a variety of domestic factors, which we include in vector ' $\omega$ '.

$$
\mathrm{F}_{\mathrm{it}}=\omega_{\text {it }} \gamma+\mathrm{u}_{\mathrm{it}}
$$

where $\mathrm{u}_{\mathrm{it}}$ is assumed to be $\mathrm{N}\left(0, \sigma_{\mathrm{u}}{ }^{2}\right)$.

$$
\begin{array}{ll}
\mathrm{d}_{\mathrm{it}}=1 & \text { if } \mathrm{F}_{\mathrm{it}}>\mathrm{F}^{*} \\
\mathrm{~d}_{\mathrm{it}}=0 & \text { otherwise }
\end{array}
$$

\footnotetext{
${ }^{30}$ This is a crucial assumption and an alternative argument could be made that the authorities of countries that do not go to the IMF may have political reasons for not doing so.
} 
Step 1 is then a probit estimation with equation (5). We calculate the probit selectivity variable $\lambda$, where

$\lambda_{\text {it }}=\phi\left(\omega_{\text {it }} \gamma\right) / \Phi\left(\omega_{\text {it }} \gamma\right)$

Step 2 tests for the significance of the $\beta_{\mathrm{j}}^{\mathrm{IMF}}$ in equation $(6)^{31}$.

$$
y_{i j t}=Z_{t} \Theta+d_{i t} \beta_{j}{ }^{\mathrm{MF}}+c \lambda_{i t}+e_{i j t}
$$

where $\mathrm{c}=\rho \sigma_{\mathrm{u}}$. $\rho$ is the correlation between $\mathrm{u}_{\mathrm{it}}$ and $\varepsilon_{\mathrm{ijt}}$.

In our work we introduce into the probit equation (5), variables which explain the crises in recent years such as the size and maturity composition of external debt, the liabilities of the domestic financial sector, and the growth of domestic credit. These variables are, in addition to the variables which determine crises and hence a decision to participate in the Fund, foreign exchange reserves, the real exchange rates, and GDP growth. See Table 4 for the list of variables. We then isolate the effect of the IMF packages on the target variables.

\subsection{Results: Annual Data}

We estimate the model described in Section 7.1 for 11 Latin American and 13 Asian countries using annual data 1973-1998. ${ }^{32}$ Table 5 shows the Probit estimation of the determinants of participation in an IMF program. The results indicate that having an IMF program in the previous year has a positive and significant effect on the probability that a country will turn to the Fund. Other things equal, there is a greater probability that Latin American countries rather than Asian countries will turn to the IMF. Rapid real growth rates and

\footnotetext{
${ }^{31}$ Conway (1994) follows a similar type of estimation. He defines participation variables, which measure the degree of a country's participation in an IMF program and does a Tobit estimation of equation (4). Bagci and Perraudin (1997) carry out simultaneous equation estimation (full information MLE) of equations (4) and (5) as opposed to Khan's two-stage method. We did not extend the estimation to 1999 because we did not have sufficient annual data to do so.
} 
ample foreign exchange reserves reduce the probability of going to the IMF, while a declining real exchange rate, a banking system with excessive liabilities, and lagged growth of real domestic credit increase the chances. ${ }^{33}$

We derive OLS estimates of equation (6), using White's estimator for the standard errors, to assess the impact of IMF participation on the four key policy targets treated in the literature: real GDP growth, the current account, the balance of payments, and the inflation rate. The results are in Table 6, panels A through D.

Our results do not differ much from the findings surveyed in UL Haque and Khan (1998). An IMF program has a negative but insignificant effect on real growth on impact but a positive and significant effect a year later. ${ }^{34}$ An IMF program has a positive but insignificant impact effect on the current account and the balance of payments. ${ }^{35}$ Finally participation in an IMF program seems to have no significant effect whatever on inflation, which is largely explained by money growth, a result echoed in other studies.

These annual results suggest that the main benefit of turning to the IMF is an improvement in the current account. The main detriment is a temporary reduction in real growth.

The fact that our results are quantitatively not as strong as those found, for example, by Conway (1994) and Bagci and Perraudin (1997), although qualitatively similar, may reflect the

\footnotetext{
${ }^{32}$ The Latin American countries in our survey are: Argentina, Bolivia, Brazil, Chile, Columbia, Ecuador, Mexico, Paraguay, Peru, Uruguay, and Venezuela. The Asian countries are: Australia, Hong Kong, Indonesia, Israel, Korea, Malaysia, New Zealand, Philippines, Singapore, South Africa, Taiwan, Thailand, and Turkey.

${ }^{33}$ Although CGRLAG has a very high p value, its inclusion makes the fit of the model much better.

${ }^{34}$ In the literature surveyed, the impact coefficient on real growth is usually negative and significant. When we estimate equation (6) excluding the selection bias variable (IMFS), which has a p value of .45, real growth is also negative and significant on impact.

${ }^{35}$ Again omitting the selection bias variable makes this coefficient significant.
} 
use of different samples. We focused entirely on emerging countries while the other studies include a large number of very poor countries which depend even more on IMF assistance. With annual data, and limited degrees of freedom, we were unable to determine whether there was a change in the effect of a Fund program after the Mexican crisis in 1994. For this purpose we next turn to quarterly data.

\subsection{Results: Quarterly Data}

In this section we estimate the model described in Section 7.1 for two periods 1973-1998 and 1986-1998. The latter period allows us to include in the probit stage the ratio of short-term foreign debt to total foreign debt as a measure of the exposure of the financial system to a rollover debt crisis. The data from the BIS are available only since 1986.

Table 7 shows the probit estimation of the determinants of participation in an IMF program. Panel A covers the period 1973I-1998IV and includes the same variables as in Table 5. In general the model's fit is quite good and buttresses the findings in Table 5. If a country holds high foreign exchange reserves and has rapid growth of real GDP (both current and lagged) the probability that it will go to the IMF is reduced. Rapid growth of real domestic credit, the lagged value of banking sector liabilities, past IMF assistance, particularly for Latin American countries, all increase the probability of going to the IMF. ${ }^{36}$ Panel B presents the probit for the shorter period 1986-1998. As in Panel A, all the explanatory variables have the posited sign and are significant.

Of great interest is the fact that the ratio of short-term foreign debt to total foreign debt is positive and highly significant. This suggests that countries that have a high proportion of short-

\footnotetext{
${ }^{36} \mathrm{We}$ also included devaluation of the real exchange rate as a determinant of IMF participation. In every specification tried, it was insignificant. This result may reflect the attempt by potential participants to first defend their pegs by running down their foreign reserves and subsequently devaluing.
} 
term foreign debt are likely to experience a financial crisis and then turn to the IMF, as was the case in the recent Mexican and Asian crises.

We estimate equation (6) using OLS and correcting for White standard errors in Table 8. For the 1973-1998 sample in Panel A, an IMF program has a negative and contemporaneously significant effect on real growth, which becomes positive after four quarters.

A dummy variable for 1995 I to account for a possible regime switch after the Mexican crisis is negative and significant. This suggests that an IMF program since that date has worsened the real growth of participants. ${ }^{37}$ For the 1986-1998 sample, including the short-term debt variable in the probit stage, yields results similar to those for the larger sample; however, the impact effect of IMF participation though negative is insignificant and the dummy variable for a regime switch though negative is less significant with a $\mathrm{p}$ value of 0.17 .

In Panel B, for the 1973-1998 sample, an IMF program has a negative and significant impact on the current account which turns positive and significant by the fourth quarter. The dummy for a regime change in $1995 \mathrm{I}$ is positive and significant, which suggests that while an IMF program has a negative impact on the current account, it has become less so since the Mexican crisis. The results are similar for the shorter sample beginning in 1986 in which account is taken of the maturity of foreign debt.

An IMF program has no significant effect on either the balance of payments or the inflation rate in either sample (see Panels $C$ and D). The latter variable seems to be explained entirely by money growth.

\footnotetext{
37 The dummy becomes significant and positive after 3 lags, however. The results were quite similar using 1994IV and 1995II as the regime switch dates.
} 
In sum, the quarterly data reinforce the impression given by the annual data - that turning to the IMF may be harmful to a country's real economic performance, once account is taken of the self-selection bias, and that this effect has been amplified since the Mexican crisis. It also suggests, in contrast to the annual results, that an IMF program does not improve the current account until some time has passed. These two findings differ from the earlier literature. They suggest that perhaps the recent spate of rescues may be the case of the medicine doing more harm than good. ${ }^{38}$

\section{Conclusion}

Both domestic and international financial crises have been a feature of economies since modern times. The severity of recent crises, however, seems to have been greater than during the era of globalization before 1914 though perhaps not compared to the 1930s. Rescue loans were made during earlier financial crises but they were not provided by international organizations in a systematic or cooperative way. Loans currently are significantly larger than in the past and they may have accentuated both the incidence and severity of financial crises.

In the belief that loans will be available from both domestic and international authorities, borrowers and lenders have let down their guard and assumed risks without the degree of caution that would have prevailed in the absence of these resources. Were these resources not available, global capital markets nowadays are broad and deep enough to provide assistance when needed

\footnotetext{
${ }^{38}$ In response to comments received after the conference we reran the quarterly regressions using available data for 1999 for a number of countries. The results were not very different from those reported here. We also ran the regressions shown in Table 8 using the basic Within-Without estimator which excludes the government reaction function and the sample selection indicator. We then tried it with just the reaction function. The results in both cases were similar to those reported but considerably weaker. Finally we excluded lagged IMF values from the probit stage of the regressions. The one notable change from the results presented in Table 8 is that now there is little evidence for a regime switch in 1994/1995.
} 
with fewer negative consequences but obviously at penalty rates of interest. In this environment, crises would still occur, losses would still be incurred, and hardships suffered but they would be recognized as the price of indiscipline.

The recent crises have stimulated a flood of proposals to reform the international financial architecture. The proposals range from enhancing the IMF's resources to transforming it into an omnipotent crisis manager to restricting its role to that of a lender to creditworthy sovereign borrowers. In addition, much attention has focused on private sector burden-sharing, improving workouts, emphasizing transparency, provision of more timely and comprehensive data, and strengthening the financial institutions of member countries.

Although many of these proposals have merit, they basically concern marginal aspects of the existing international financial system. The goal of reform should be broader. Just as national economies worldwide have learned that market-based arrangements are superior to centralized, directed economic measures, so also would the international financial system benefit from a change in direction to greater reliance on capital markets.

Many would argue that reliance on capital markets to provide assistance to countries in financial distress is Panglossian because liquidity crises would occur that paralyzed the financial system. In our view, the last liquidity crisis the world faced was in 1931. That catastrophe was the product of bad monetary policy by the advanced countries and a flawed exchange rate regime. Monetary authorities have since learned from their mistakes, and the world is no longer on a fixed rate regime. Sound macroeconomic policy by individual countries and floating exchange rates are insurance against liquidity crises. 


\section{References}

Åslund, A. (2000). Russia and the International Financial Institutions. Paper prepared for the International Financial Institutions Advisory Commission. (mimeo.)

Bagci, P., and Perraudin, W., (1997). Do IMF Programs Work?, Global Economic Institutions Working Paper.

Bandow, D., and Vasquez(1994). Perpetuating Poverty: The World Bank, the IMF, and the Developing World. Cato Institute, Washington, D.C.

Bank for International Settlements (BIS), (1999). $69^{\text {th }}$ Annual Report, Basle.

Bernanke, B., and James, H., (1991). The Gold Standard, Deflation, and Financial Crisis in the Great Depression: An International Comparison. (Ed.) R. Glenn Hubbard, Financial Markets and Financial Crises, Chicago: University of Chicago Press, pp. 33-68.

Bordo, M.D., (1993). The Bretton Woods International Monetary System: A Historical Overview. (Eds.) M.D. Bordo and B. Eichengreen, A Retrospective on the Bretton Woods System, University of Chicago Press, Chicago.

Bordo, M.D., Edelstein, M., and Rockoff, H., (1999). Was Adherence to the Gold Standard a Good Housekeeping Seal of Approval During the Interwar Period? Unpublished paper, Rutgers University.

Bordo, M.D., and Eichengreen, B., (1999). Is Our International Economic Environment Unusually Crisis Prone? Unpublished paper, Reserve Bank of Australia Conference, Sydney.

Bordo, M.D., Eichengreen, B. and Irwin, D.A., (1999). Is Globalization Today Really Different Than Globalization a Hundred Years Ago? Unpublished paper, Brookings Trade Policy Forum.

Bordo, M.D., and James, H., (1999). The International Monetary Fund: Its Present Role in Historical Perspective, U.S. Congressional International Institution Advisory Commission, Washington, D.C.

Bordo, M.D., and Kydland, F., (1996). The Gold Standard as a Commitment Mechanism, (Eds.) T. Bayoumi, B. Eichengreen, and M. Taylor, Modern Perspectives on the Gold Standard, Cambridge: Cambridge University Press.

Bordo, M.D., Mizrach, B., and Schwartz, A.J., (1998). Real Versus Pseudo-International Systemic Risk: Lessons from History. Review of Pacific Basin Financial Markets and Policies 1: $31-58$.

Bordo, M.D., and Schwartz, A.J., (1996a). The Operation of the Specie Standard: Evidence for Core and Peripheral Countries. (Eds.) J. Braga de Macedo, B. Eichengreen, and J. Reis, Currency Convertibility: The Gold Standard and Beyond, London: Routledge, pp. 11-83. 
Bordo, M.D. and Schwartz, A.J., (1996b). Why Clashes Between Internal and External Goals End in Currency Crises, 1797-1994, Open Economies Review, 7: 437-468.

Bordo, M.D. and Schwartz, A.J., (1999). Under What Circumstances, Past and Present, Have International Rescues of Countries in Financial Distress Been Successful? Journal of International Money and Finance 18: 683-708.

Boughton, J., (1999). From Suez to Tequila: The IMF as Crisis Manager. Economic Journal 80: $1-19$.

Bowe, M., and Dean, J.W., (1997). Has the Market Solved the Sovereign-Debt Crisis?

Princeton Studies in International Finance 83, Princeton.

Buiter, W.H., and Sibert, A.C., (1999). UDROP: A Small Contribution to the New International Architecture. International Finance 2: 227-247.

Calomiris, C.W., (1999). Victorian Perspectives on the Banking Collapse of the 1980 and 1990s. Unpublished paper, Columbia University.

Calomiris, C.W., and Mason, J.R. (1997). The Origin of Banking Panics: Models, Facts, and Bank Regulation. (Ed.) R.G. Hubbard. Financial Markets and Financial Crises, University of Chicago Press, Chicago.

Capie, F., (1998). Can There Be an International Lender of Last Resort? International Finance 1: 311-325.

Claessens, S., Oks, D., and Polastri, R., (1998). Capital Flows to Central and Eastern Europe and Former Soviet Union. Unpublished paper, EBRD Transition Report.

Conway, P., (1994). IMF Lending Programs: Participation and Impact, Journal of Development Economics 45: 365-391.

Corsetti, G., Pesenti, P., and Roubini, N., (1998). What Caused the Asian Currency and Financial Crisis? Banca D’Italia. Temi di Discussione del Servizio Studi, No. 343.

Davis, L.E., and Gallman, R., (1999). Waves, Tides, and Sandcastles: The Impact of Foreign Capital Flows on Evolving Financial Markets in the New World, 1865-1914. Unpublished paper, CalTech and U. North Carolina, Chapel Hill.

DeGregorio, J., Eichengreen, B., Ito, T., and Wyplosz, C.W., (1999). An Independent and Accountable IMF. Unpublished paper, Geneva Report on the World Economy 1.

Dooley, M., (1997). A Model of Crises in Emerging Markets. NBER Working Paper \#6300.

Edwards, S. (1997). The Mexican Peso Crisis: How Much Did We Know? When Did We Know It? NBER Working Paper \#6334.

Edwards, S. (1998). Capital Flows, Real Exchange Rates, and Capital Controls: Some Latin American Experiences. NBER Working Paper \#6800. 
Edwards, S. (1999). On Crisis Prevention: Lessons from Mexico and East Asia. NBER Working Paper \#7233.

Eichengreen, B., (1992). Golden Fetters: The Gold Standard and the Great Depression 19191939, New York: Oxford University Press.

Eichengreen, B., (1999). Toward a New International Architecture: A Practical Post-Asian Agenda. Institute for International Economics, Washington, D.C.

Eichengreen, B., and Lindert, P.H., (1989). Overview. (Eds.) B. Eichengreen and P.H. Lindert, The International Debt Crisis in Historical Perspectives, MIT Press, Cambridge.

Eichengreen, B., and Portes, R., (1989). After the Deluge: Default, Negotiation, and Readjustment During the Interwar Years. (Eds.) B. Eichengreen and P.H. Lindert. The International Debt Crisis in Historical Perspective, MIT Press, Cambridge.

Eichengreen, B. and Portes, R. (2000). Debt Restructuring With and Without the IMF. Paper prepared for the International Financial Institutions Advisory Commission.

(mimeo.)Eichengreen, B., Rose, A., and Wyplosz, C., (1995). Exchange Market Mayhem: The Antecedents and Aftermath of Speculative Attacks, Economic Policy 21: 249-312.

Eichengreen, B., Rose, A., and Wyplosz, C., (1996). Speculative Attacks on Pegged Exchange Rates: An Empirical Exploration with Special Reference to the European Monetary System, (Eds.) M. Canzoneri, W. Ethier, and V. Grilli, The New Transatlantic Economy, New York: Cambridge University Press.

Ford, A.G., (1962). The Gold Standard, 1880-1914: Britain and Argentina, Clarendon Press, Oxford.

Friedman, M. and Schwartz, A.J., (1963). A Monetary History of the United States 1867-1960, Princeton University Press, Princeton.

Giannini, C., (1999). Enemy of None but a Common Friend of All? An International Perspective on the Lender-of-Last-Resort Function, Princeton Essays in International Finance No. 214, Princeton.

Girton, L. and Roper, D., (1997). A Monetary Model of Exchange Market Pressure Applied to Postwar Canadian Experience, American Economic Review 67: 537-48.

Gold, J., (1988). Mexico and the Development of the Practice of the International Monetary Fund, World Development 16: 127-142.

Goldstein, M., and Montiel, P., (1986). Evaluating Fund Stabilization Programs with Multicountry Data: Some Methodological Pitfalls, IMF Staff Papers 33: 304-344.

Goodhart, C., (1987). Why Do Banks Need a Central Bank? Oxford Economic Papers 39: 7589. 
Goodhart, C., and Delargy, P.J.R., (1998). Financial Crises: Plus ça Change, Plus c'est La Même Chose. International Finance 1: 261-287.

Gorton, G., (1985). Clearing Houses and the Origins of Central Banking in the U.S., Journal of Economic History 45: 277-283.

Gruben, W.C., (1999). Brazil: Anatomy of a Crisis. Unpublished paper, Federal Reserve Bank of Atlanta.

International Monetary Fund, (1998). World Economic Outlook, Washington, D.C.

James, H., (1996). International Monetary Cooperation Since Bretton Woods. International Monetary Fund and Oxford University Press, Washington, D.C., New York, and Oxford.

Jorgensen, E., and Sachs, J., (1989). Default and Renegotiation of Latin American Foreign Bonds in the Interwar Period. (Eds.) B. Eichengreen and P.H. Lindert, The International Debt Crisis in Historical Perspective, MIT Press, Cambridge.

Kaminsky, G. and Reinhart, C. (1998). The Twin Crises: The Causes of Banking and Balance of Payments Problems, American Economic Review 89:473-500.Kane, E.J., (1998). Role of Offshore Financial Regulatory Competition in Asian Banking Crises. Unpublished paper, Boston College.

Kaufman, G.G., (1994). Bank Contagion: A Review of the Theory and Evidence. Journal of Financial Services Research 8: 123-150.

Khan, M.S., (1990). The Macroeconomic Effects of Fund-Supported Adjustment Programs, IMF Staff Papers 27:195-231.

Krueger, A.O., (1998). Whither the World Bank and the IMF? Journal of Economic Literature 36: 1983-2020.

Krueger, A., and Tornell, A., (1999). The Role of Bank Restructuring in Recovering from Crises: Mexico, 1995-98. NBER Working Paper \#7042.

Leijonhufvud, A., and Ruhl, C., (1997). Russian Dilemmas. American Economic Review 87: 344-348.

Levy-Leboyer, M., (1982). Central Banking and Foreign Trade: The Anglo-American Cycle in the 1930s. (Eds.) C.P. Kindleberger and J.P. Laffargue, Financial Crises: Theory, History, and Policy, Cambridge University Press, New York.

Lindert, P.H., and Morton, P.J. (1989). How Sovereign Debt Has Worked. (Eds.) J.D. Sachs, Developing Country Debt and Economic Performance: The International Financial System, University of Chicago Press,Chicago.

Marichal, C., (1989). A Century of Latin American Debt Crises, Princeton University Press, Princeton. 
Marshall, D., (1999). Understanding the Asian Crisis: Systemic Risk as Coordinator Failure. Economic Perspectives, Federal Reserve Bank of Chicago.

Masson, P., and Mussa, M., (1990). The Role of the IMF: Financing and its Interactions with Adjustment and Surveillance, IMF Pamphlet Series No. 50.

Meltzer, A.H., (1983). A Way to Defuse the World Debt Bomb. Fortune 108: 137-141.

Miller, V., (1996). Exchange Rate Crises with Domestic Bank Runs: Evidence from 1890s, Journal of International Money and Finance 17: 2.

Miller, V., (1998). Domestic Bank Runs and Speculative Attacks on Foreign Currencies, Journal of International Money and Finance 17: 2.

Moulton, H.G., and Pasvolsky, L., (1932). War Debts and World Prosperity, Brookings, Washington, D.C.

Obstfeld, M., (1994). The Logic of Currency Crises. NBER Working Paper \#4640.

Organization for Economic Cooperation and Development (OECD), (1995). Economic Surveys: Mexico, Paris.

Radelet, S. and Sachs, J., (1998). The Onset of the East Asian Financial Crises. Unpublished paper, Harvard University.

Schwartz, A.J. (1989). International Debts: What's Fact and What's Fiction. Economic Inquiry (January 1989):1-19.

Schwartz, A.J., (1996). Real and Pseudo-Financial Crises, (Eds.) F. Capie and G.E. Wood, Financial Crises and the World Banking System, Macmillan, London.

Schwartz, A.J., (1998). Asian Banking Crises in the 1990s: All Alike? (Ed.) G.G. Kaufman, Research in Financial Services: Private and Public Policy 10, JAI Press, Stamford.

Selowsky, M., and Martin, R. (1997). Policy Performance and Output Growth in the Transition Economies. American Economic Review 87: 349-353.

Tobin, J., (1978). A Proposal for International Monetary Reform, Eastern Economic Journal 4: 153-159.

Todd, W.F., (1999). Latin America, Asia, and Russia: Have the Lessons Been Learned? Unpublished paper, Western Economic Association Annual Meeting.

Ul Haque, N., and Khan, M., (1998). Do IMF Supported Programs Work? A Survey of CrossCountry Empirical Evidence. IMF Working Paper WP/98/169. 
Table 1

Fluctuations in Annual Growth Rates Around the Time of Crises: Summary Statistics 1880-1913, 1973-1998: Emerging and Advanced Countries

All Crises: mean (number of crises)

\begin{tabular}{|c|c|c|}
\hline & $\begin{array}{c}\text { 15 Emerging } \\
\text { Countries }\end{array}$ & $\begin{array}{c}\text { 10 Emerging } \\
\text { Countries }\end{array}$ \\
\hline & $1880-1913(22)$ & $1973-1998(30)$ \\
\hline $\mathrm{g}_{\text {crisis }}-\mathrm{g}_{(-5)}$ & -0.02 & -0.03 \\
\hline $\mathrm{g}_{\text {crisis }}-\mathrm{g}_{(-3)}$ & -0.01 & -0.03 \\
\hline $\mathrm{g}_{\text {crisis }}-\mathrm{g}_{(-1)}$ & -0.02 & -0.03 \\
\hline $\mathrm{g}_{(+1)}-\mathrm{g}_{\text {crisis }}$ & -0.02 & 0.02 \\
\hline $\mathrm{g}_{(+3)}-\mathrm{g}_{\text {crisis }}$ & 0.01 & 0.02 \\
\hline $\mathrm{g}_{(+5)}-\mathrm{g}_{\text {crisis }}$ & 0.03 & 0.03 \\
\hline
\end{tabular}

Twin Crises: means (number of crises)

\begin{tabular}{|c|c|c|}
\hline & $\begin{array}{c}\text { 15 Emerging } \\
\text { Countries }\end{array}$ & $\begin{array}{c}\text { 10 Emerging } \\
\text { Countries }\end{array}$ \\
\hline & $1880-1913(9)$ & $1973-1998(14)$ \\
\hline $\mathrm{g}_{\text {crisis }}-\mathrm{g}_{(-5)}$ & -0.02 & -0.05 \\
\hline $\mathrm{g}_{\text {crisis }}-\mathrm{g}_{(-3)}$ & -0.02 & -0.05 \\
\hline $\mathrm{g}_{\text {crisis }}-\mathrm{g}_{(-1)}$ & -0.02 & -0.05 \\
\hline $\mathrm{g}_{(+1)}-\mathrm{g}_{\text {crisis }}$ & 0.00 & 0.03 \\
\hline $\mathrm{g}_{(+3)}-\mathrm{g}_{\text {crisis }}$ & 0.01 & 0.05 \\
\hline $\mathrm{g}_{(+5)}-\mathrm{g}_{\text {crisis }}$ & 0.02 & 0.05 \\
\hline
\end{tabular}


Table 1 Continued

Banking Crises: means (number of crises)

\begin{tabular}{|c|c|c|}
\hline & $\begin{array}{c}\text { 15 Emerging } \\
\text { Countries }\end{array}$ & $\begin{array}{c}\text { 10 Emerging } \\
\text { Countries }\end{array}$ \\
\hline & $1880-1913(8)$ & $1973-1998(5)$ \\
\hline $\mathrm{g}_{\text {crisis }}-\mathrm{g}_{(-5)}$ & -0.02 & -0.03 \\
\hline $\mathrm{g}_{\text {crisis }}-\mathrm{g}_{(-3)}$ & -0.02 & -0.03 \\
\hline $\mathrm{g}_{\text {crisis }}-\mathrm{g}_{(-1)}$ & -0.03 & -0.02 \\
\hline $\mathrm{g}_{(+1)}-\mathrm{g}_{\text {crisis }}$ & -0.03 & 0.02 \\
\hline $\mathrm{g}_{(+3)}-\mathrm{g}_{\text {crisis }}$ & 0.00 & 0.02 \\
\hline $\mathrm{g}_{(+5)}-\mathrm{g}_{\text {crisis }}$ & 0.05 & 0.01 \\
\hline
\end{tabular}

Currency Crises: means (number of crises)

\begin{tabular}{|c|c|c|}
\hline & $\begin{array}{c}\text { 15 Emerging } \\
\text { Countries }\end{array}$ & $\begin{array}{c}\text { 10 Emerging } \\
\text { Countries }\end{array}$ \\
\hline & $1880-1913(5)$ & $1973-1998(11)$ \\
\hline $\mathrm{g}_{\text {crisis }}-\mathrm{g}_{(-5)}$ & 0.00 & -0.02 \\
\hline $\mathrm{g}_{\text {crisis }}-\mathrm{g}_{(-3)}$ & 0.03 & -0.01 \\
\hline $\mathrm{g}_{\text {crisis }}-\mathrm{g}_{(-1)}$ & -0.01 & 0.00 \\
\hline $\mathrm{g}_{(+1)}-\mathrm{g}_{\text {crisis }}$ & -0.03 & 0.01 \\
\hline $\mathrm{g}_{(+3)}-\mathrm{g}_{\text {crisis }}$ & 0.02 & 0.00 \\
\hline $\mathrm{g}_{(+5)}-\mathrm{g}_{\text {crisis }}$ & 0.00 & 0.01 \\
\hline
\end{tabular}

Note: $\mathrm{g}_{\text {crisis }}$ is the annual growth rate of real GDP at the crisis year. $\mathrm{g}_{(\mathrm{N})}$ is the average annual growth rate of real GDP N years before (-) or after (+) the crisis.

Data Sources: Bordo and Schwartz (1996a) data base, IFS CD-ROM (1999). 
Table 2. IMF arrangements in millions of SDR's ${ }^{1}$

Latin America

\begin{tabular}{|c|c|c|c|c|c|c|c|c|c|c|c|}
\hline Year & Argentina & Bolivia & Brazil & Chile & Colombia & Ecuador & Mexico & Paraguay & Peru & Uruguay & Venezuela \\
\hline 1973 & & 27.3 & 50.0 & & 40.0 & 16.5 & & & & 20.0 & \\
\hline 1974 & & & & 79.0 & 20.0 & & & & & & \\
\hline 1975 & & & & 79.0 & & & & & & 17.3 & \\
\hline 1976 & 260.0 & & & & & & & & & 25.0 & \\
\hline 1977 & 159.5 & & & & & & 518.0 & & 90.0 & 25.0 & \\
\hline 1978 & & & & & & & & & 184.0 & & \\
\hline 1979 & & & & & & & & & 285.0 & 21.0 & \\
\hline 1980 & & 66.4 & & & & & & & & 21.0 & \\
\hline 1981 & & & & & & & & & & 31.5 & \\
\hline 1982 & & & & & & & & & 650.0 & & \\
\hline 1983 & $1,500.0$ & & & 500.0 & & 157.5 & $3,410.6$ & & & 189.0 & \\
\hline 1984 & 394.2 & & & 166.7 & & & & & 250.0 & 189.0 & \\
\hline 1985 & 394.2 & & & 166.7 & & 105.5 & & & & 122.9 & \\
\hline 1986 & 394.2 & 107.6 & & & & 75.4 & $1,400.0$ & & & & \\
\hline 1987 & 947.5 & & & & & & & & & & \\
\hline 1988 & & 136.1 & 365.3 & & & 109.9 & & & & & \\
\hline 1989 & 736.0 & 163.3 & 365.3 & 64.0 & & & $3,729.6$ & & & & $3,857.1$ \\
\hline 1990 & 736.0 & & 365.3 & & & & & & & 94.8 & \\
\hline 1991 & 780.0 & & 500.0 & & & 75.0 & & & & 94.8 & \\
\hline 1992 & 804.1 & & 500.0 & & & & & & & 50.0 & \\
\hline 1993 & 804.1 & & 500.0 & & & & & & 1018.1 & & \\
\hline 1994 & 804.1 & 101.0 & & & & 173.9 & & & & & \\
\hline 1995 & 804.1 & & & & & & $\begin{array}{c}12,070.2 \\
(26,000.0)\end{array}$ & & & & \\
\hline 1996 & $1,044.1$ & & & & & & & & 300.2 & 100.0 & 975.7 \\
\hline 1997 & 240.0 & & & & & & & & & 41.7 & \\
\hline 1998 & $2,320.0$ & 101.0 & $6,512.4$ & & & & & & & 41.7 & \\
\hline 1999 & & & $6,512.4$ & & & & & & & 41.7 & \\
\hline
\end{tabular}

\footnotetext{
${ }^{1}$ All countries except Argentina, Bolivia, Mexico, Peru, Philippines and Venezuela had only Stand by Arrangements with the IMF over 1973-1999. Programs over multiple years are averaged. Figures in parenthesis indicate loans in U.S. \$ acquired from other sources.
} 
Asia and Other Countries

\begin{tabular}{|c|c|c|c|c|c|c|c|}
\hline Year & Indonesia & Israel & Korea & Philippines & South Africa & Thailand & Turkey \\
\hline 1973 & 50.0 & & 20.0 & 45.0 & & & \\
\hline 1974 & 50.0 & 32.5 & 20.0 & 38.8 & & & \\
\hline 1975 & & 32.5 & 20.0 & 29.1 & & & \\
\hline 1976 & & 29.3 & & 217.0 & 80.0 & & \\
\hline 1977 & & & 20.0 & & 152.0 & & \\
\hline 1978 & & & & & & 45.3 & 300.0 \\
\hline 1979 & & & & 105.0 & & & 250.0 \\
\hline 1980 & & & 640.0 & 410.0 & & & 416.7 \\
\hline 1981 & & & 576.0 & & & 814.5 & 416.7 \\
\hline 1982 & & & & & 364.0 & 271.5 & 416.7 \\
\hline 1983 & & & 575.8 & 315.0 & & & 225.0 \\
\hline 1984 & & & & 615.0 & & & 225.0 \\
\hline 1985 & & & 280.0 & & & 400.0 & \\
\hline 1986 & & & & 198.0 & & & \\
\hline 1987 & & & & & & & \\
\hline 1988 & & & & & & & \\
\hline 1989 & & & & 660.6 & & & \\
\hline 1990 & & & & & & & \\
\hline 1991 & & & & 334.2 & & & \\
\hline 1992 & & & & & & & \\
\hline 1993 & & & & & & & \\
\hline 1994 & & & & 791.2 & & & 203.5 \\
\hline 1995 & & & & & & & 203.5 \\
\hline 1996 & & & & & & & 203.5 \\
\hline 1997 & $\begin{array}{c}8,338.2 \\
(34,000.0)\end{array}$ & & $\begin{array}{c}15,500.0 \\
(42,700.0)\end{array}$ & & & $\begin{array}{c}2,900.0 \\
(14,300.0)\end{array}$ & \\
\hline 1998 & & & & $1,020.8$ & & & \\
\hline 1999 & & & & & & & \\
\hline
\end{tabular}

Source: International Monetary Fund, Annual Reports. 
Table 3. Crises and IMF programs

\section{Latin America}

\begin{tabular}{|c|c|c|c|c|c|c|c|c|c|c|c|}
\hline Year & ARGENTINA & BOLIVIA & BRAZIL & CHILE & COLOMBIA & ECUADOR & MEXICO & PARAGUAY & PERU & URUGUAY & VENEZUELA \\
\hline 1973 & & & & & & & & & & & \\
\hline 1974 & & & & & & & & & & & \\
\hline 1975 & $\mathrm{cc}$ & & & $\mathrm{cc}$ & & & & & $\mathrm{cc}$ & cc & \\
\hline 1976 & & & & $\mathrm{bc}$ & & & $\infty$ & & & & \\
\hline 1977 & & & & $\mathrm{Cc}$ & & & & & cc & & \\
\hline 1978 & & & & & & & & & & & \\
\hline 1979 & & & & & & & & & & $\mathrm{cc}$ & \\
\hline 1980 & $\mathrm{bc}$ & & & & & & & & & & $b c$ \\
\hline 1981 & & & & $b c$ & & $b c$ & $b c$ & & & bc & \\
\hline 1982 & $\mathrm{cc}$ & $\mathrm{cc}$ & & $\mathrm{cc}$ & $b c$ & $\infty$ & $\propto$ & & & $\mathrm{cc}$ & \\
\hline 1983 & & $c c$ & & & & & $\propto$ & & tc & $\mathrm{cc}$ & \\
\hline 1984 & $\mathrm{Cc}$ & & & cc & & $\propto$ & & $\propto$ & & . & $\mathrm{cc}$ \\
\hline 1985 & $b c$ & tc & & & & $\infty$ & $\propto$ & & & & 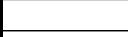 \\
\hline 1986 & & & & & & & & $\propto$ & & $\mathrm{CC}$ & cc \\
\hline 1987 & $\mathrm{cc}$ & & $\mathrm{cc}$ & & & & & & & & 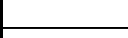 \\
\hline 1988 & & & & & & $\propto$ & & & $c c$ & & \\
\hline 1989 & tc & & & & & & & $\propto$ & & & cc \\
\hline 1990 & & & tc & & & & $\infty$ & & cc & & \\
\hline 1991 & $\mathrm{cc}$ & & & & & $\propto$ & & & & & \\
\hline 1992 & & & & & & & & & $\mathrm{cc}$ & & \\
\hline 1993 & & & & & & & & & & & $b c$ \\
\hline 1994 & & & $b c$ & & & & te & & & & $c c$ \\
\hline 1995 & tc & & & & & & & $b c$ & & & $c c$ \\
\hline 1996 & & & & & & & & & & & \\
\hline 1997 & & & & & & & & & & & \\
\hline 1998 & & & & & & & & & & & \\
\hline 1999 & & & & & & & & & & & \\
\hline
\end{tabular}

Asia and Other Countries

\begin{tabular}{|c|c|c|c|c|c|c|c|c|c|c|c|c|}
\hline Year AUSTRALIA & HONG KONG & INDONESIA & ISRAEL & KOREA & MALAYSIA & NEW ZEALAND & PHILIPPINES & SINGAPORE & SOUTHAFRICA & THAILAND & TURKEY & TAIWAN \\
\hline \begin{tabular}{|l|l}
1973 \\
\end{tabular} & & & & & & & & & & & & \\
\hline 1974 & & & & & & & & & & & & \\
\hline 1975 & & cc & & & cc & cc & & & cc & & 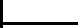 & \\
\hline 1976 cc & & & & & & & & & & & & \\
\hline 1977 & & & tc & & & & & & bc & & cc & \\
\hline 1978 & & $c c$ & & & & $c c$ & & & $c c$ & & & \\
\hline 1979 & & & & & & & & & & & cc & \\
\hline 1980 & & & & $\mathrm{cc}$ & & $\mathrm{cc}$ & & & & & 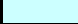 & \\
\hline 1981 & & & & & & & bc & & $c c$ & & 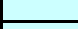 & \\
\hline 1982 & bc & & & & & & $\mathrm{cc}$ & bc & $c c$ & & bc & \\
\hline $1983 \mathrm{cc}$ & $\mathrm{bc}$ & cc & & & & & $\mathrm{cc}$ & & 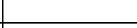 & bc & 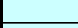 & $b c$ \\
\hline 1984 & & & & & & $\mathrm{cc}$ & 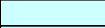 & & cc & & cc & \\
\hline 1985 cc & & & & & bc & & & & $\mathrm{bc}$ & & . & \\
\hline 1986 & & cc & & & & & $c c$ & & $c c$ & 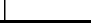 & 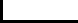 & \\
\hline 1987 & & & & & & bc & & & & & & \\
\hline 1988 & & & & & & $\mathrm{cc}$ & 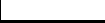 & & $c c$ & & $\mathrm{~L}$ & \\
\hline $1989 \mathrm{bc}$ & & & & & & & & & & & & \\
\hline 1990 & & & & & & & cc & & & & & \\
\hline 1991 & & & & & & & & & & & te & \\
\hline 1992 & & $b c$ & & & & & & & $c c$ & & & \\
\hline 1993 & & & & & & & & & & & & \\
\hline 1994 & & & & & & & & & & & t & \\
\hline 1995 & & & & & & & & & cc & & $c c$ & $\mathrm{bc}$ \\
\hline 1996 & & & & & & & & & & & & \\
\hline 1997 & & tc & & tc & cc & & cc & & & tc & & \\
\hline 1998 & & & & & & & & & & & & \\
\hline 1999 & & & & & & & & & & & & \\
\hline
\end{tabular}

Note: The shaded boxes denote the years spent in an IMF program. CC, BC and TC denote currency, banking and twin crises respectively.

Sources: IMF World Economic Outlook (1998) Chapter IV; See Table 2 above. 


\begin{tabular}{|ll|}
\hline Target variables $\left(\mathbf{y}^{\mathbf{i}}\right)$ & \\
Growth rate of real GDP & GDPGR \\
Current Account/GDP & CA \\
Inflation & INF \\
Balance of payments & BOP \\
Policy variables $\left(\mathbf{X}^{\mathbf{i}}\right)$ & \\
Domestic credit creation & \\
Budget Deficit & MGR \\
Real exchange rate & GB \\
Exogenous variables $\left(\mathbf{W}^{\mathbf{i}}\right)$ & REX \\
World rate of interest & \\
Participation variables $\left(\omega^{\mathbf{i}}\right)$ & USINT \\
IMF participation & \\
Lagged values of participation & IMF \\
Foreign exchange reserves/Imports & IMFLAG\# \\
Growth rate of real GDP (GDPGR) & FOREX \\
Liabilities of the banking system & GDPGR \\
Growth rate of Real domestic credit & LIAB \\
Proportion of Short-term Debt & CGR \\
Devaluation of real Exchange rate & STDEBT \\
Dummy for Latin American countries & DEVAL \\
Dummy for Asian Tigers & LAMD \\
Other variables & ATD \\
Dummy for Regime change of IMF & IMFR \\
Lagged Dummy for Regime change of IMF & IMFR\# \\
IMF selectivity variable & IMFS \\
\hline
\end{tabular}

\footnotetext{
${ }^{2}$ Growth rate of the $M_{1}$ money supply

${ }^{3}$ Liabilities of banking system is derived by adding Money and Quasi-Money converted into U.S.\$ and normalized by Total Reserves minus Gold.
} 
Table 5. Probit Results from 1973-1998 Annual Data

\begin{tabular}{|cccc|}
\hline Variable & Coefficient & T-Statistic & P-value \\
\hline C & & & \\
LAMD & -1.103277 & -6.40 & 0.00 \\
ATD & -0.439335 & 2.14 & 0.03 \\
IMFLAG1 & 1.278713 & -1.70 & 0.09 \\
IMFLAG2 & 0.304632 & 1.62 & 0.00 \\
IMFLAG3 & 0.277094 & 1.57 & 0.11 \\
GDPGR & -0.024515 & -1.51 & 0.13 \\
FOREX & -0.031942 & -1.17 & 0.24 \\
DEVAL & 0.005755 & 1.70 & 0.09 \\
LIAB & $5.21 \mathrm{E}-07$ & 1.50 & 0.14 \\
CGRLAG & 0.000833 & 0.65 & 0.52 \\
& & & \\
Log likelihood & -192.07 & & \\
Obs with Dep=1 & 122.00 & & \\
Obs with Dep=0 & 367.00 & & \\
\hline
\end{tabular}


Table 6. The Impact of IMF programs on target variables: Annual Data 1973-1998

\begin{tabular}{|c|c|c|c|c|}
\hline Variable & Coefficient & T-Statistic & P-value & R-squared \\
\hline $\begin{array}{l}\text { GDPGRLAG } \\
\text { CALAG } \\
\text { INFLAG } \\
\text { GBLAG } \\
\text { MGRLAG } \\
\text { REXLAG } \\
\text { USINT } \\
\text { IMF } \\
\text { IMFLAG1 } \\
\text { IMFS }\end{array}$ & $\begin{array}{c}\text { A. Real GDP } \\
0.212726 \\
0.169962 \\
0.000223 \\
0.010509 \\
-0.000289 \\
2.118708 \\
-0.084653 \\
-1.618278 \\
2.235222 \\
1.060301\end{array}$ & $\begin{array}{c}\text { growth } \\
3.01 \\
3.20 \\
0.79 \\
0.18 \\
-0.70 \\
1.04 \\
-1.15 \\
-0.97 \\
2.67 \\
0.83\end{array}$ & $\begin{array}{l}0.00 \\
0.00 \\
0.43 \\
0.86 \\
0.48 \\
0.30 \\
0.25 \\
0.33 \\
0.01 \\
0.40\end{array}$ & 0.3 \\
\hline $\begin{array}{l}\text { GDPGRLAG } \\
\text { CALAG } \\
\text { INFLAG } \\
\text { GBLAG } \\
\text { MGRLAG } \\
\text { REXLAG } \\
\text { USINT } \\
\text { IMF } \\
\text { IMFLAG1 } \\
\text { IMFS }\end{array}$ & $\begin{array}{c}\text { B. Current Ac } \\
-0.164952 \\
0.571764 \\
-0.0003 \\
0.002489 \\
0.000171 \\
-0.361288 \\
-0.15652 \\
1.296802 \\
-0.384036 \\
-0.21955\end{array}$ & $\begin{array}{c}\text { count } \\
-3.03 \\
10.35 \\
-2.51 \\
0.05 \\
0.66 \\
-0.32 \\
-2.36 \\
1.35 \\
-0.65 \\
-0.27\end{array}$ & $\begin{array}{l}0.00 \\
0.00 \\
0.01 \\
0.96 \\
0.51 \\
0.75 \\
0.02 \\
0.18 \\
0.52 \\
0.78\end{array}$ & 0.55 \\
\hline $\begin{array}{l}\text { GDPGRLAG } \\
\text { BOPLAG } \\
\text { BOPLAG } \\
\text { GBLAG } \\
\text { MGRLAG } \\
\text { REXLAG } \\
\text { USINT } \\
\text { IMF } \\
\text { IMFLAG1 } \\
\text { IMFS }\end{array}$ & $\begin{array}{c}\text { C. Balance o } \\
0.00659 \\
0.237046 \\
-0.0000261 \\
0.067144 \\
0.000318 \\
-0.947169 \\
-0.100736 \\
0.709718 \\
0.317362 \\
0.318621\end{array}$ & $\begin{array}{c}\text { Payments } \\
0.21 \\
2.12 \\
-0.37 \\
2.17 \\
2.23 \\
-1.15 \\
-2.74 \\
1.48 \\
0.98 \\
0.77\end{array}$ & $\begin{array}{l}0.83 \\
0.03 \\
0.71 \\
0.03 \\
0.03 \\
0.25 \\
0.01 \\
0.14 \\
0.33 \\
0.44\end{array}$ & 0.42 \\
\hline $\begin{array}{l}\text { GDPGRLAG } \\
\text { CALAG } \\
\text { INFLAG } \\
\text { GBLAG } \\
\text { MGRLAG } \\
\text { REXLAG } \\
\text { USINT } \\
\text { IMF } \\
\text { IMFLAG1 } \\
\text { IMFS }\end{array}$ & $\begin{array}{c}\text { D. Inflation } \\
-7.04287 \\
1.537034 \\
-0.235921 \\
-6.793855 \\
1.348687 \\
182.7192 \\
-1.080968 \\
124.9477 \\
-95.03139 \\
-58.4982 \\
\end{array}$ & $\begin{array}{c}-0.97 \\
0.20 \\
-1.41 \\
-0.19 \\
2.68 \\
0.38 \\
-0.09 \\
0.54 \\
-0.84 \\
-0.54 \\
\end{array}$ & $\begin{array}{l}0.33 \\
0.84 \\
0.16 \\
0.85 \\
0.01 \\
0.70 \\
0.93 \\
0.59 \\
0.40 \\
0.59 \\
\end{array}$ & 0.52 \\
\hline
\end{tabular}


Table 7. Probit Results from Quarterly Data

\begin{tabular}{|c|c|c|c|}
\hline \multicolumn{4}{|c|}{ (i) 1973Q1-1998Q4 } \\
\hline Variable & Coefficient & T-Statistic & P-value \\
\hline C & -1.279346 & -15.11 & 0.00 \\
\hline ATD & -0.205369 & -1.61 & 0.11 \\
\hline LAMD & 0.467341 & 4.74 & 0.00 \\
\hline FOREX & -0.049956 & -3.59 & 0.00 \\
\hline GDP & -0.013477 & -2.86 & 0.00 \\
\hline GDPL1 & -0.013815 & -2.98 & 0.00 \\
\hline GDPL2 & -0.018508 & -4.04 & 0.00 \\
\hline GDPL3 & -0.0159 & -3.48 & 0.00 \\
\hline LIAB & $-1.17 \mathrm{E}-07$ & -0.64 & 0.52 \\
\hline LIABLAG1 & 2.23E-09 & 0.03 & 0.98 \\
\hline CGRLAG1 & 0.004439 & 1.71 & 0.09 \\
\hline CGRLAG2 & 0.004854 & 1.85 & 0.06 \\
\hline CGRLAG3 & 0.004218 & 1.60 & 0.11 \\
\hline IMFLAG4 & 1.338432 & 15.09 & 0.00 \\
\hline IMFLAG8 & 0.382985 & 4.24 & 0.00 \\
\hline \multicolumn{4}{|c|}{-700.01} \\
\hline \multicolumn{4}{|c|}{ (ii) 1986Q1-1998Q4 } \\
\hline Variable & Coefficient & T-Statistic & P-value \\
\hline C & -1.708568 & -7.90 & 0.00 \\
\hline ATD & -0.465355 & -2.16 & 0.03 \\
\hline LAMD & 0.650043 & 4.36 & 0.00 \\
\hline FOREX & -0.036776 & -1.63 & 0.10 \\
\hline GDP & -0.017336 & -2.17 & 0.03 \\
\hline GDPL1 & -0.016672 & -2.11 & 0.04 \\
\hline GDPL2 & -0.025663 & -3.24 & 0.00 \\
\hline GDPL3 & -0.022036 & -2.76 & 0.01 \\
\hline LIAB & -0.000472 & -1.64 & 0.10 \\
\hline LIABLAG1 & 0.000401 & 1.64 & 0.10 \\
\hline CGRLAG1 & 0.02734 & 3.86 & 0.00 \\
\hline CGRLAG2 & 0.020818 & 2.81 & 0.01 \\
\hline CGRLAG3 & 0.018877 & 2.79 & 0.01 \\
\hline IMFLAG5 & 1.161391 & 8.52 & 0.00 \\
\hline IMFLAG8 & 0.414807 & 2.99 & 0.00 \\
\hline STDEBT & 0.521393 & 1.86 & 0.06 \\
\hline Log likelihood & -333.3715 & & \\
\hline
\end{tabular}


Table 8. The Impact of IMF programs on target variables: Quarterly Data

\begin{tabular}{|c|c|c|c|c|c|c|c|c|c|}
\hline & (i) $1973 \mathrm{C}$ & $-1998 Q 4$ & & & & (ii) $1973 Q$ & $-1998 Q 4$ & & \\
\hline A. Real GDP g & owth & & & & A. Real GDP & owth & & & \\
\hline Variable & Coefficient & T-Statistic & P-value & R-squared & Variable & Coefficient & T-Statistic & $P$-value & R-squared \\
\hline GDPGRLAG1 & -0.194837 & -4.11 & 0.00 & 0.09 & GDPGRLAG1 & -0.228137 & -3.98 & 0.00 & 0.09 \\
\hline CALAG & -4.70482 & -1.89 & 0.06 & & CALAG & -0.916707 & -0.30 & 0.76 & \\
\hline GBLAG & 9.429126 & 3.12 & 0.00 & & GBLAG & 9.961817 & 1.89 & 0.06 & \\
\hline MGRLAG & 5.08E-05 & 0.06 & 0.95 & & MGRLAG & $-8.28 \mathrm{E}-05$ & -0.11 & 0.92 & \\
\hline REXLAG & 4.416839 & 1.62 & 0.11 & & REXLAG & -1.952696 & -1.87 & 0.06 & \\
\hline USINT & -0.007382 & -0.11 & 0.91 & & USINT & -0.090739 & -0.49 & 0.62 & \\
\hline IMF & -4.429141 & -2.53 & 0.01 & & IMF & -1.455428 & -0.79 & 0.43 & \\
\hline IMFLAG1 & 1.276899 & 0.91 & 0.36 & & IMFLAG1 & 0.395372 & 0.23 & 0.82 & \\
\hline IMFLAG2 & -2.24678 & -1.41 & 0.16 & & IMFLAG2 & -0.979249 & -0.69 & 0.49 & \\
\hline IMFLAG3 & 1.228918 & 0.71 & 0.48 & & IMFLAG3 & 3.299798 & 1.70 & 0.09 & \\
\hline IMFLAG4 & 1.602258 & 1.01 & 0.31 & & IMFLAG4 & -2.183276 & -1.38 & 0.17 & \\
\hline IMFR & -3.417592 & -1.72 & 0.09 & & IMFR & -2.82439 & -1.39 & 0.17 & \\
\hline IMFR1 & 0.038629 & 0.01 & 0.99 & & IMFR1 & -0.220757 & -0.07 & 0.94 & \\
\hline IMFR2 & 0.558068 & 0.18 & 0.86 & & IMFR2 & -0.271346 & -0.09 & 0.93 & \\
\hline IMFR3 & 5.940452 & 2.04 & 0.04 & & IMFR3 & 5.261027 & 1.68 & 0.09 & \\
\hline IMFR4 & -3.002939 & -1.42 & 0.16 & & IMFR4 & -1.204628 & -0.53 & 0.60 & \\
\hline IMFS & 2.723532 & 2.00 & 0.05 & & IMFS & 0.737219 & 0.62 & 0.54 & \\
\hline B. Current Acc & & & & & B. Current Acc & unt & & & \\
\hline Variable & Coefficient & T-Statistic & P-value & R-squared & Variable & Coefficient & T-Statistic & P-value & R-squared \\
\hline GDPGRLAG1 & -0.000096 & -0.95 & 0.34 & 0.75 & GDPGRLAG1 & -0.000136 & -1.14 & 0.25 & 0.84 \\
\hline BOPLAG & -0.054051 & -1.84 & 0.07 & & BOPLAG & -0.067493 & -2.64 & 0.01 & \\
\hline CALAG & 0.768435 & 21.68 & 0.00 & & CALAG & 0.890428 & 32.45 & 0.00 & \\
\hline GBLAG & 6.10E-02 & 2.14 & 0.03 & & GBLAG & 0.047522 & 1.35 & 0.18 & \\
\hline MGRLAG & 1.66E-06 & 0.99 & 0.32 & & MGRLAG & 1.27E-06 & 0.80 & 0.42 & \\
\hline REXLAG & -0.011559 & -2.29 & 0.02 & & REXLAG & 0.008587 & 2.77 & 0.01 & \\
\hline USINT & -0.000922 & -2.80 & 0.01 & & USINT & -0.000185 & -0.28 & 0.78 & \\
\hline IMF & -0.009108 & -1.74 & 0.08 & & IMF & -0.011985 & -2.02 & 0.04 & \\
\hline IMFLAG1 & -0.001948 & -0.47 & 0.64 & & IMFLAG1 & 0.006508 & 1.11 & 0.27 & \\
\hline IMFLAG2 & 0.006554 & 1.25 & 0.21 & & IMFLAG2 & 0.001452 & 0.23 & 0.82 & \\
\hline IMFLAG3 & -0.012823 & -1.93 & 0.05 & & IMFLAG3 & -0.013987 & -1.43 & 0.15 & \\
\hline IMFLAG4 & 0.009588 & 1.77 & 0.08 & & IMFLAG4 & 0.008013 & 1.03 & 0.30 & \\
\hline IMFR & 0.021665 & 3.15 & 0.00 & & IMFR & 0.020699 & 3.22 & 0.00 & \\
\hline IMFR1 & -0.007889 & -0.87 & 0.38 & & IMFR1 & -0.015433 & -1.62 & 0.11 & \\
\hline IMFR2 & -0.014706 & -1.45 & 0.15 & & IMFR2 & -0.010979 & -1.02 & 0.31 & \\
\hline IMFR3 & -0.006865 & -0.55 & 0.58 & & IMFR3 & -0.00784 & -0.50 & 0.61 & \\
\hline IMFR4 & 0.003416 & 0.30 & 0.76 & & IMFR4 & 0.010997 & 0.74 & 0.46 & \\
\hline IMFS & 0.012016 & 2.91 & 0.00 & & IMFS & 0.011356 & 2.59 & 0.01 & \\
\hline
\end{tabular}




\begin{tabular}{|c|c|c|c|c|c|c|c|c|c|}
\hline \multicolumn{5}{|c|}{ 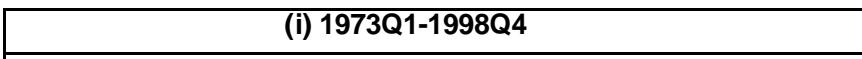 } & \multicolumn{5}{|c|}{ (ii) 1973Q1-1998Q4 } \\
\hline \multicolumn{5}{|c|}{ C. Balance of Payments } & \multicolumn{5}{|c|}{ C. Balance of Payments } \\
\hline Variable & Coefficient & T-Statistic & P-value & R-squared & Variable & Coefficient & T-Statistic & P-value & R-squared \\
\hline GDPGRLAG1 & 0.0000467 & 0.40 & 0.69 & 0.17 & GDPGRLAG1 & -0.0000642 & -0.37 & 0.71 & 0.14 \\
\hline BOPLAG & 0.130835 & 2.47 & 0.01 & & BOPLAG & 0.284684 & 3.76 & 0.00 & \\
\hline CALAG & 0.074574 & 2.07 & 0.04 & & CALAG & 0.052823 & 1.54 & 0.12 & \\
\hline GBLAG & 6.56E-02 & 1.51 & 0.13 & & GBLAG & 0.113891 & 1.57 & 0.12 & \\
\hline MGRLAG & $1.54 \mathrm{E}-06$ & 0.59 & 0.56 & & MGRLAG & 5.70E-07 & 0.20 & 0.84 & \\
\hline REXLAG & -0.01422 & -1.93 & 0.05 & & REXLAG & 0.007188 & 1.31 & 0.19 & \\
\hline USINT & -0.001218 & -3.03 & 0.00 & & USINT & -0.000269 & -0.22 & 0.83 & \\
\hline IMF & 0.000151 & 0.02 & 0.98 & & IMF & -0.002024 & -0.23 & 0.82 & \\
\hline IMFLAG1 & 0.003137 & 0.57 & 0.57 & & IMFLAG1 & -0.002631 & -0.30 & 0.77 & \\
\hline IMFLAG2 & 0.000604 & 0.11 & 0.91 & & IMFLAG2 & 0.008229 & 0.95 & 0.34 & \\
\hline IMFLAG3 & -0.006655 & -1.06 & 0.29 & & IMFLAG3 & -0.00653 & -0.84 & 0.40 & \\
\hline IMFLAG4 & 0.007582 & 1.13 & 0.26 & & IMFLAG4 & 0.00289 & 0.48 & 0.63 & \\
\hline IMFR & -0.001161 & -0.09 & 0.93 & & IMFR & -0.011279 & -0.97 & 0.33 & \\
\hline IMFR1 & -0.006561 & -0.44 & 0.66 & & IMFR1 & -0.000727 & -0.05 & 0.96 & \\
\hline IMFR2 & 0.009284 & 0.61 & 0.54 & & IMFR2 & 0.004938 & 0.29 & 0.77 & \\
\hline IMFR3 & 0.004538 & 0.32 & 0.75 & & IMFR3 & 0.009935 & 0.60 & 0.55 & \\
\hline IMFR4 & -0.000667 & -0.07 & 0.95 & & IMFR4 & -0.003431 & -0.31 & 0.76 & \\
\hline IMFS & 0.003931 & 0.71 & 0.48 & & IMFS & 0.004984 & 0.77 & 0.44 & \\
\hline \multicolumn{5}{|l|}{ D. Inflation } & \multicolumn{5}{|l|}{ D. Inflation } \\
\hline Variable & Coefficient & T-Statistic & P-value & R-squared & Variable & Coefficient & T-Statistic & P-value & R-squared \\
\hline GDPGRLAG1 & 0.001605 & 0.01 & 0.99 & 0.23 & GDPGRLAG1 & 0.005108 & 0.03 & 0.98 & 0.16 \\
\hline CALAG & 11.94513 & 2.20 & 0.03 & & CALAG & 7.1365 & 2.00 & 0.05 & \\
\hline GBLAG & -46.74658 & -2.87 & 0.00 & & GBLAG & -82.93967 & -2.26 & 0.02 & \\
\hline MGRLAG & 1.91E-02 & 1.66 & 0.10 & & MGRLAG & 2.25E-02 & 1.83 & 0.07 & \\
\hline REXLAG & -14.63897 & -2.05 & 0.04 & & REXLAG & 2.395223 & 0.65 & 0.52 & \\
\hline USINT & 0.24682 & 3.44 & 0.00 & & USINT & 1.861736 & 2.83 & 0.00 & \\
\hline IMF & -3.268191 & -2.14 & 0.03 & & IMF & -7.033035 & -2.70 & 0.01 & \\
\hline IMFLAG1 & -0.814956 & -0.52 & 0.60 & & IMFLAG1 & 0.724205 & 0.47 & 0.64 & \\
\hline IMFLAG2 & -0.313838 & -0.20 & 0.84 & & IMFLAG2 & -1.178112 & -0.77 & 0.44 & \\
\hline IMFLAG3 & -0.15721 & -0.13 & 0.89 & & IMFLAG3 & -1.437471 & -0.98 & 0.33 & \\
\hline IMFLAG4 & -1.20398 & -0.70 & 0.48 & & IMFLAG4 & 0.368653 & 0.26 & 0.79 & \\
\hline IMFR & 2.031731 & 0.94 & 0.35 & & IMFR & 0.633625 & 0.36 & 0.72 & \\
\hline IMFR1 & 0.932841 & 0.33 & 0.74 & & IMFR1 & -1.408366 & -0.59 & 0.55 & \\
\hline IMFR2 & -2.361055 & -0.72 & 0.47 & & IMFR2 & -0.698986 & -0.31 & 0.76 & \\
\hline IMFR3 & -1.851054 & -0.62 & 0.54 & & IMFR3 & 0.646799 & 0.30 & 0.76 & \\
\hline IMFR4 & -4.314645 & -2.08 & 0.04 & & IMFR4 & -2.137043 & -1.24 & 0.21 & \\
\hline IMFS & 0.337269 & 0.26 & 0.80 & & IMFS & 4.813905 & 3.35 & 0.00 & \\
\hline
\end{tabular}


Figure 1. Growth Rates of Real GDP Surrounding Crisis Dates: Annual Data:

Selected Emerging Countries: 1880-1913; 1919-1939; 1973-1999

Currency crisis $=\Delta$ Banking crisis $=\square$ Banking and Currency Crisis $=$ $\mathrm{BC} / \mathrm{CC}$

\section{$1880-1913$}

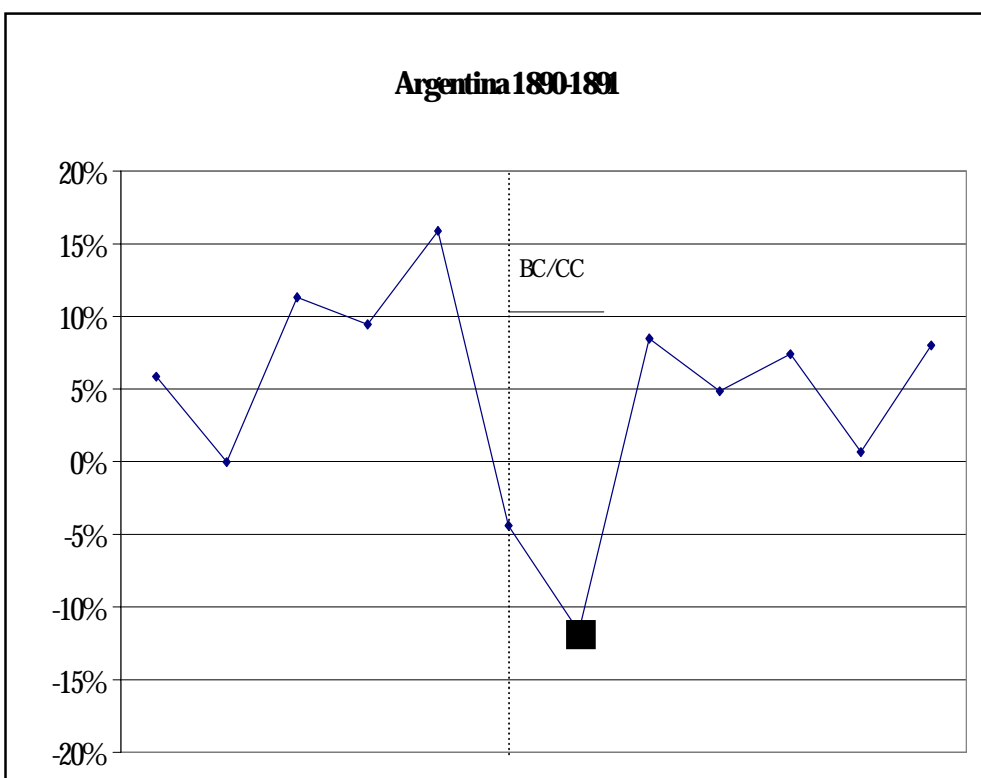

$\begin{array}{llllllllllll}1885 & 1886 & 1887 & 1888 & 1889 & 1890 & 1891 & 1892 & 1893 & 1894 & 1895 & 1896\end{array}$

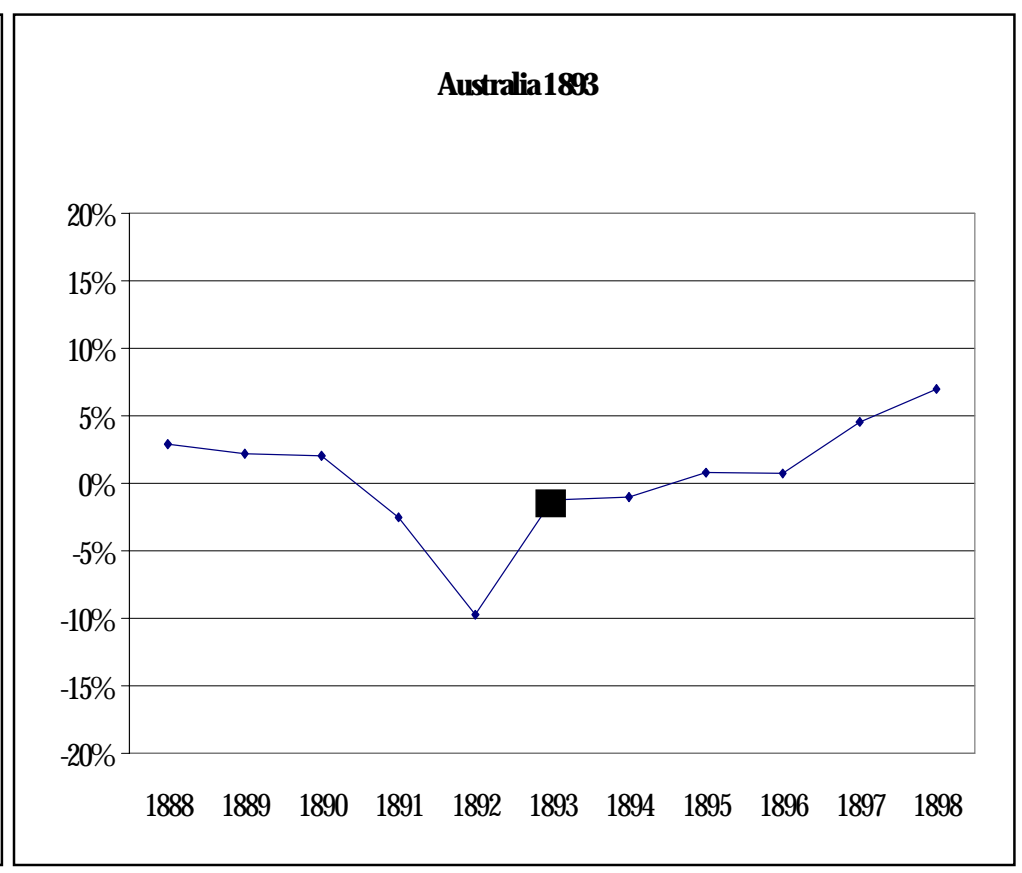

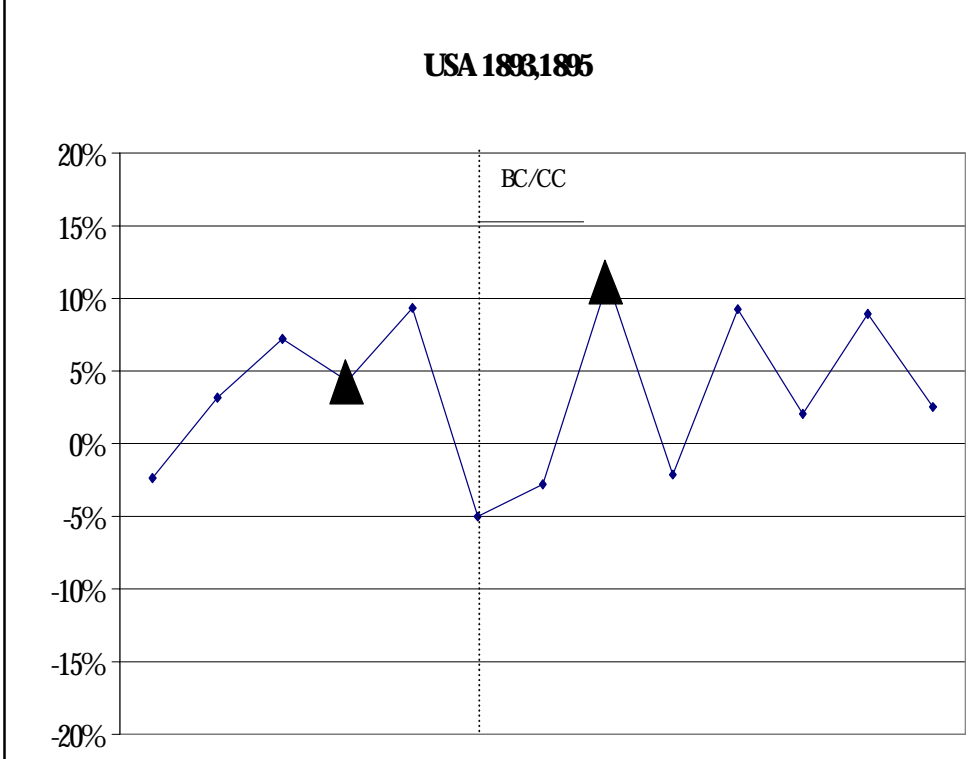

1880188918901891189218931894189518961897189818991900

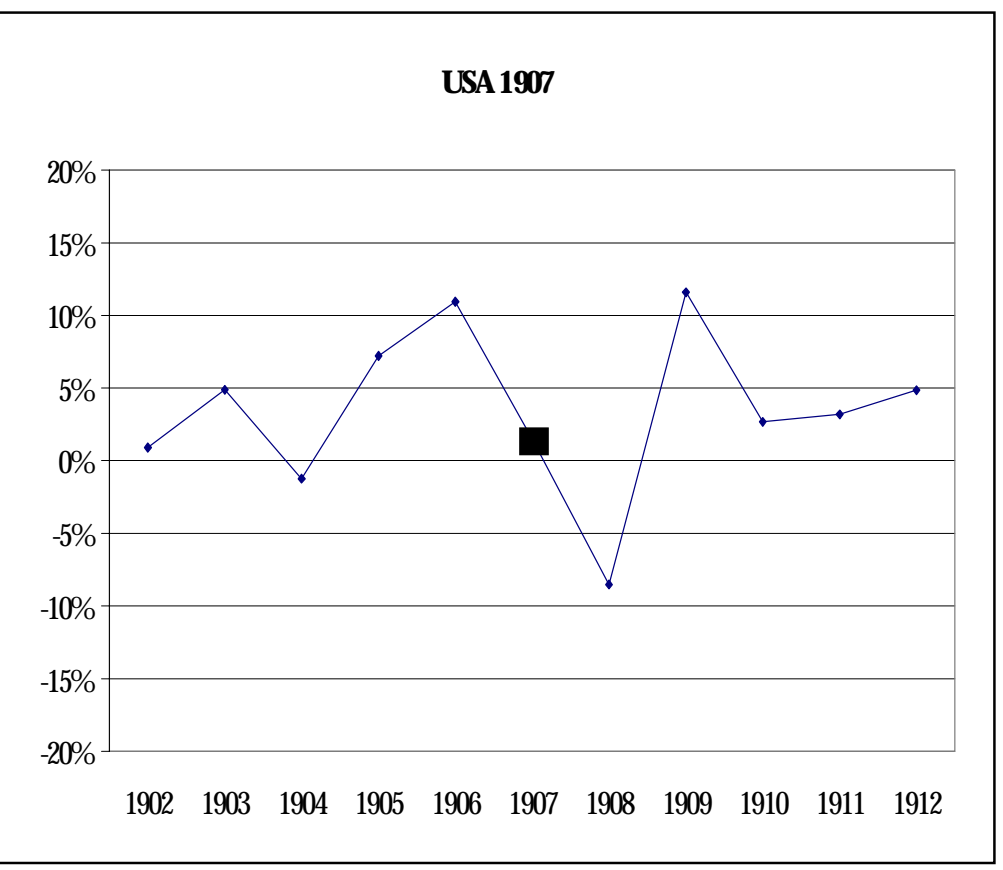


Figure 1 Continued

\section{9-1939}
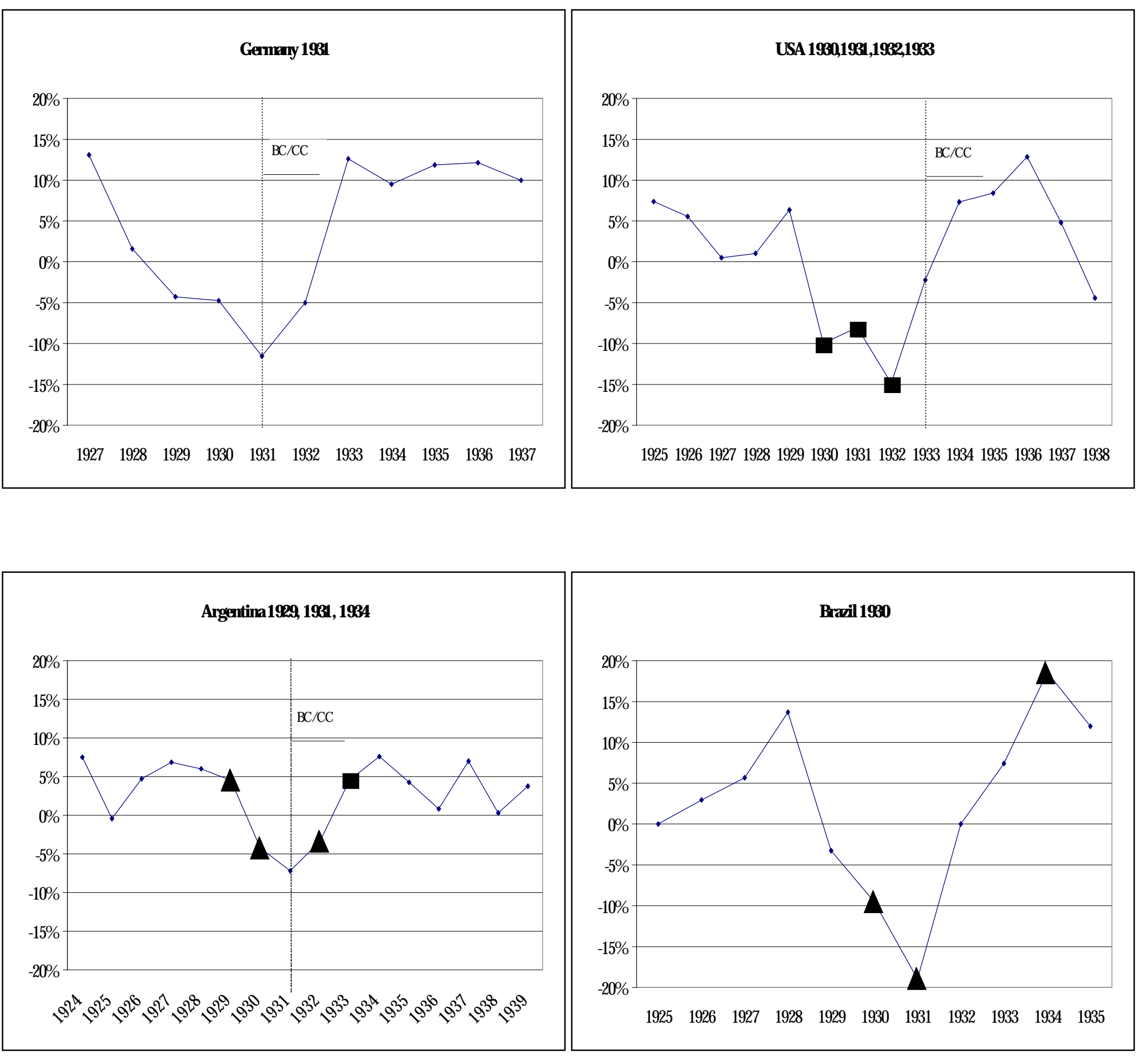
Figure 1 Continued

1973-1999

Indonesia 1992, 1994, 1997-1998

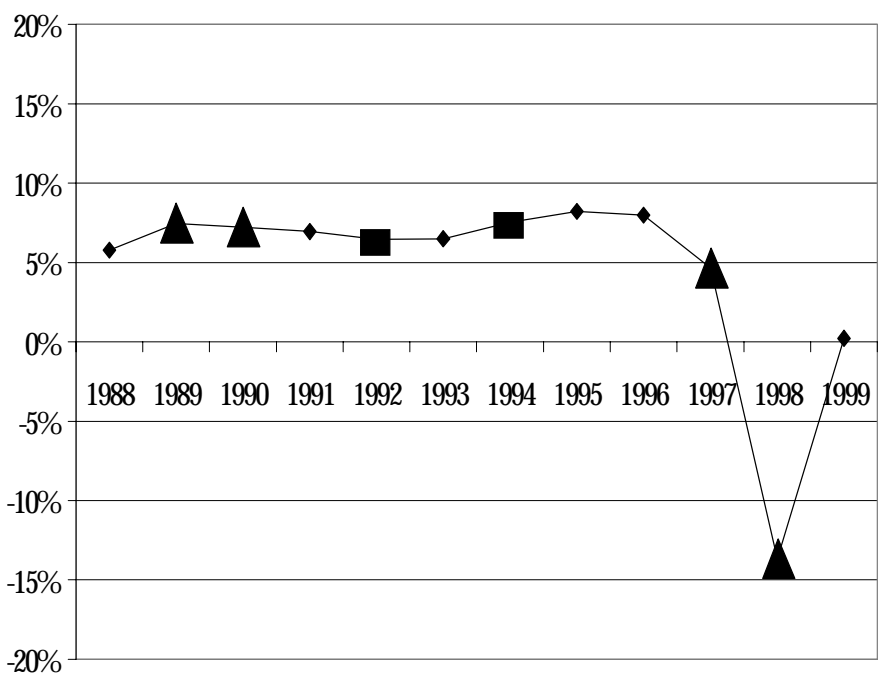

Korea 1997-1998

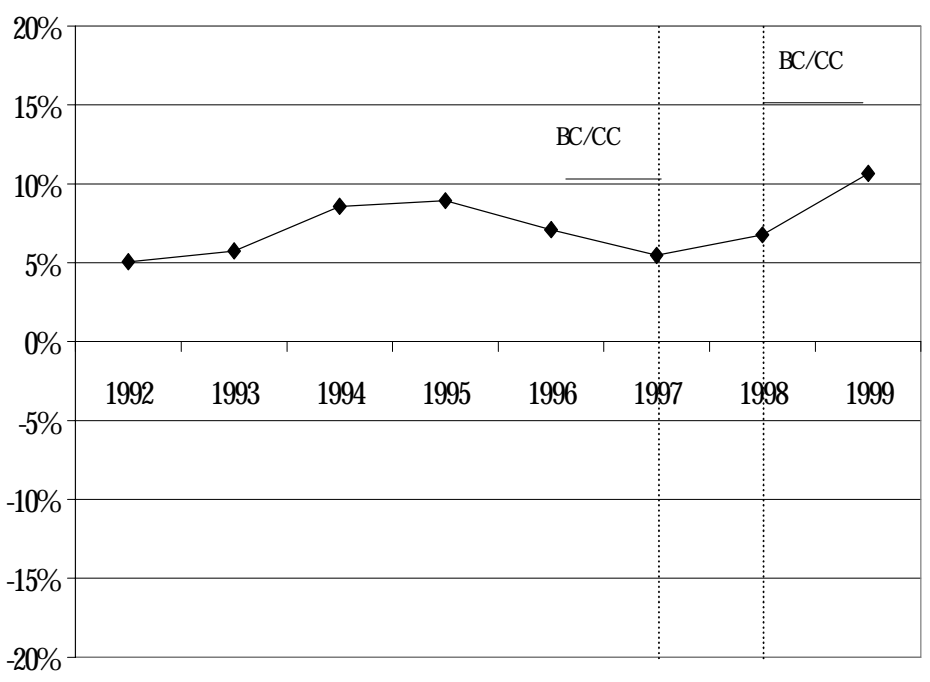

Mexico 1990, 1992, 19941995

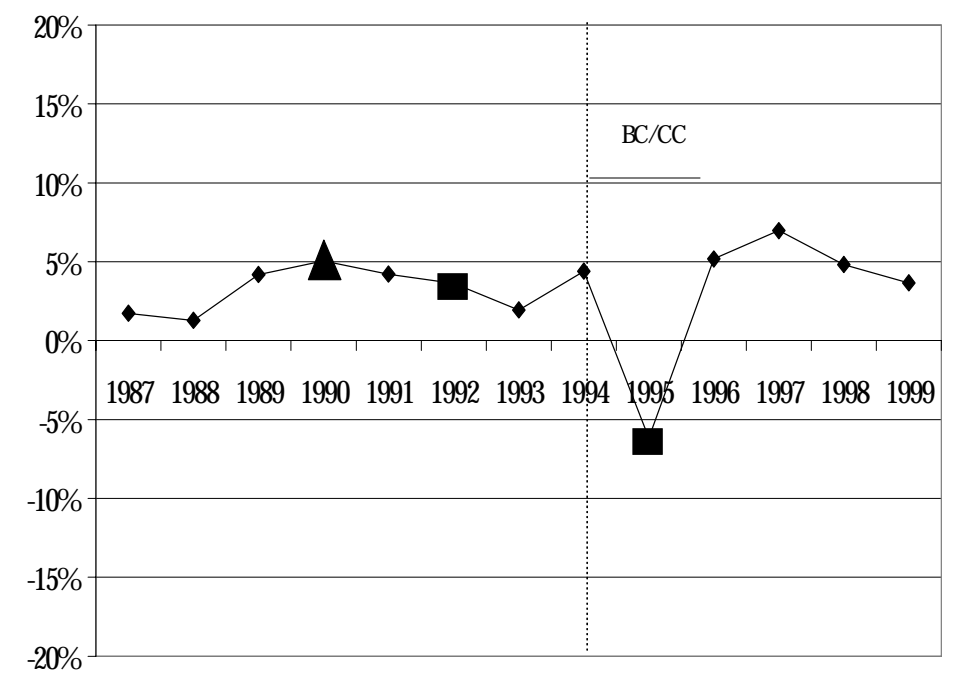

Thailand 1997-1998

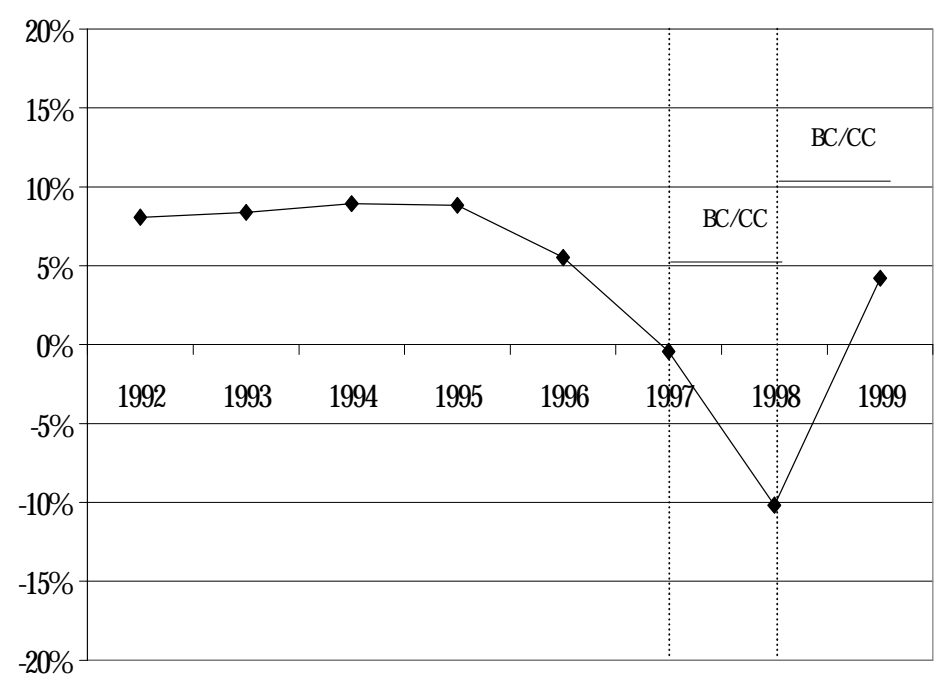

Sources: Bordo and Schwartz (1996a), International Financial Statistics, IMF World Economic Outlook 


\section{Figure 2. Real GDP Growth Rate}
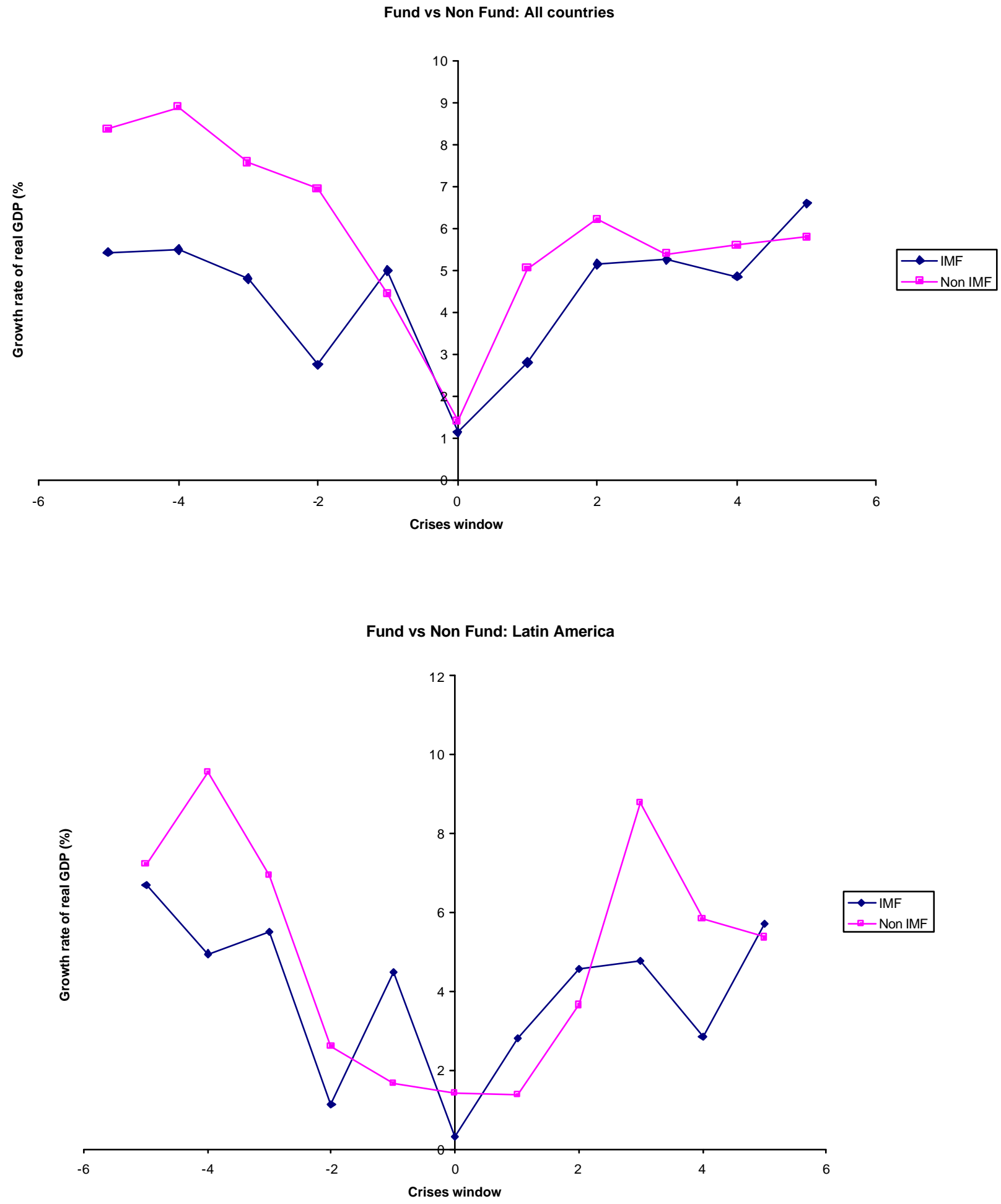


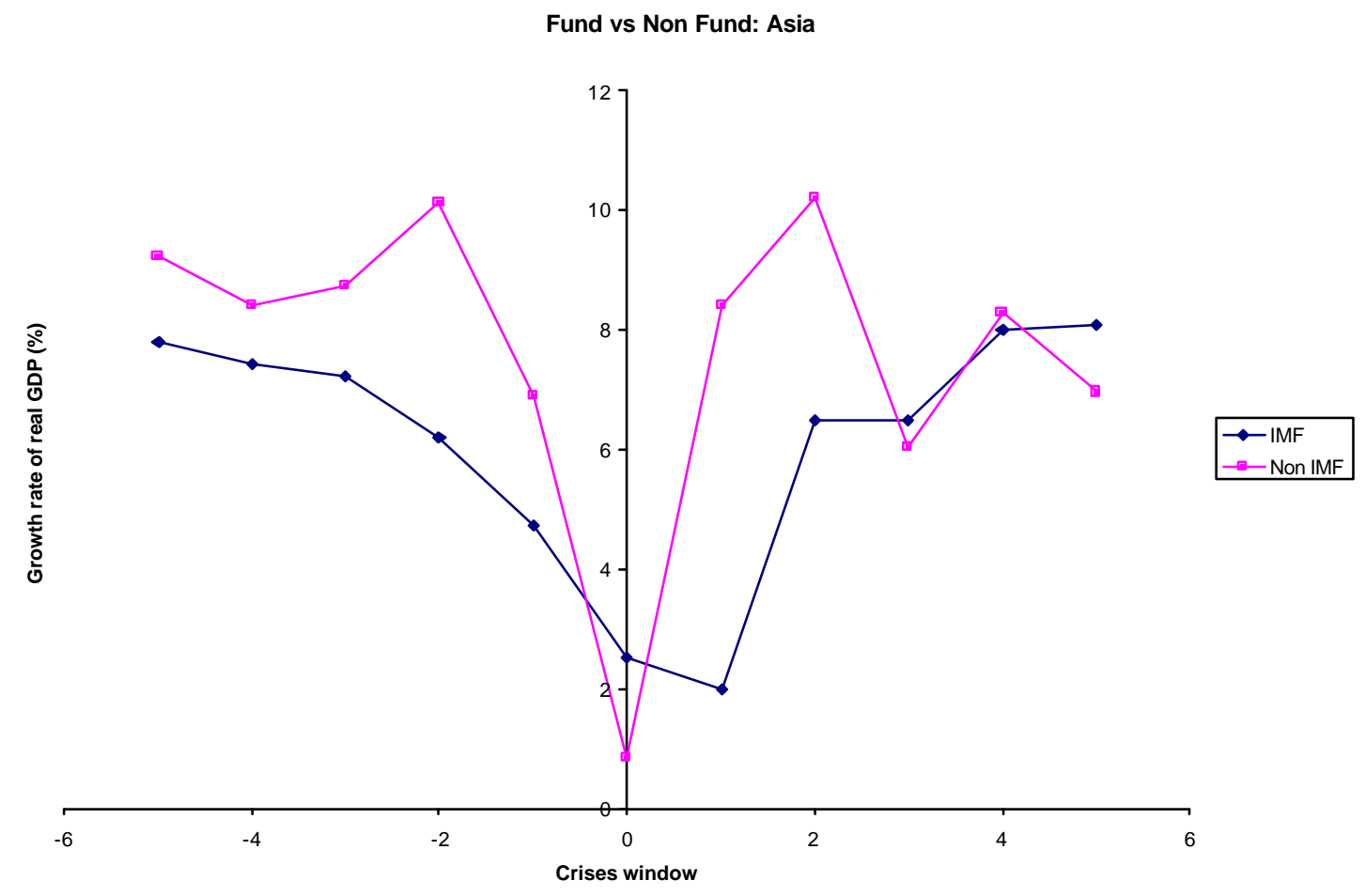

Figure 3. Per Capita Real GDP (in logs)

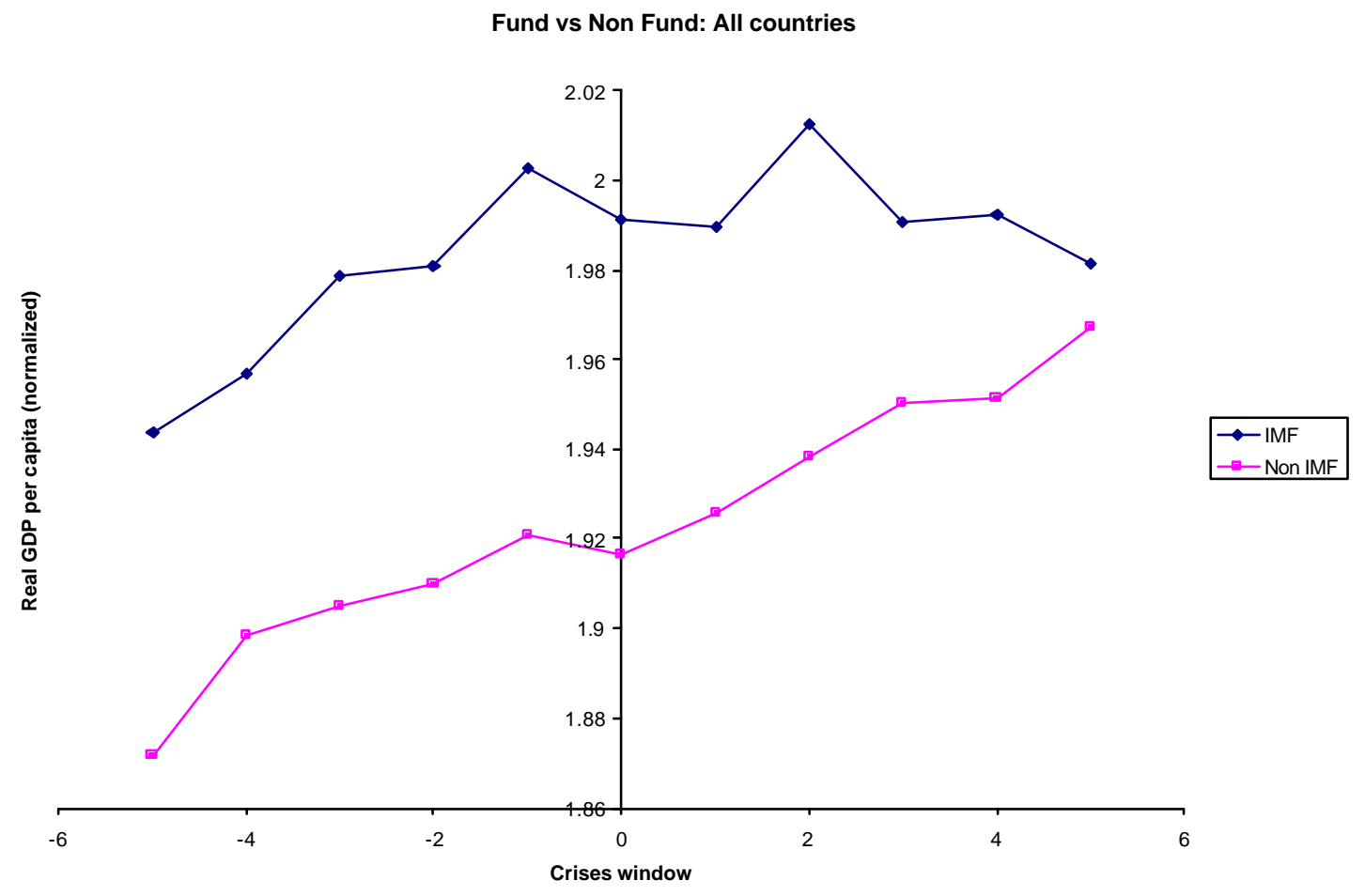


Fund vs Non Fund: Latin America

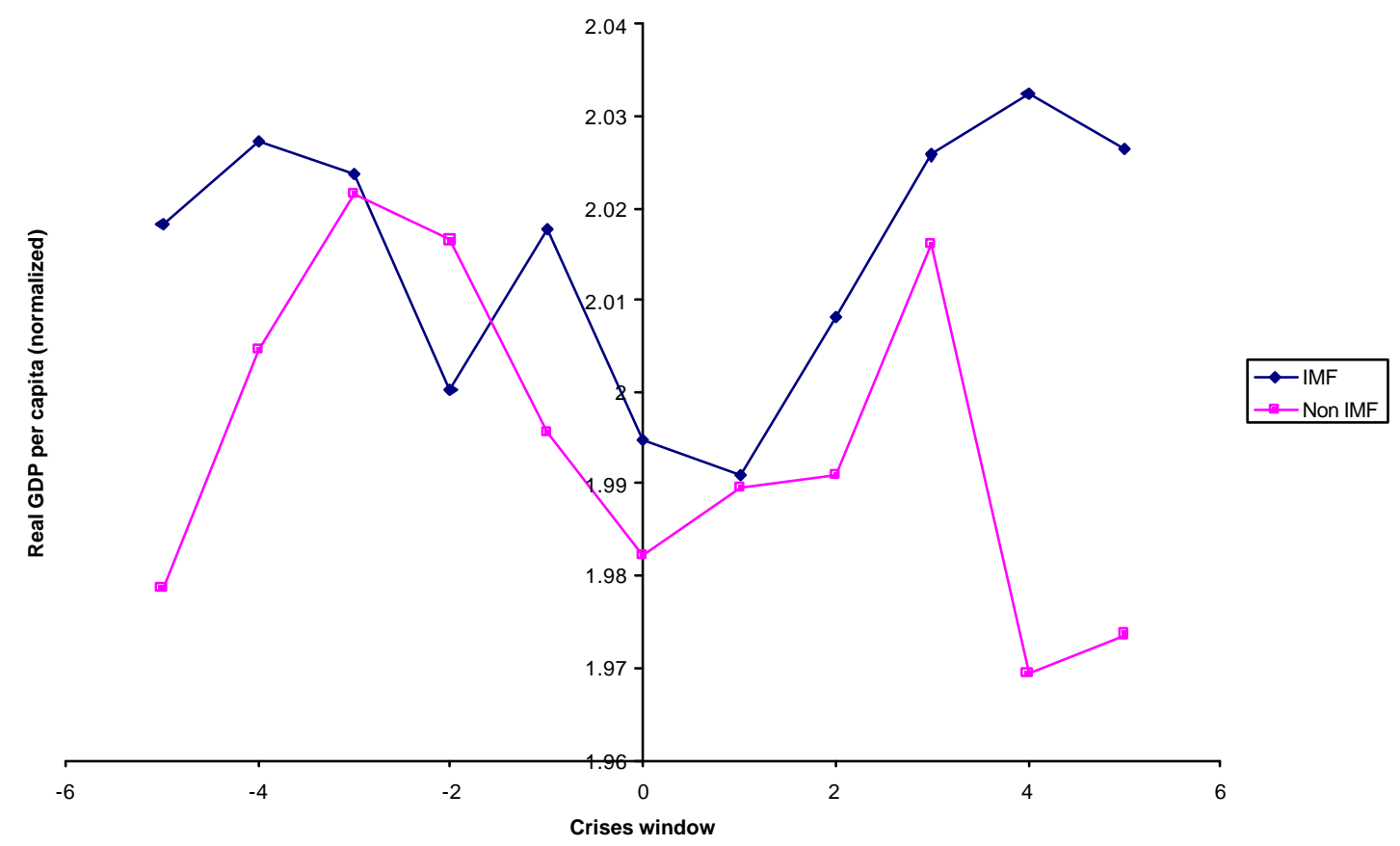

Fund vs Non Fund: Asia

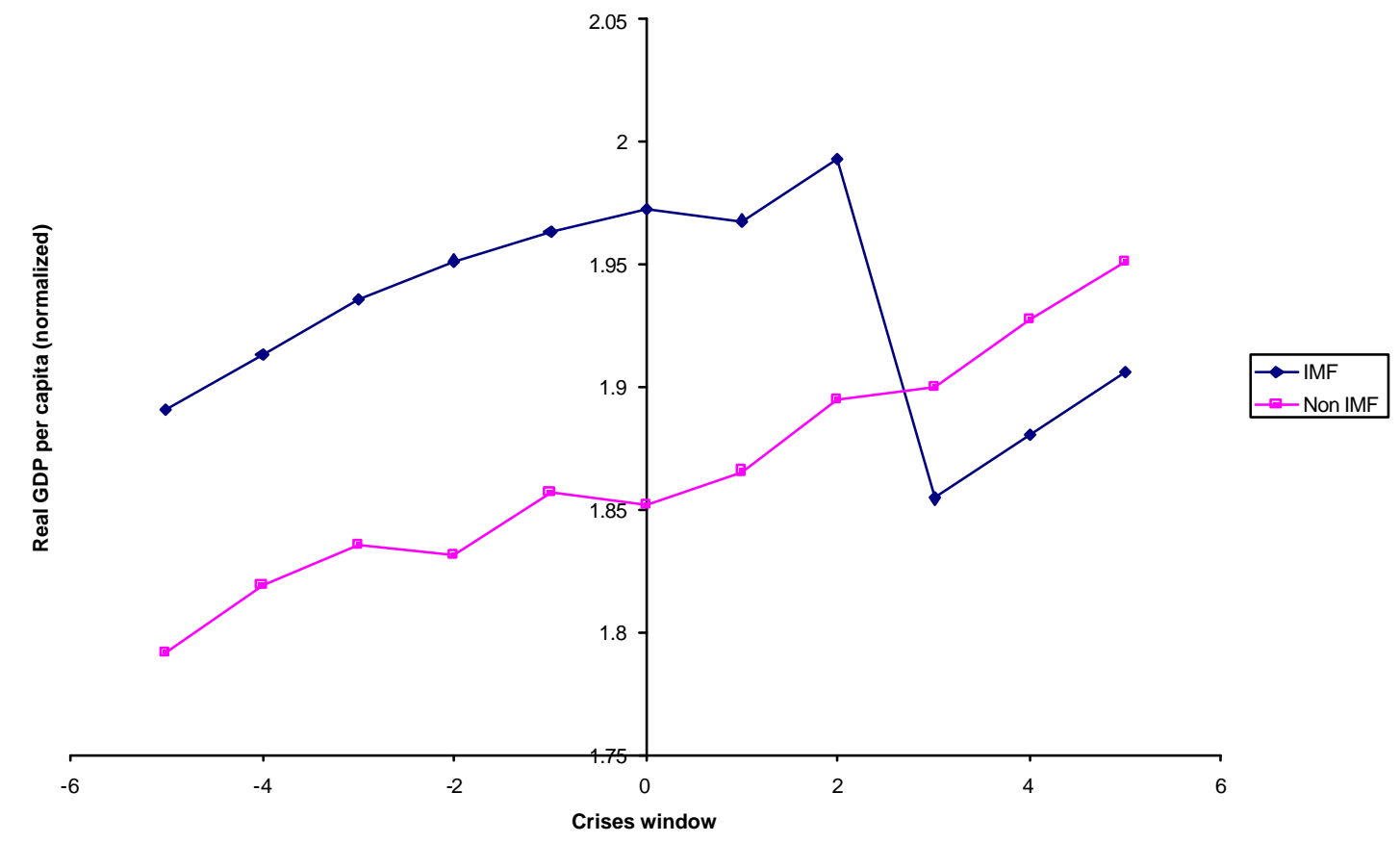




\section{Figure 4. Consumption}

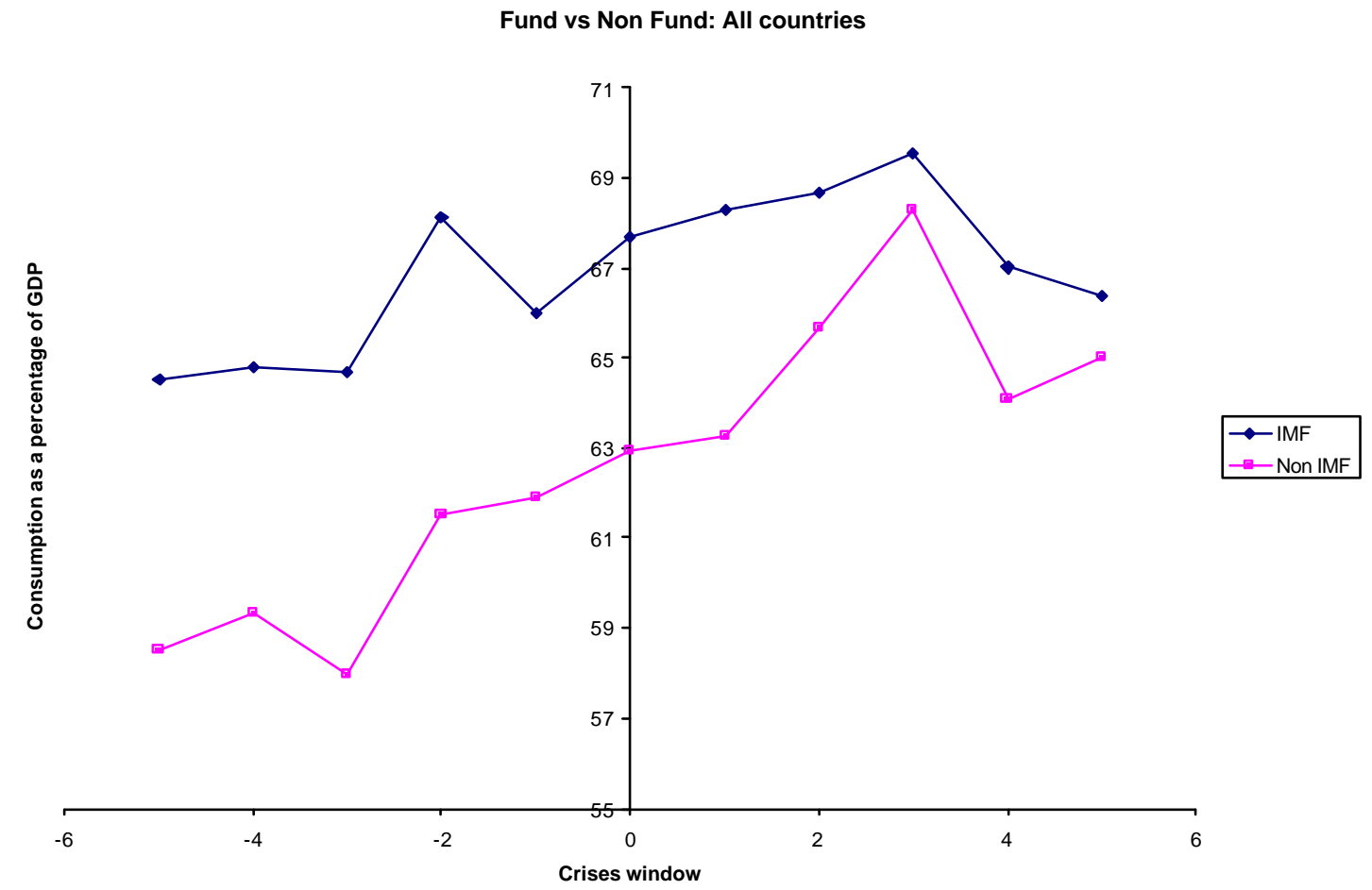

Fund vs Non Fund: Latin America

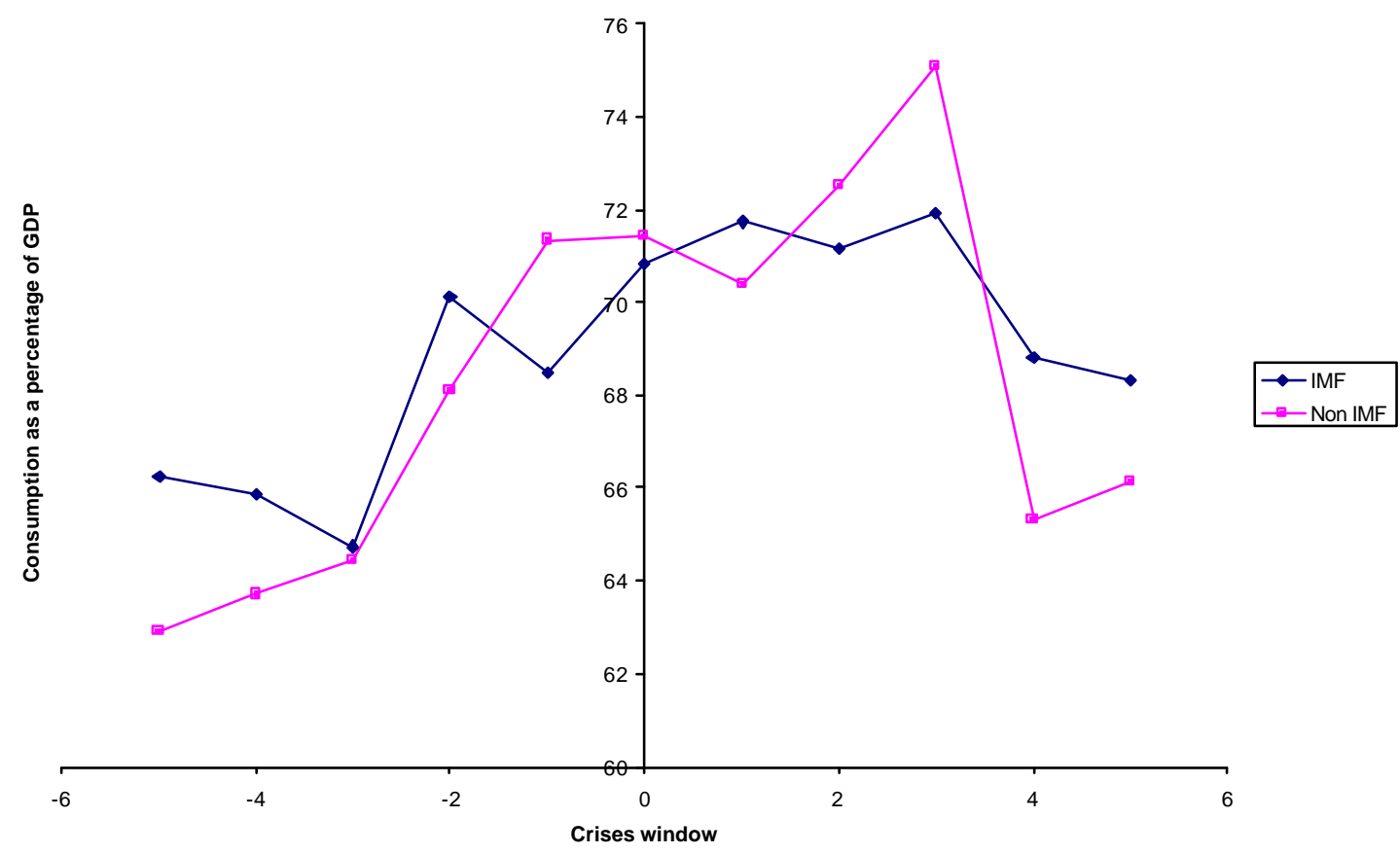




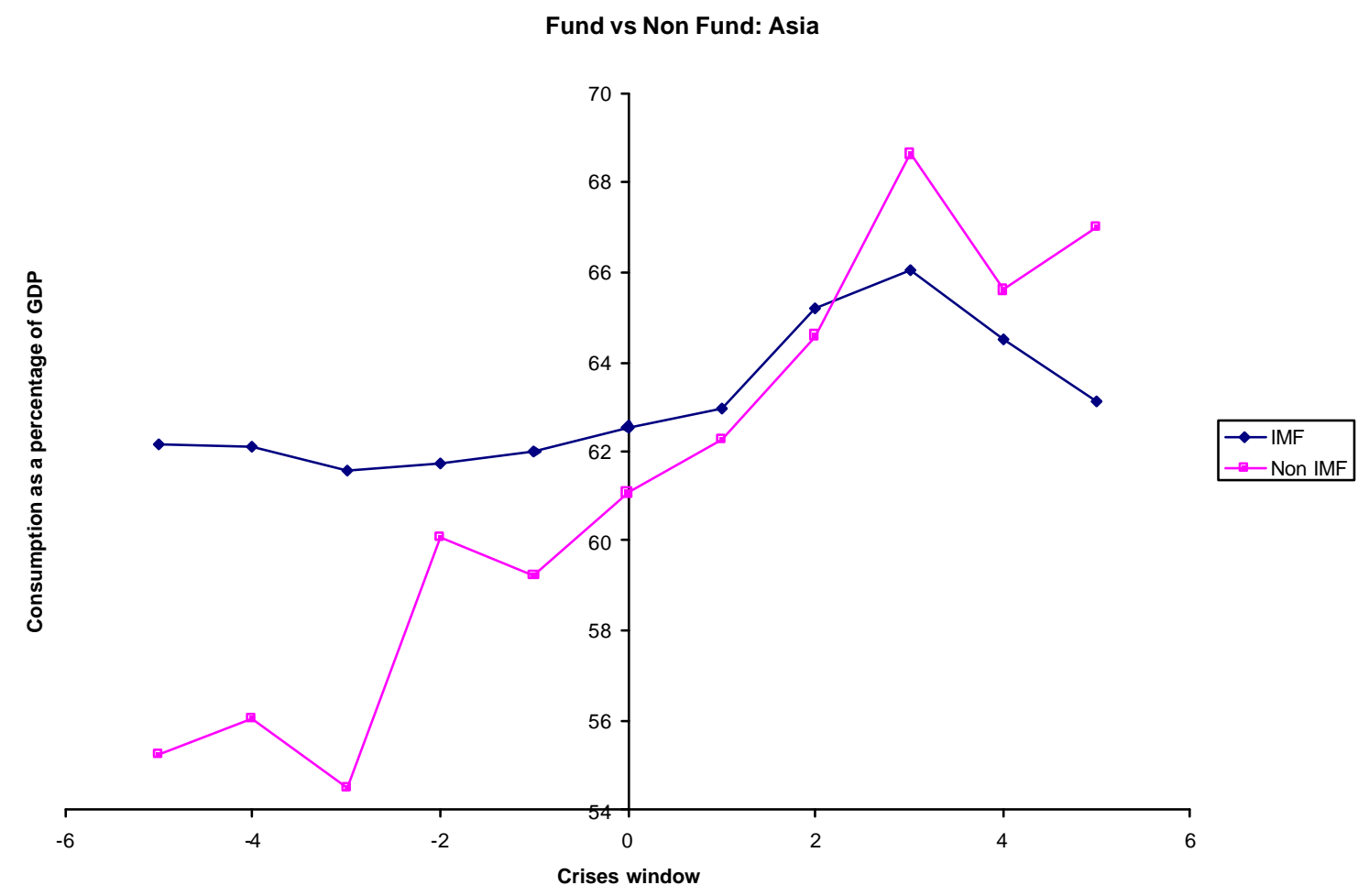

Figure 5. Current Account as a percentage of GDP

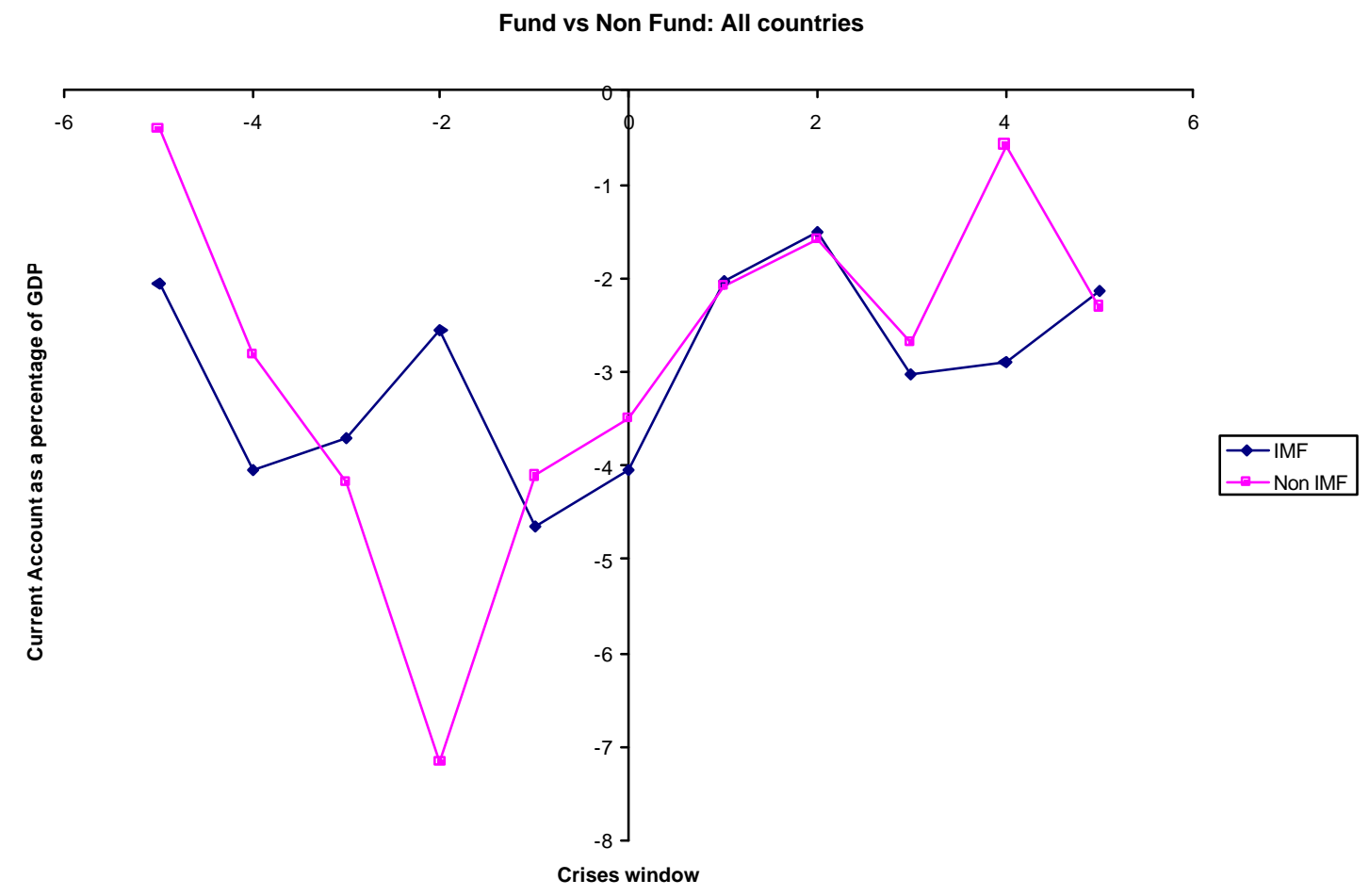


Fund vs Non Fund: Latin America

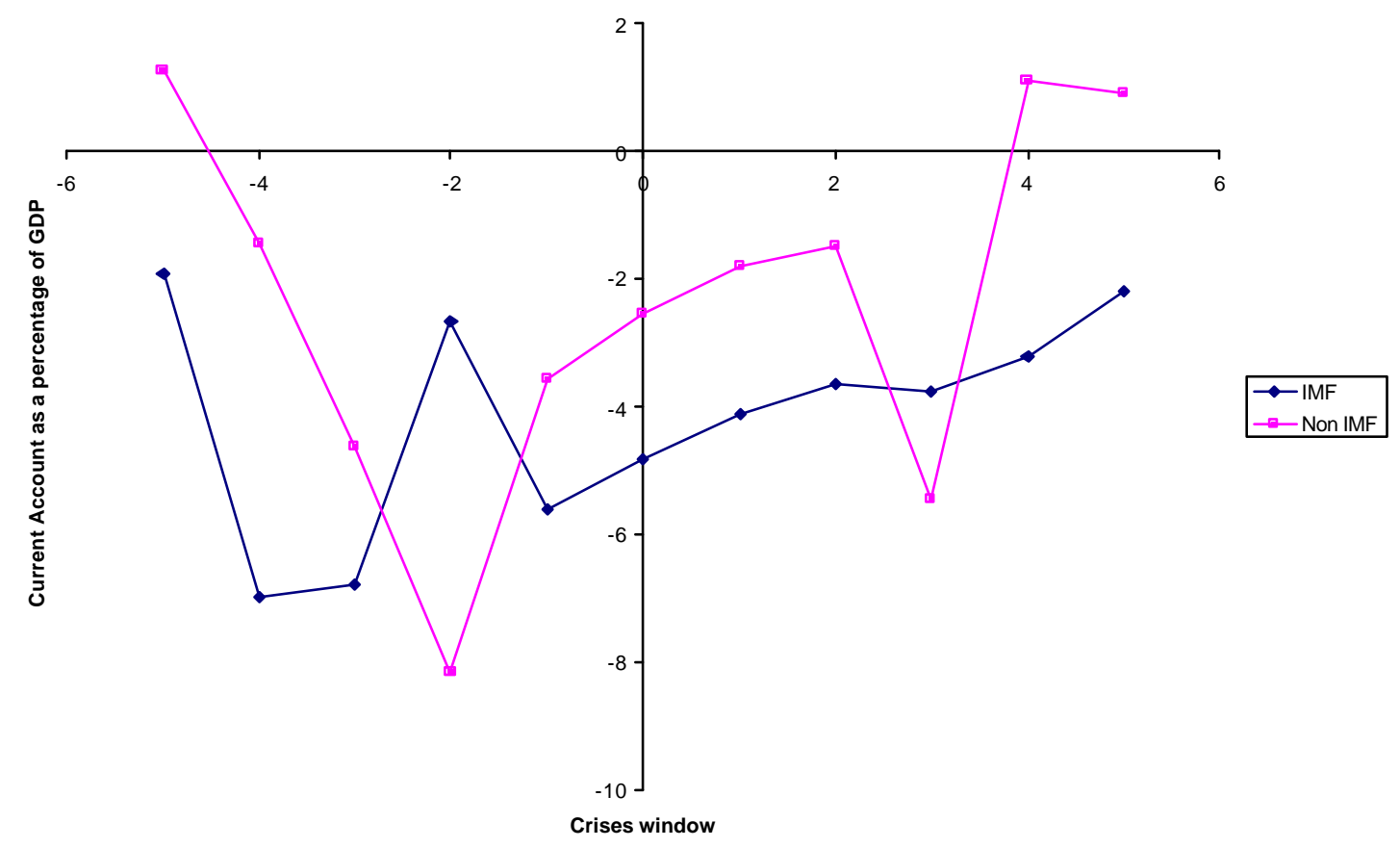

Fund vs Non Fund: Asia

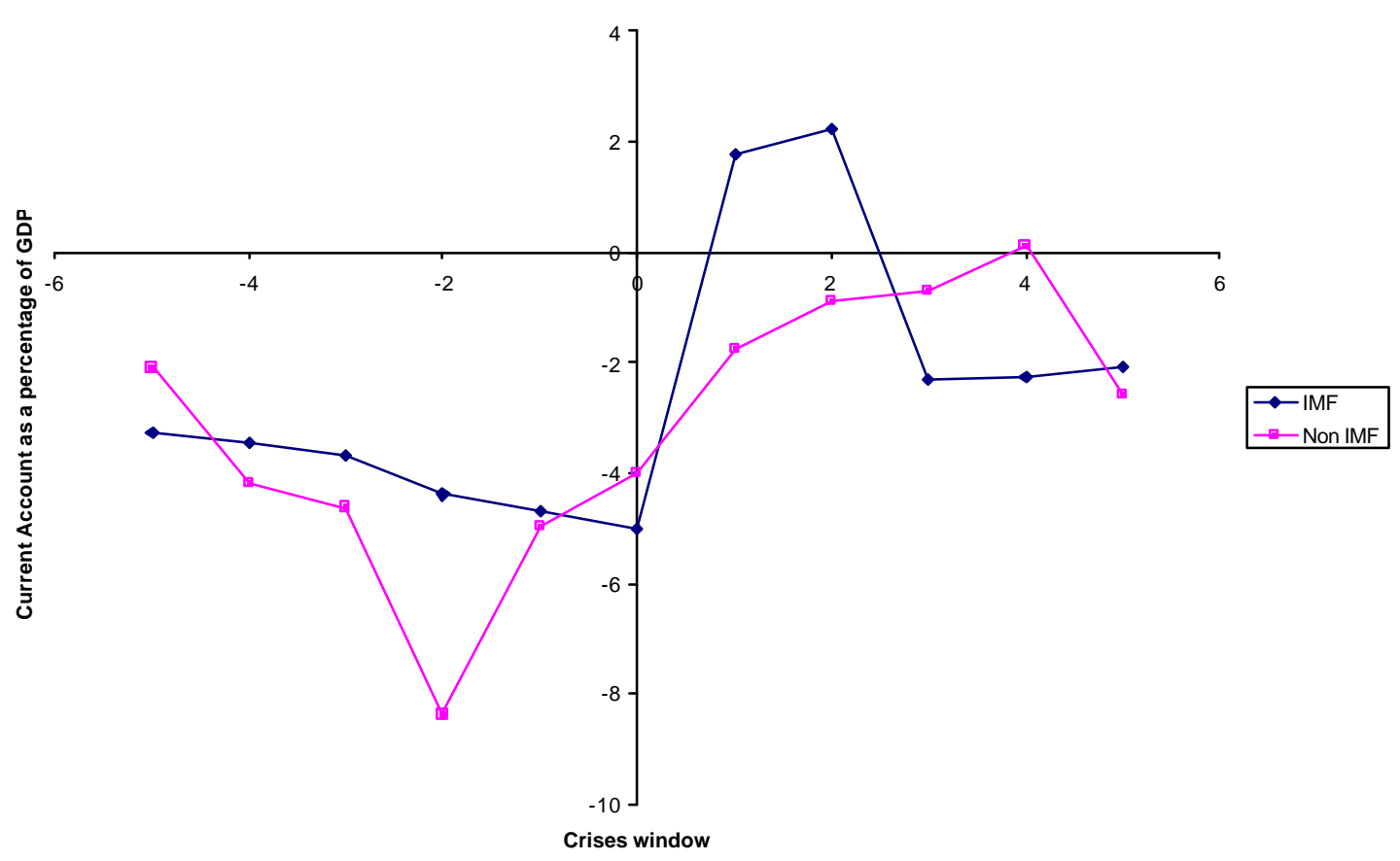




\section{Figure 6. Inflation Rate}

Fund vs Non Fund: All countries

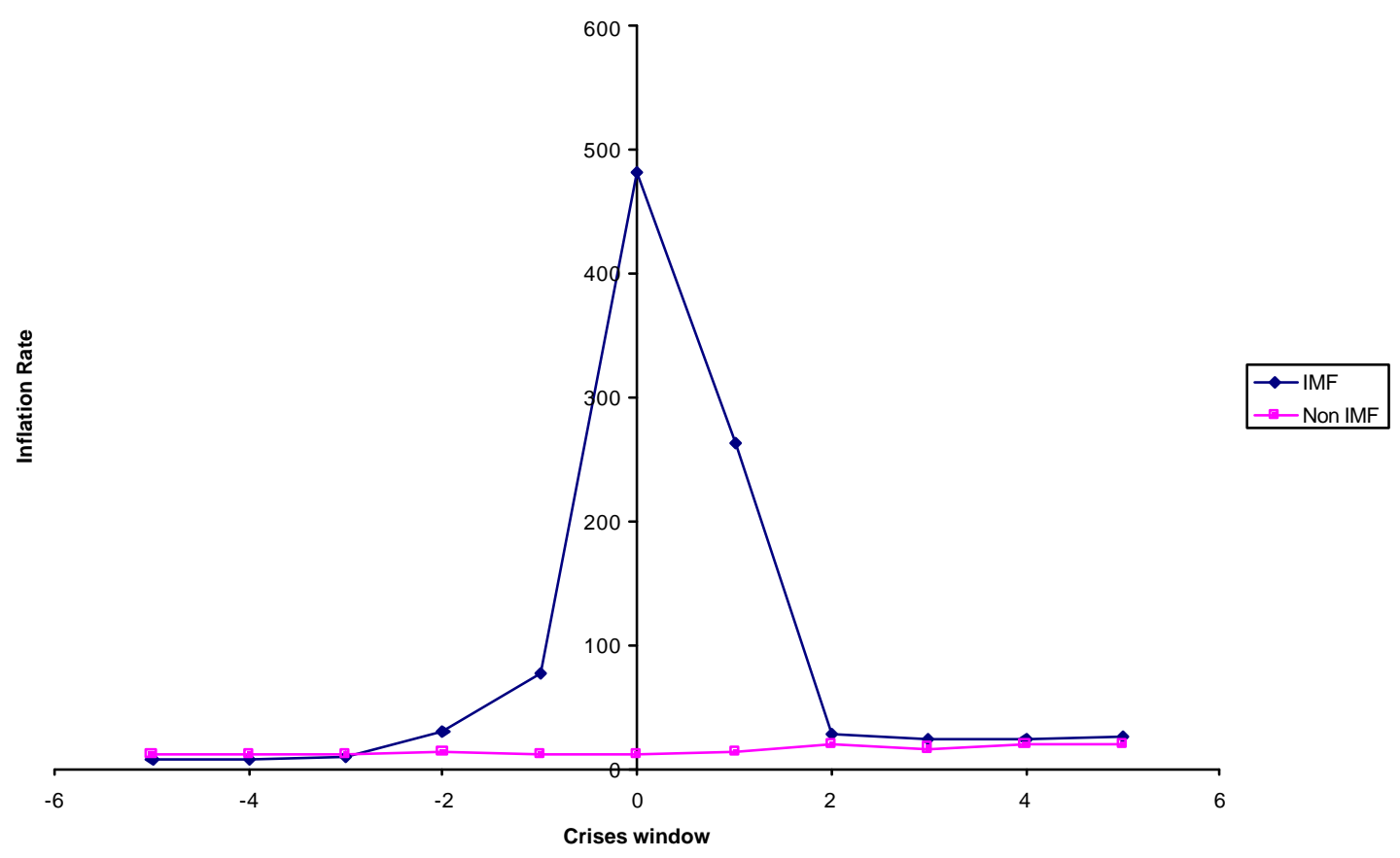

Fund vs Non Fund: Latin America

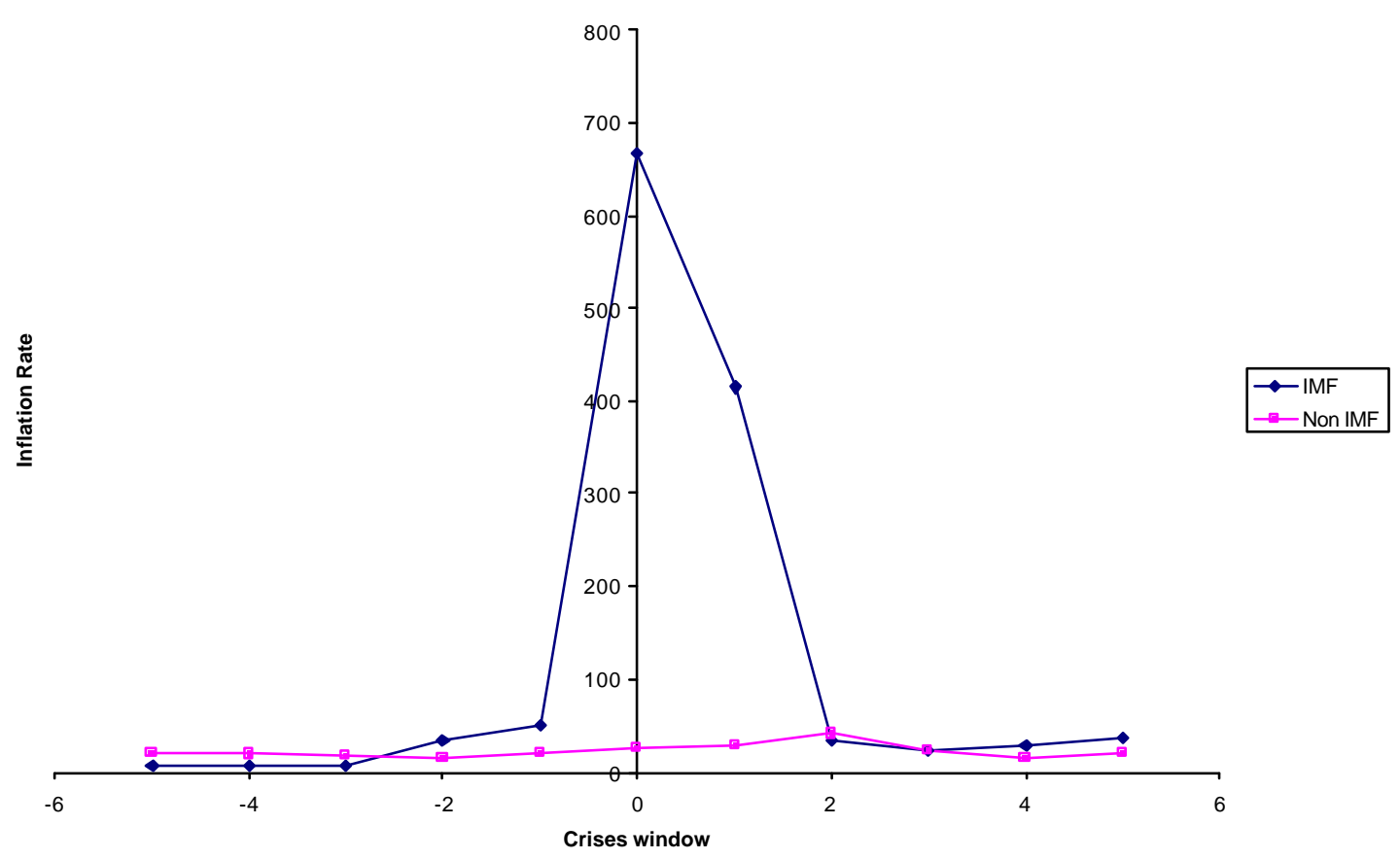




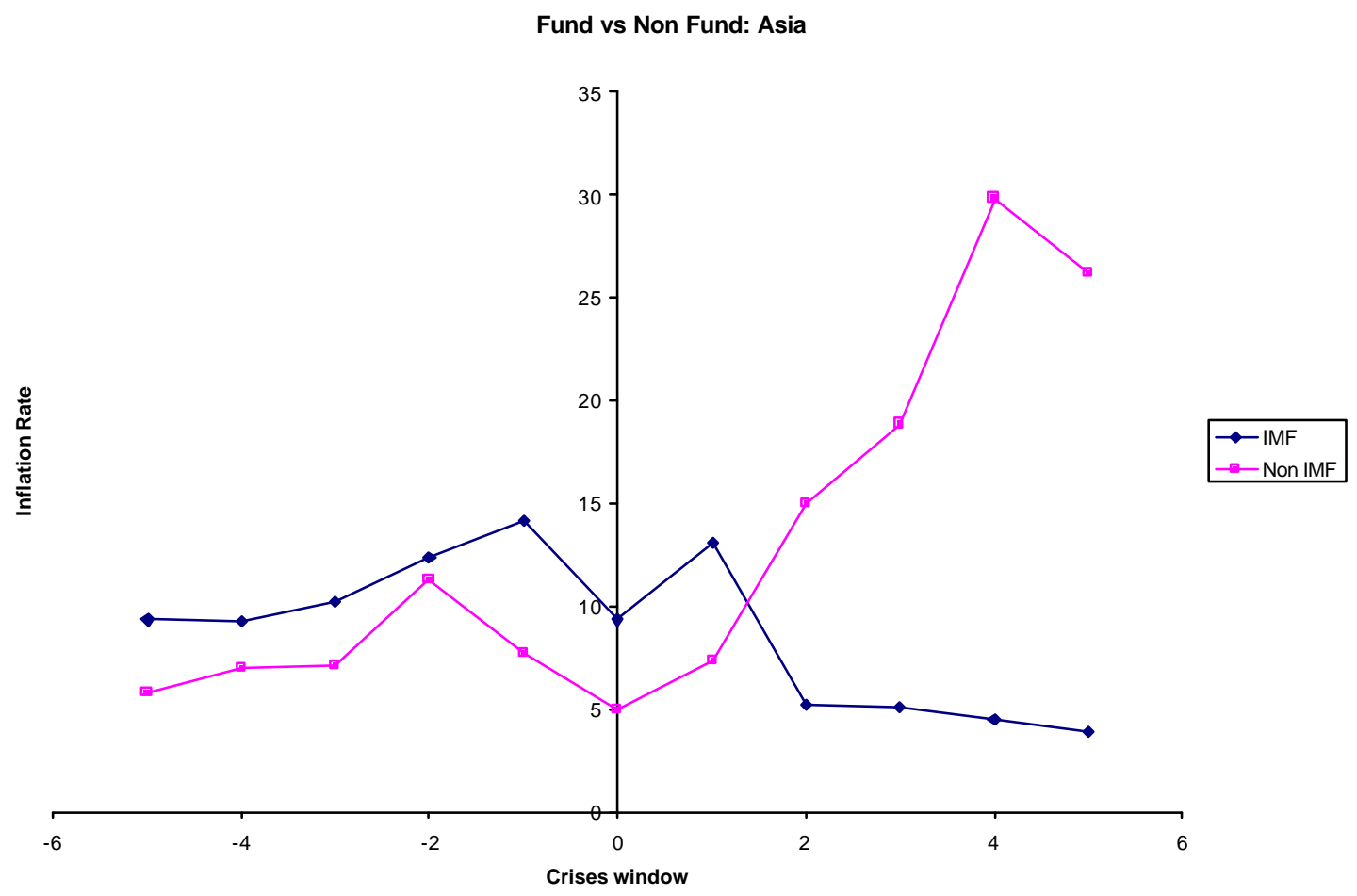

Figure 7. Money Growth

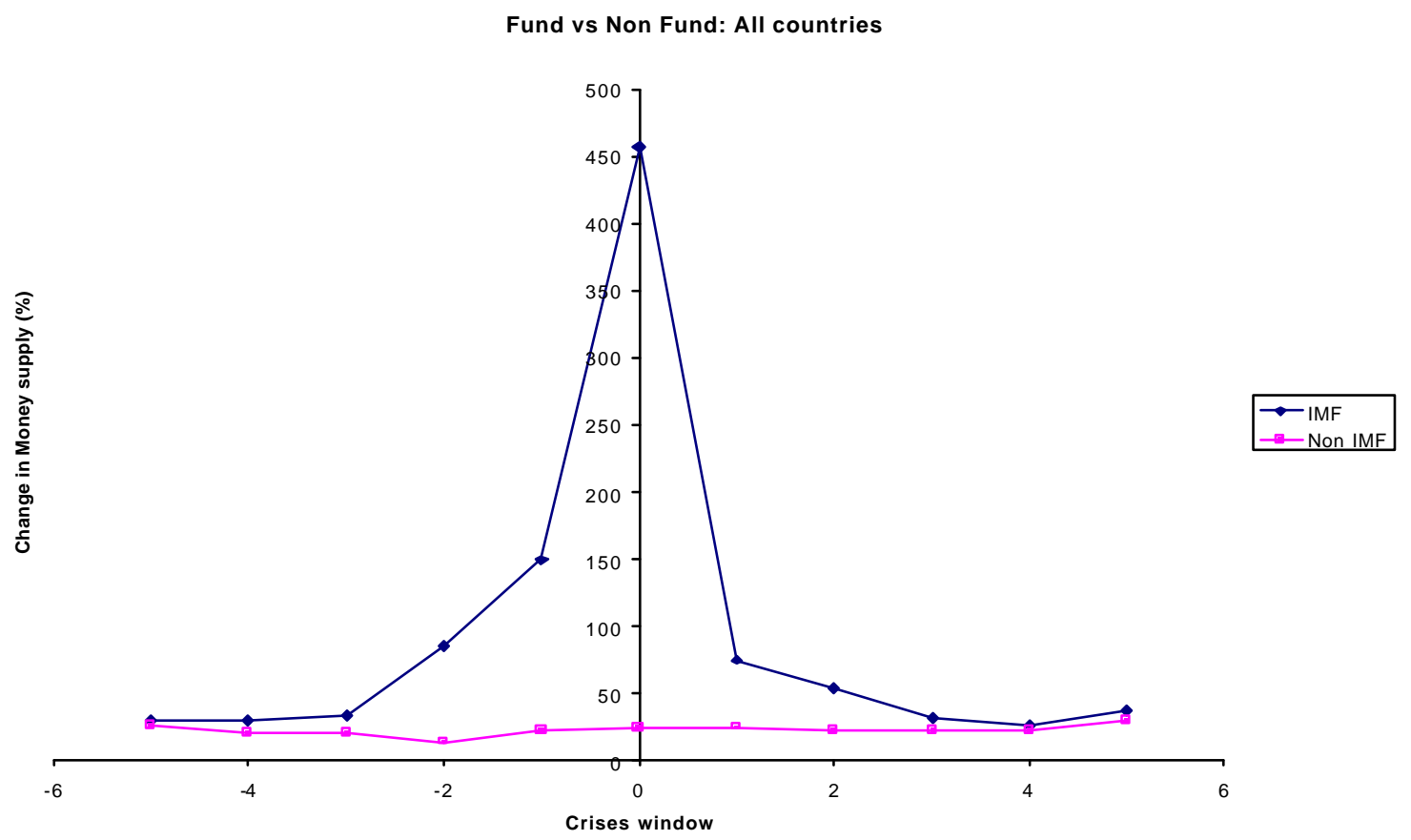




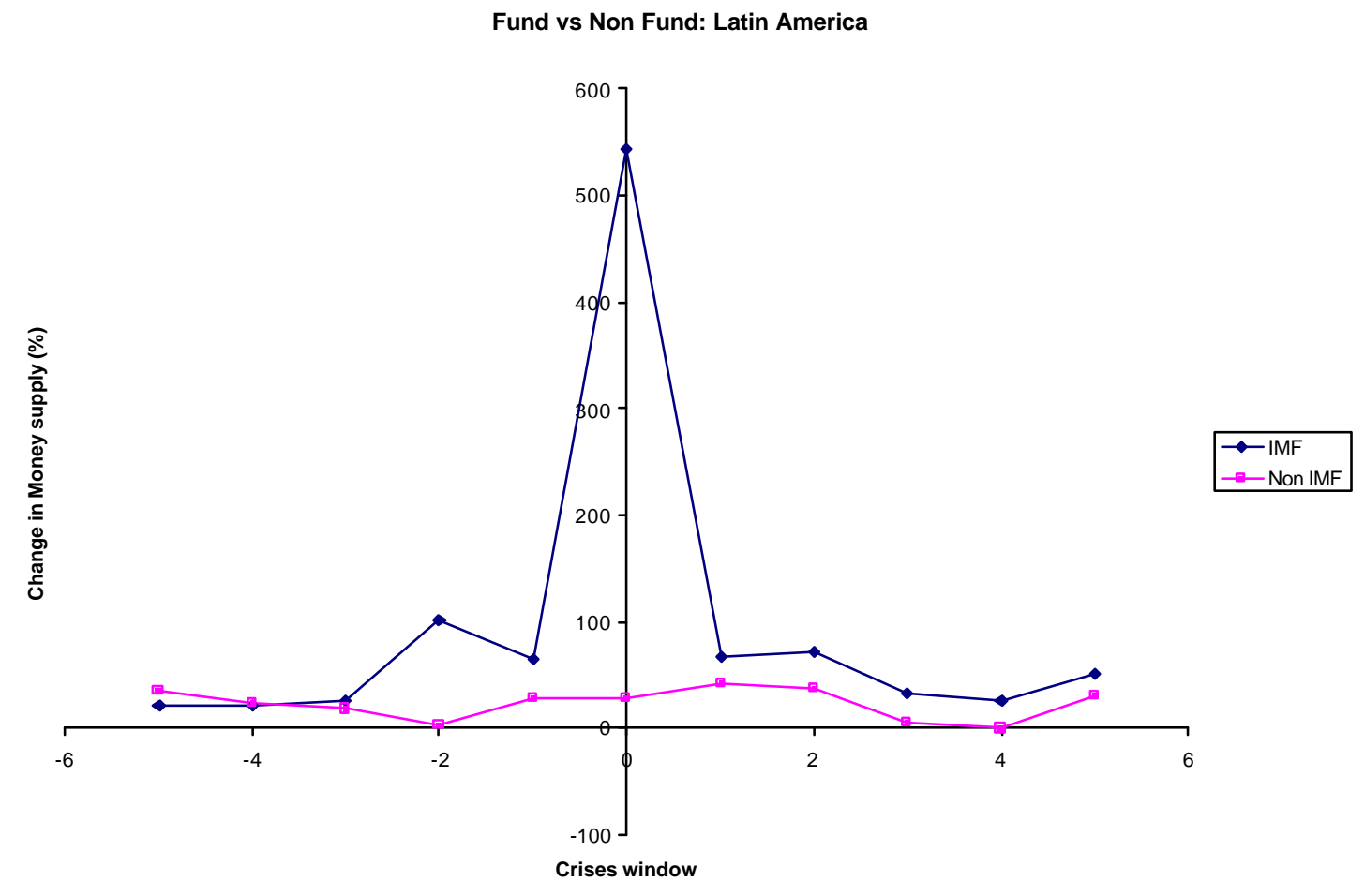

Fund vs Non Fund: Asia

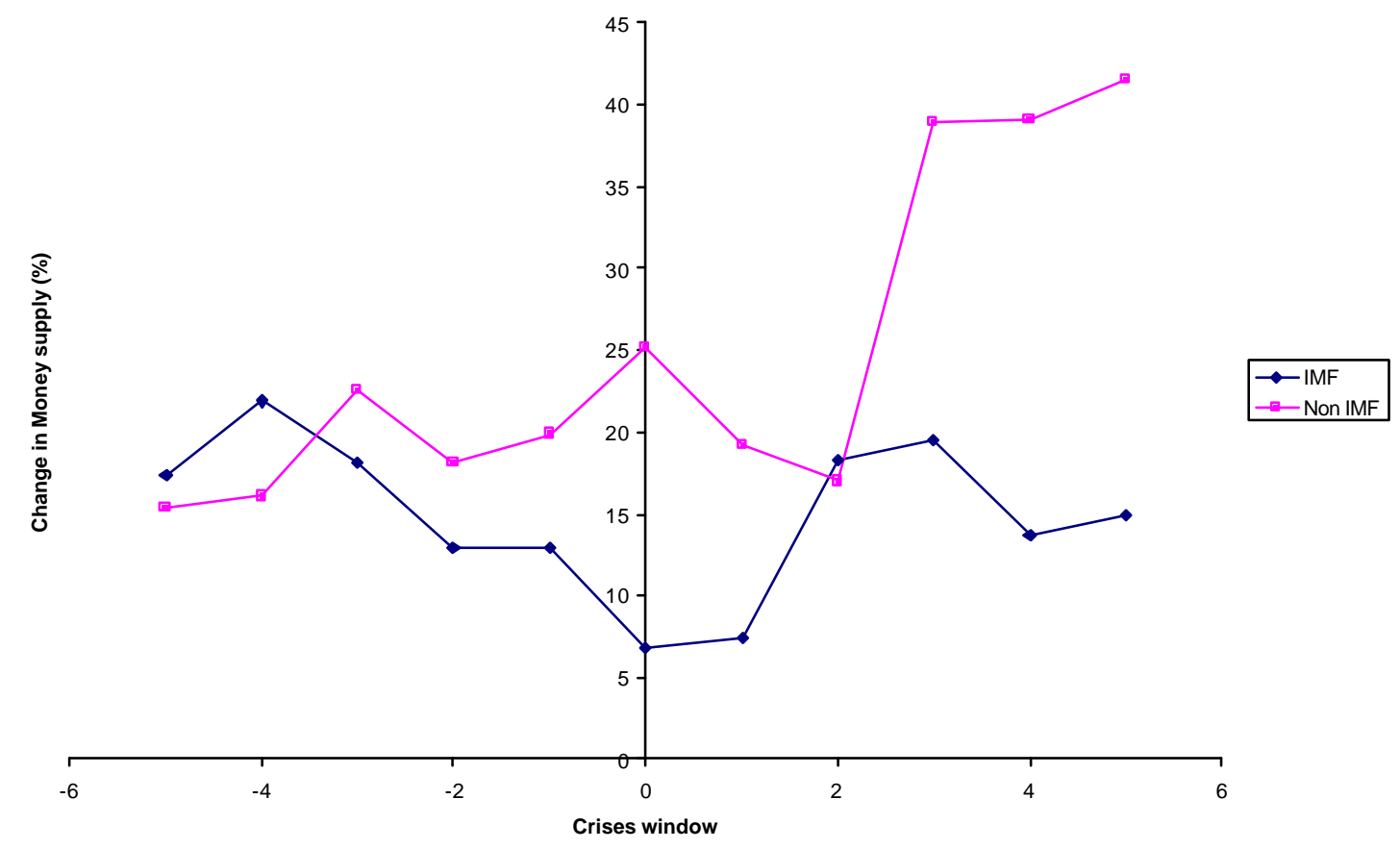




\section{Figure 8. Budget Deficit}

Fund vs Non Fund: All countries

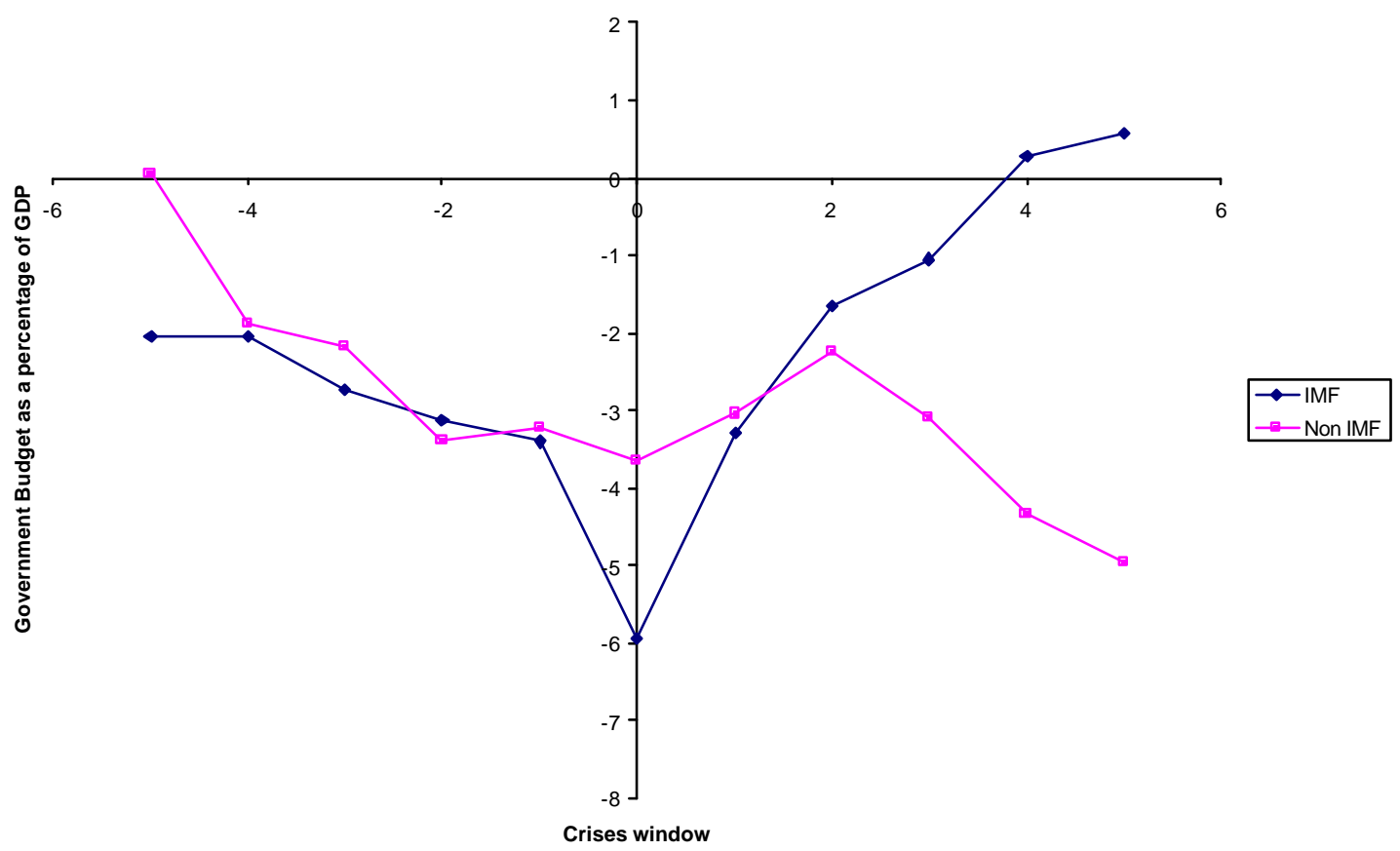

Fund vs Non Fund: Latin America

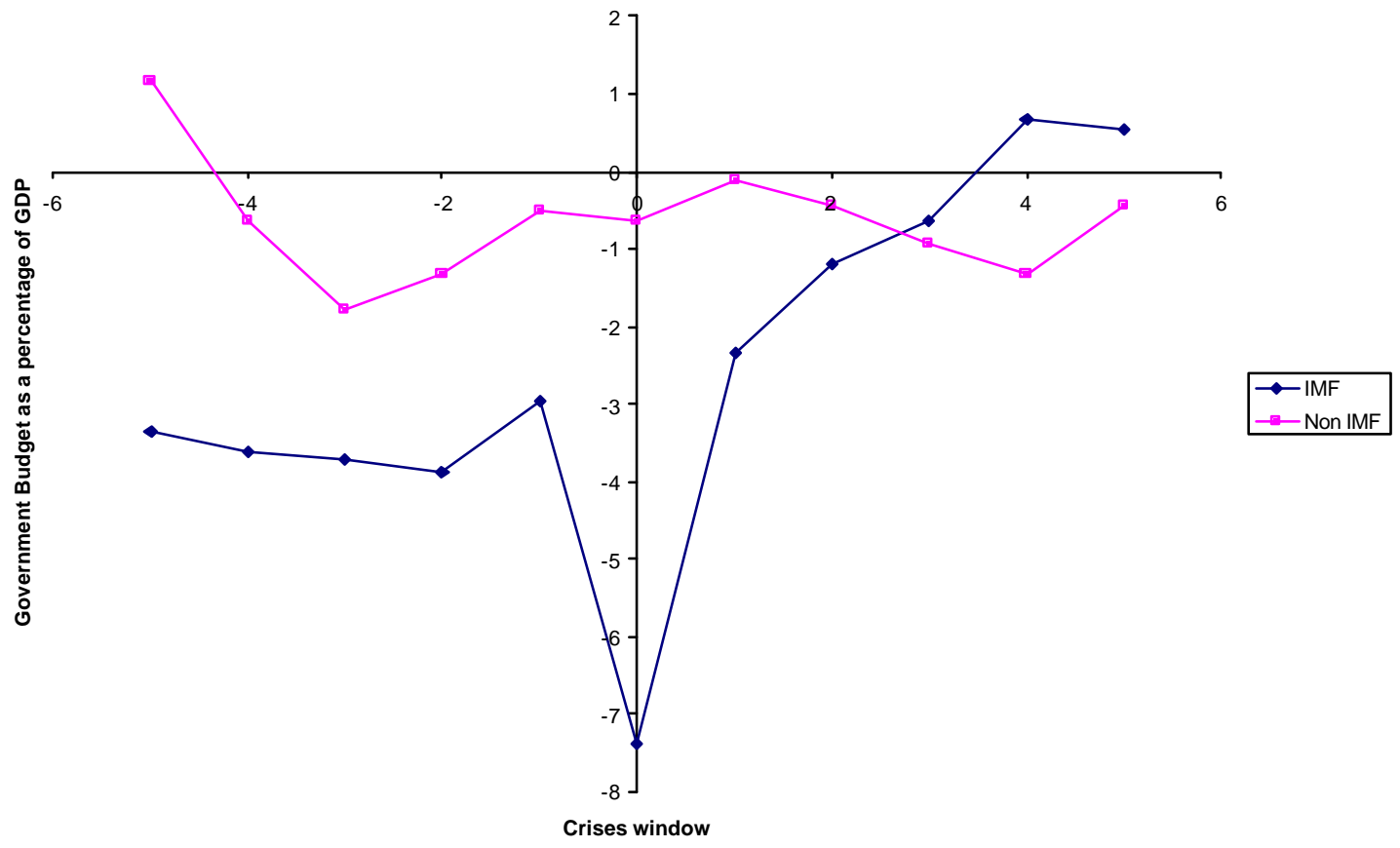


Fund vs Non Fund: Asia

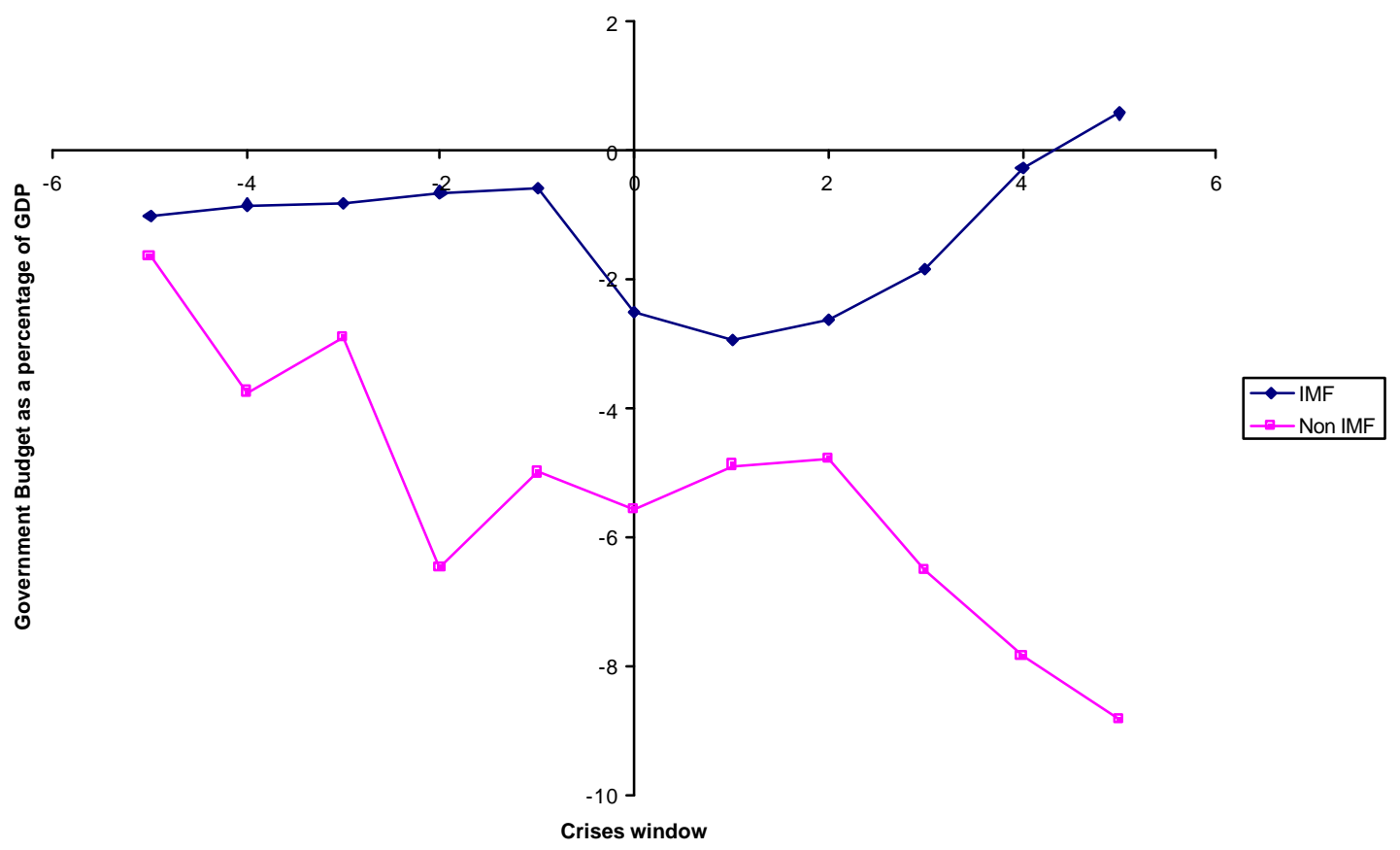

Figure 9. Nominal Interest rates

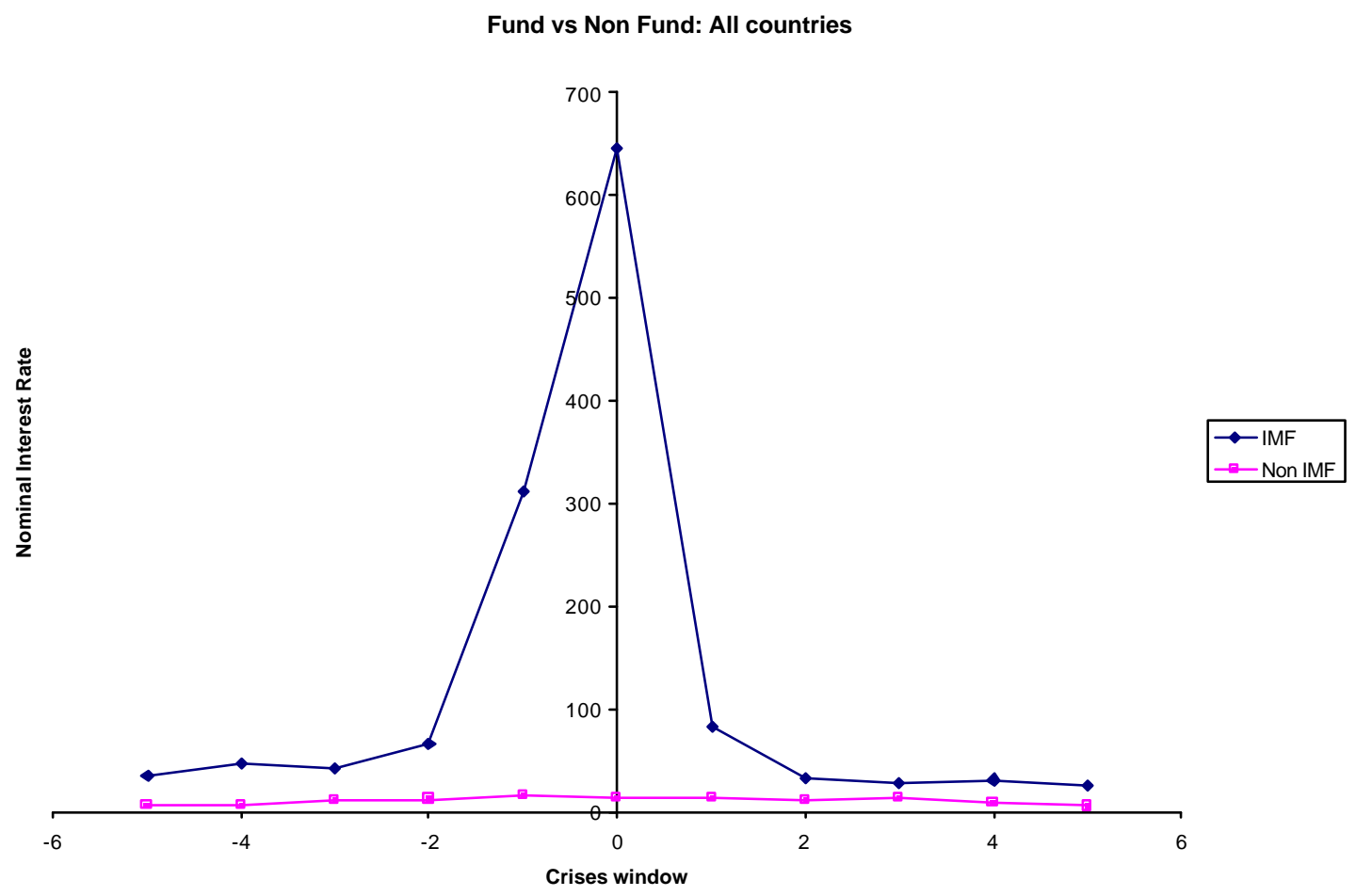




\section{Fund vs Non Fund: Latin America}

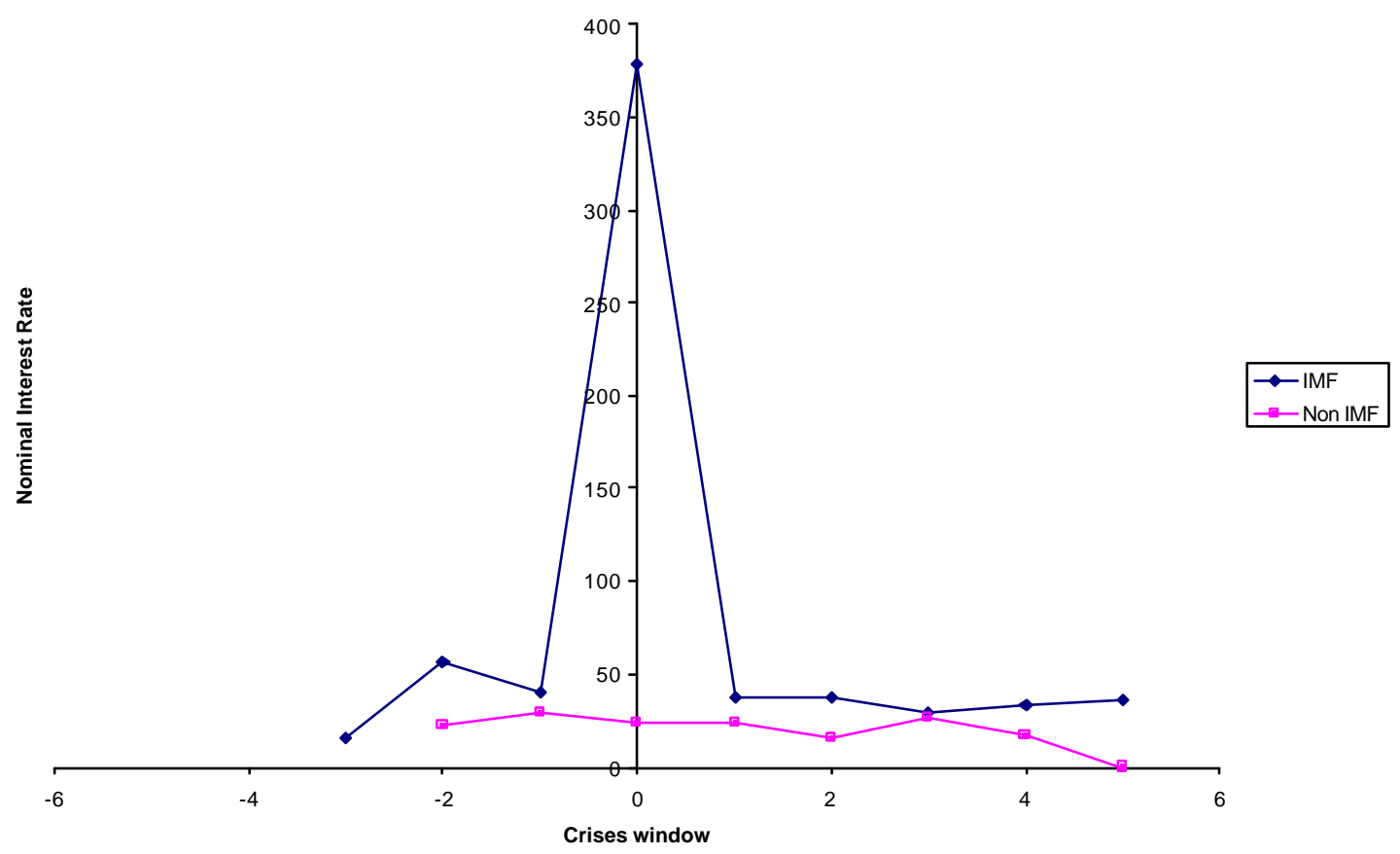

Fund vs Non Fund: Asia

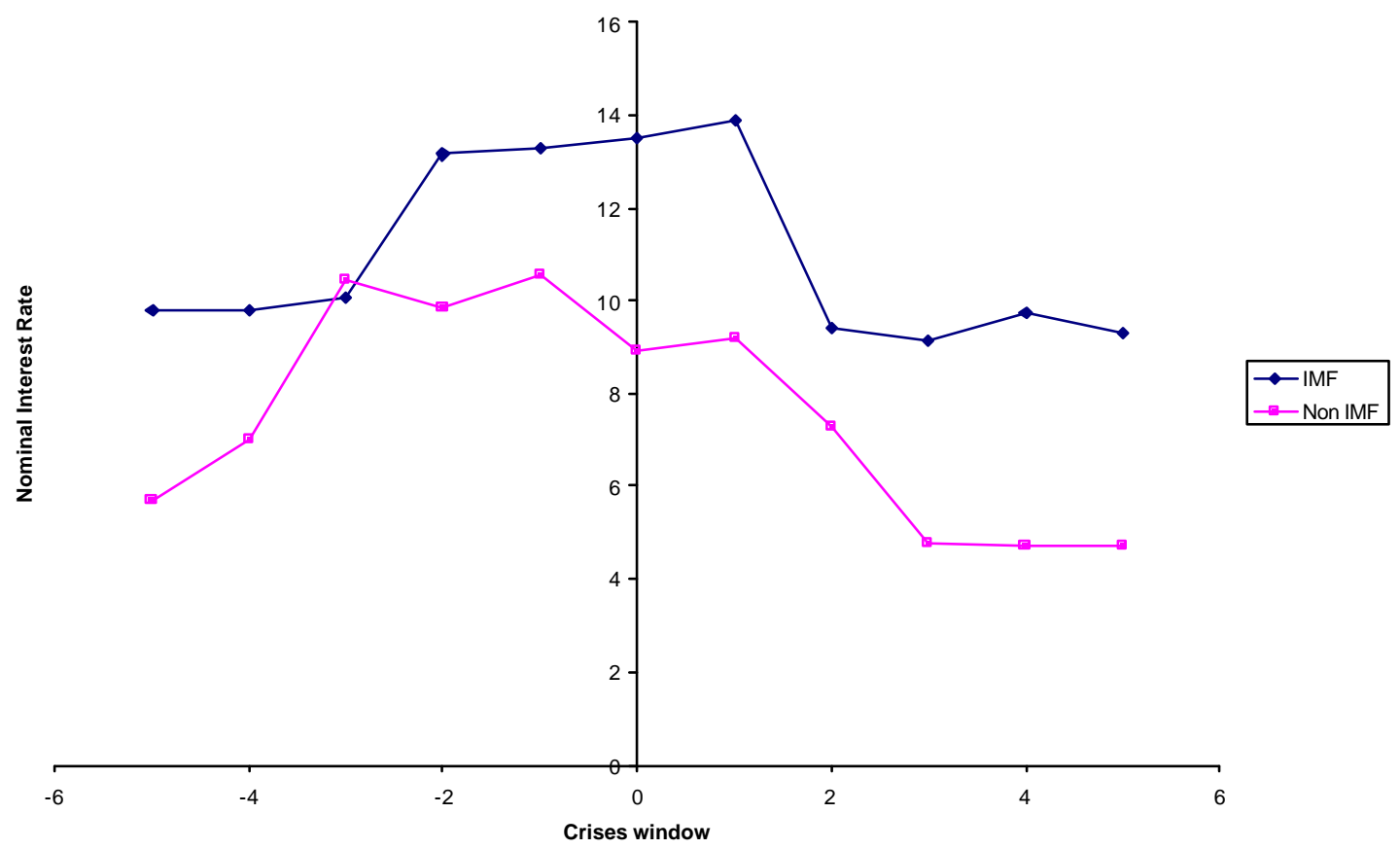




\section{Figure 10. Nominal Exchange Rates}
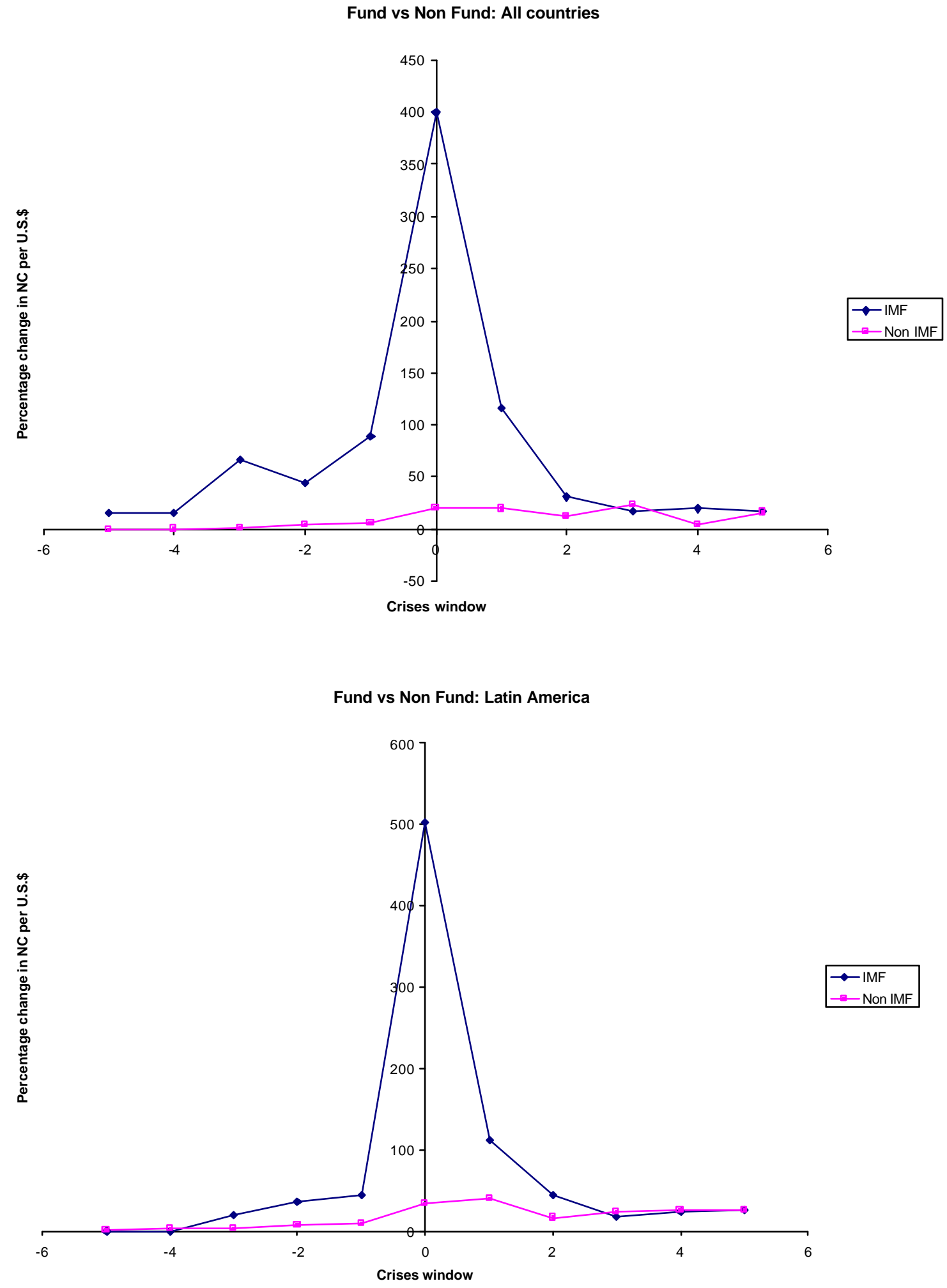


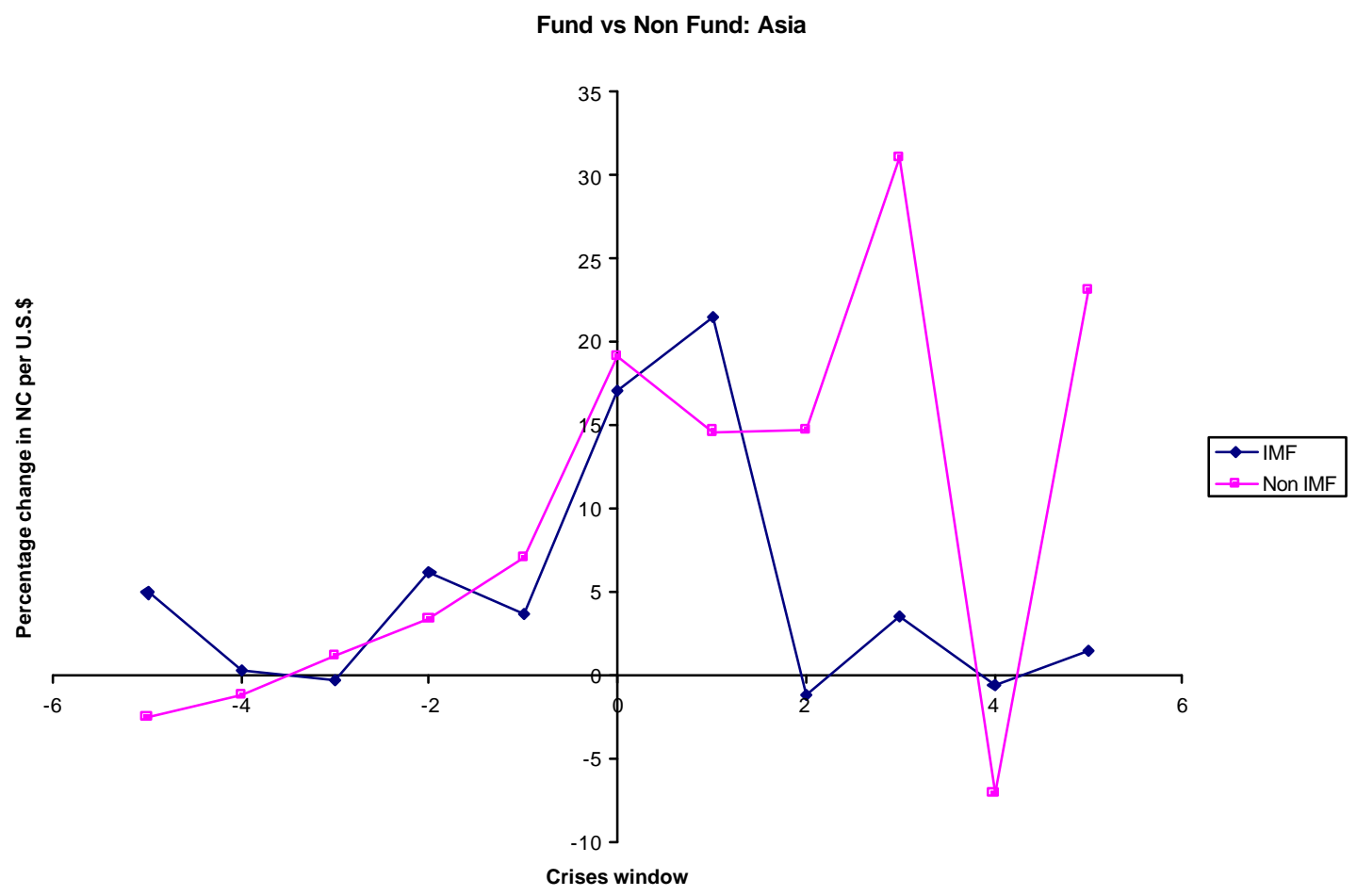

Figure 11. Real Exchange Rates

Fund vs Non Fund: All countries

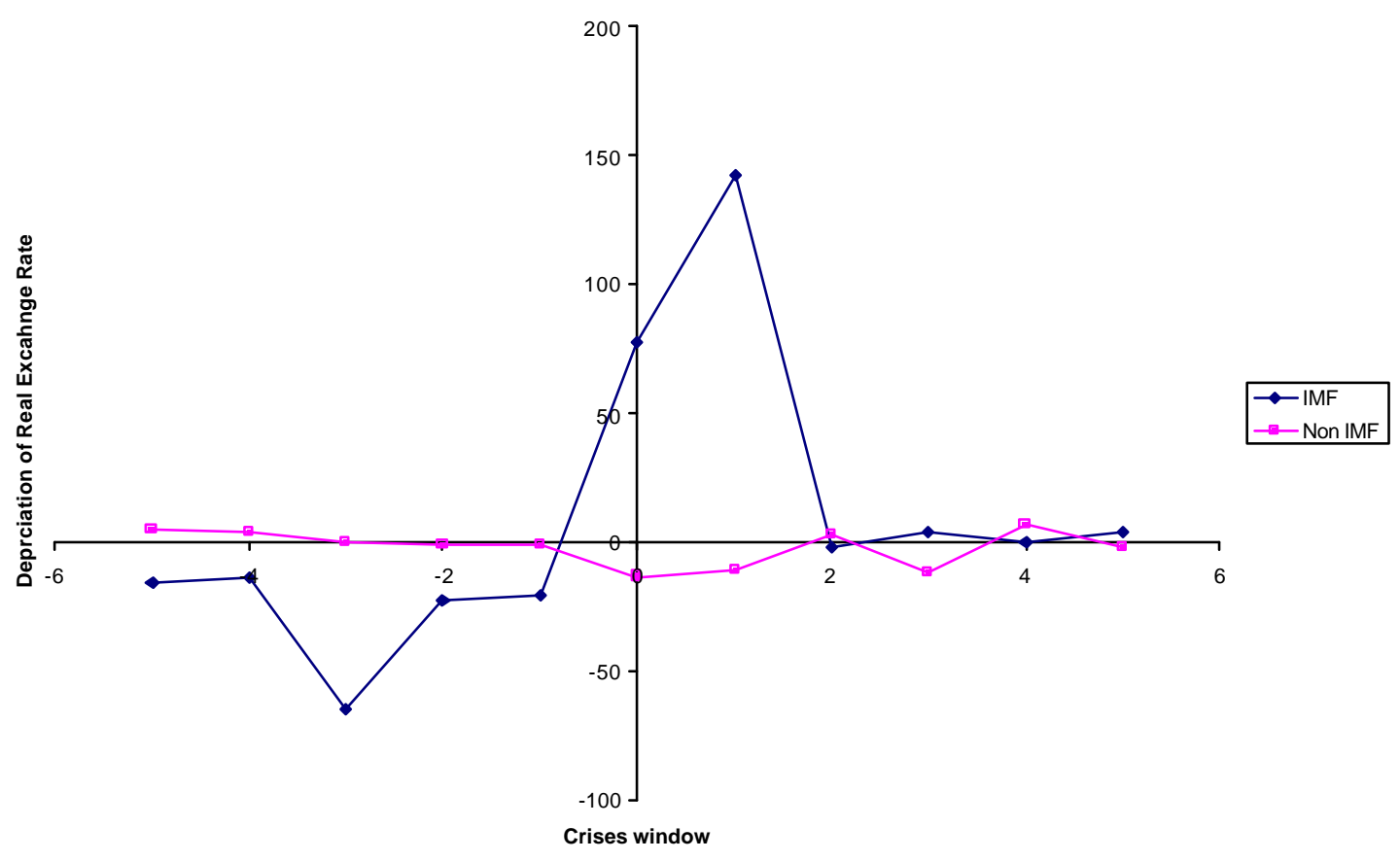




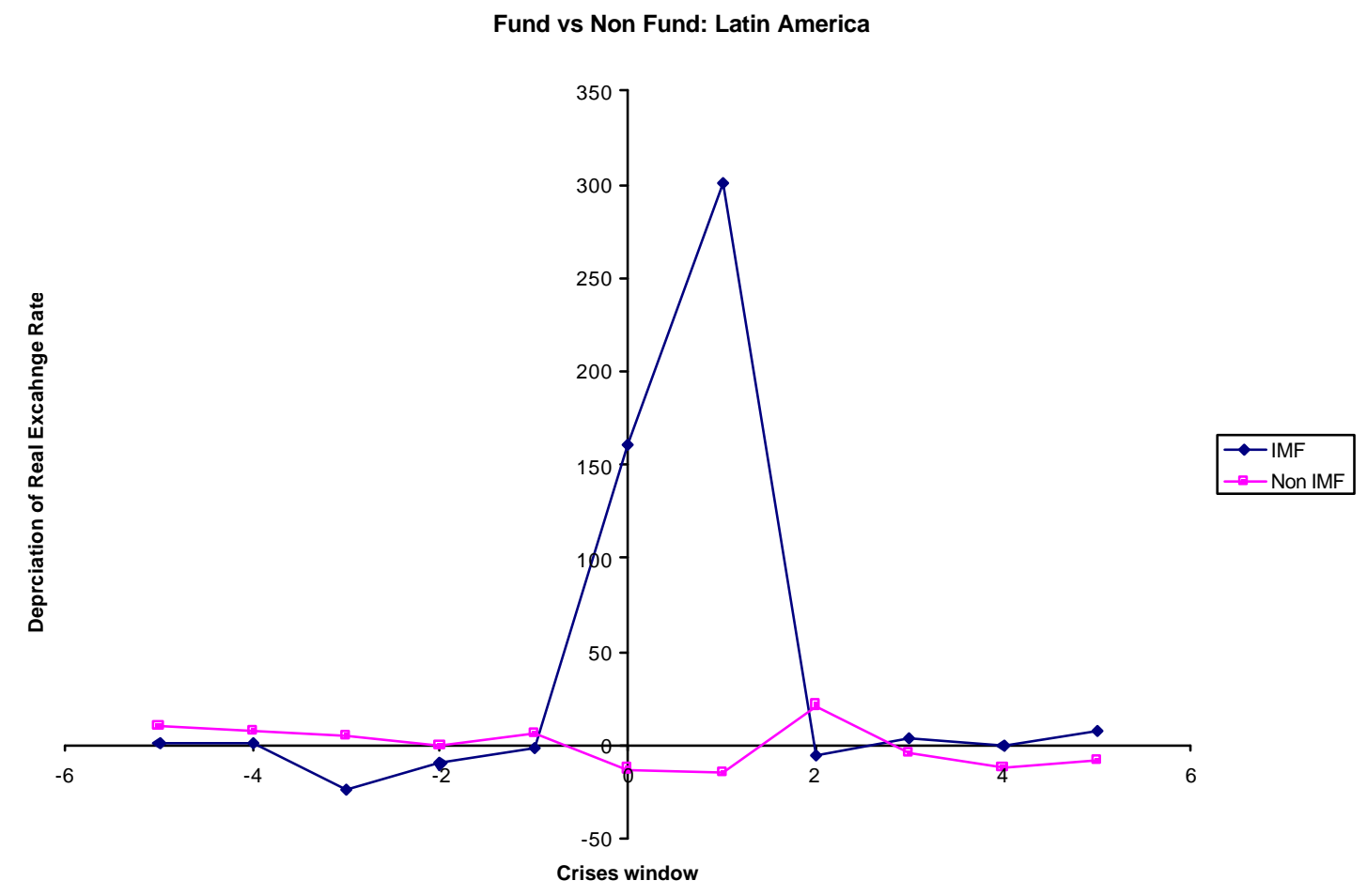

Fund vs Non Fund: Asia

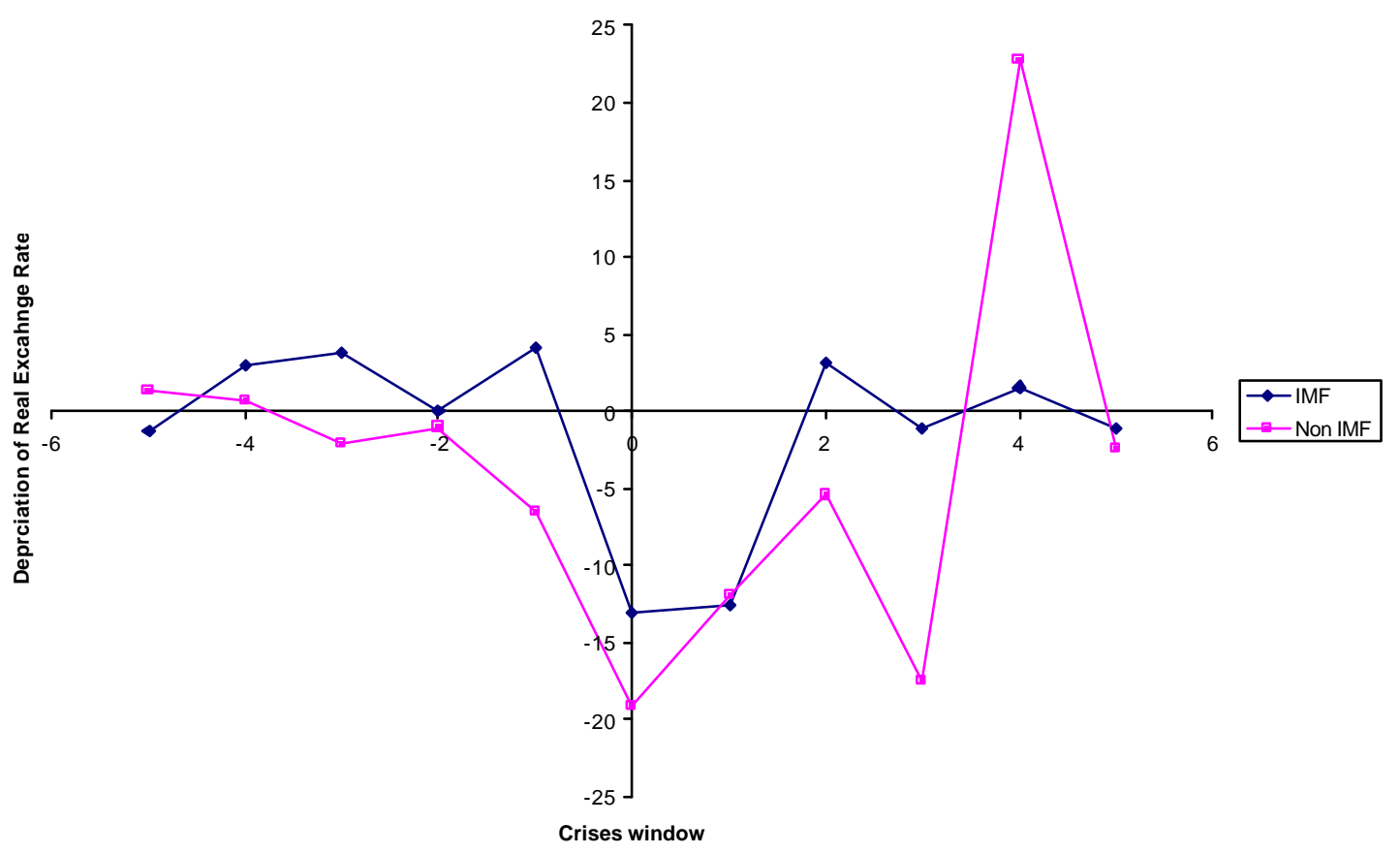




\section{Data Appendix}

All variables except for the term structure of foreign debt are available in International Financial Statistics (IFS), International Monetary Fund. The series on short-term foreign debt is available in The Maturity, Sectoral, and Nationality Distribution of International Bank Lending, Bank for International Settlements (BIS).

For the quarterly data with missing observations we interpolated nominal GDP and the current account by making the growth rate uniform over four quarters. To derive real GDP we normalized nominal GDP by the consumer price index. Quarterly short-term debt was interpolated along a straight line from semi-annual data. 